متطلبات أداء مقطوعات البيانو في أستراليا عند روي أجنيو Roy Agnew

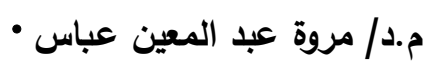

\title{
مقدمه البحث:
}

تأثرت الموسيقي الأسترالية بالموسيقي الثعبية وقوالب التأليف الكلاسيكية الأوروبية والأمريكية،

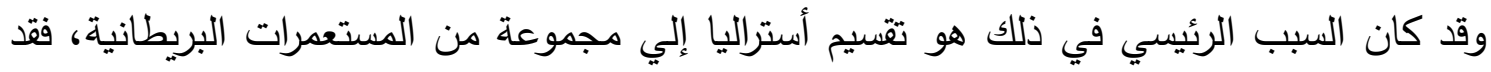

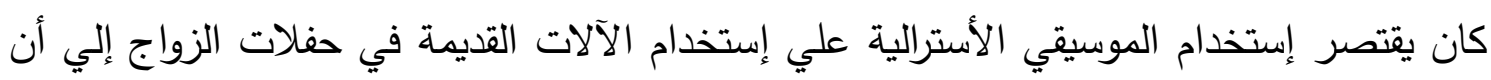

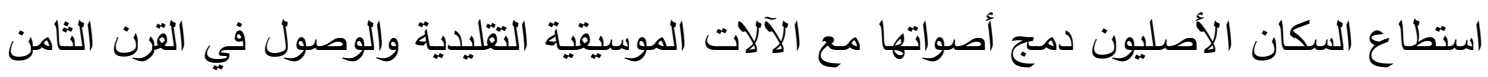

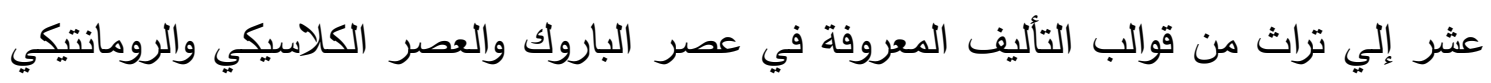
والموسيقي المعاصرة . بدأ المؤلفون الإستراليون في نهاية القرن الثامن عشر في الظهور نتيجة لبحثهم عن فرص للبحث

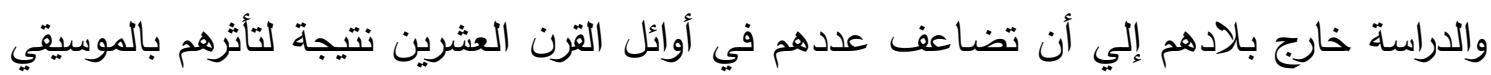
الأوروبية بثكل كبير ، واتجه الموسيقيون والمؤلفون مع زيادة الوعي الوطني القومي إلي إستخدام

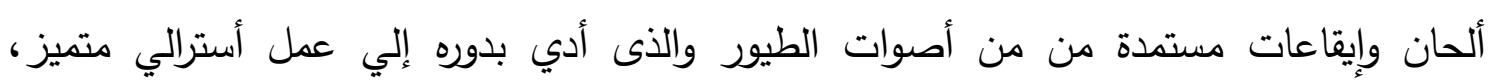

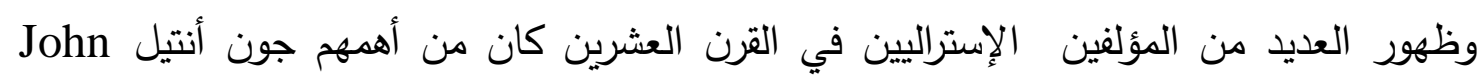
Antil

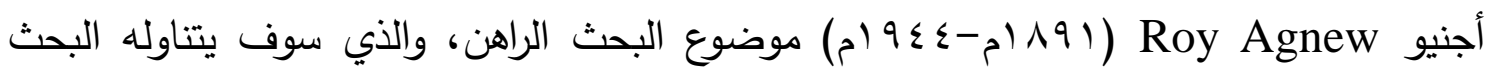

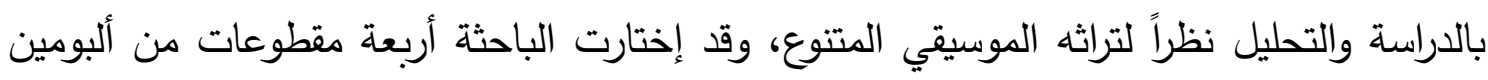

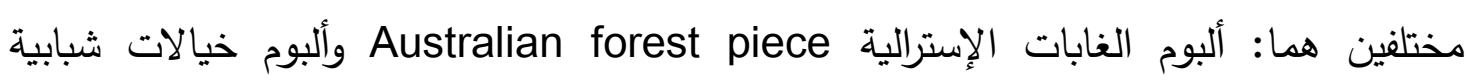
Youthful fancies مثكلة البحث

تحتوي مقطوعات البيانو الإسترالية علي العديد من التقنيات الآدائية والعزفية المتتوعة،

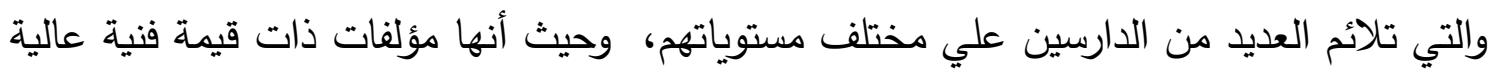

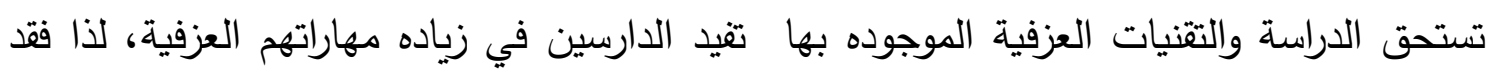

• مدرس دكتور بقسم البيانو - كلية التربية الموسيقية - جامعة حلوان.

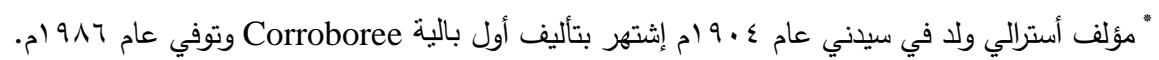

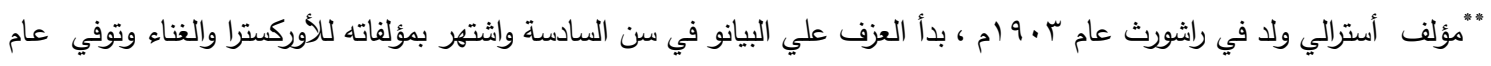

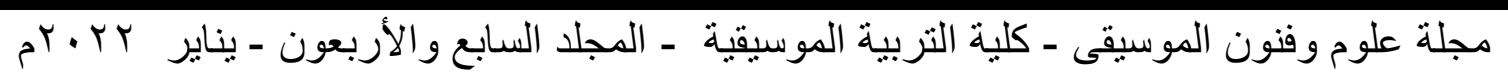


رأت الباحثة تناول مقطوعات البيانو عند روي أجنيو بإعتباره من أهم مؤلفي الموسيقى الإسترالية

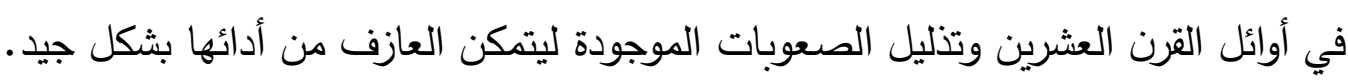

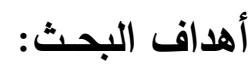

1- التعرف علي سمات وخصائص الموسيقى الاسترالية . r- التعرف علي السيرة الذاتية للمؤلف روي أجنيو وأهم مؤلفاته.

r- تحديد الصعوبات العزفية في مقطوعات البيانو عند روي اجنيو ومتطلبات آدائها.

ع - تذليل الصعوبات العزفية في مقطوعات البيانو عند روي اجنيو ومتطلبات آدائها.

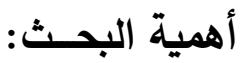

اتاحة الفرص لاختيارات متنوعة لمؤلفات عالمية لبيانو تحتوي على تقنيات عزفية وآدائية تتاسب المستوى العزفي لمستويات عديدة من الطلاب في مراحل مختلفة والوصول إلى منطلبات

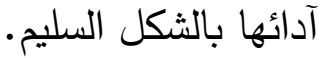

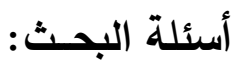

ا - ما هي سمات الموسيقى الإسترالية وأهم مؤلفيها ؟

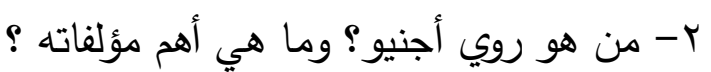

r- ماهي الصعوبات العزفية في مقطوعات البيانو عند روي اجنيو ومتطلبات آدائها. ع- ما هي الإرشادات اللازمة لتذليل الصعوبات العزفية في مقطوعات البيانو عند روي اجنيو

$$
\text { أ- أسراءات البحث: منهج البحث: آدائها. }
$$

يتبع البحث المنهج الوصفي "تحليل المحتوى"، وهو المنهج الذي يقوم على وصف الظاهرة

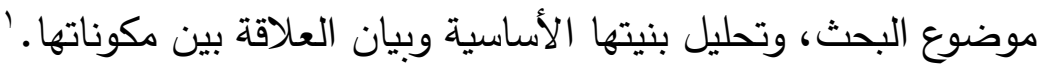

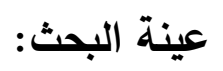

؛ مقطوعات للبيانو من ألبومين مختلفين للمؤلف روي أجنيو وهما:

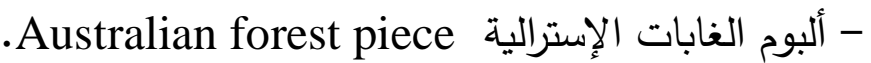
- ألبوم خيالات شبابية Youthful fancies 
وقد راعت الباحثة في إختيار العينة أن تكون المقطوعات متتوعة التقنيات الأدائية والمستوى

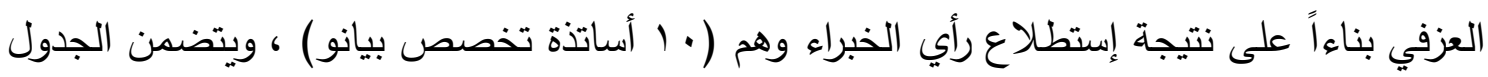
التالي رقم (1) العينة المختارة :

جدول رقم (1)

عينة البحث وهي عبارة عن ع مقطوعات

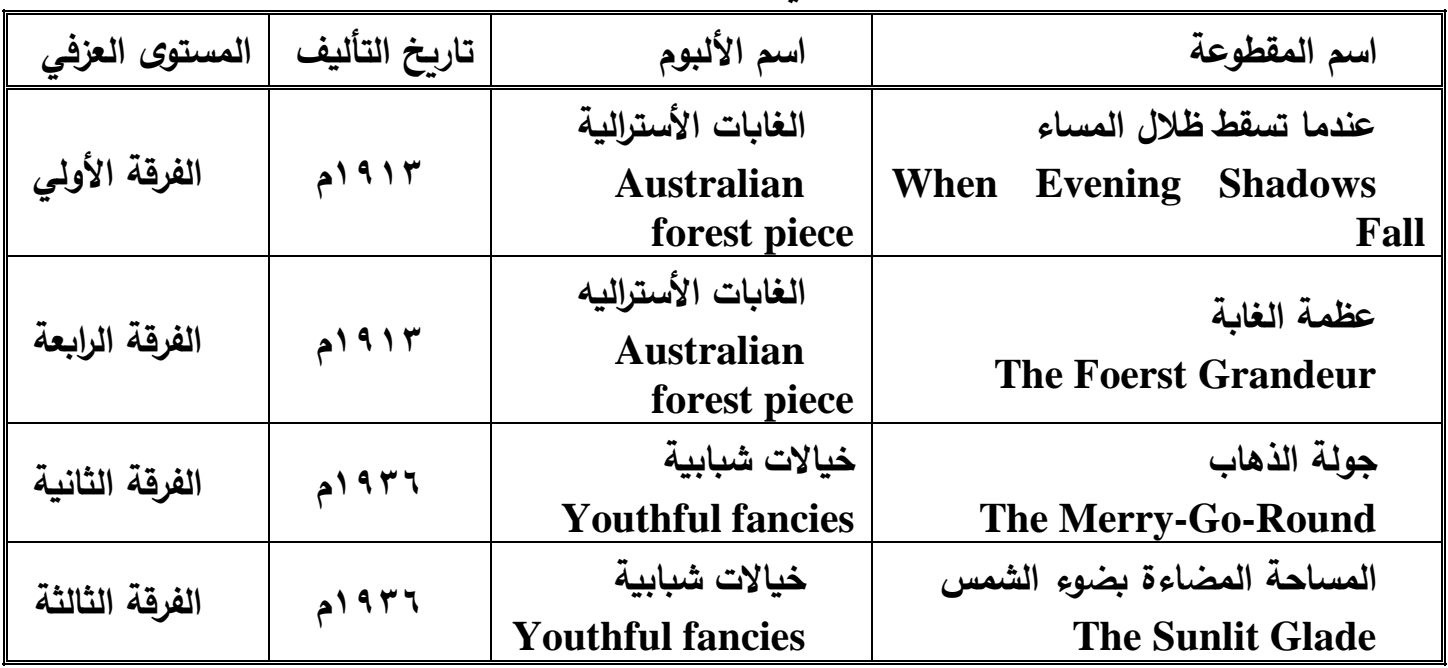

ج- حدود البحث:

- زمانية: بداية القرن العشرين.

- مكانية: أستراليا - كلية التربية الموسيقية جامعة حلوان .

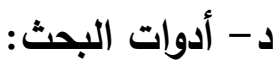

إستمارة استطلاع رأي الخبراء في تحديد المستوى العزفى لمقطوعات البيانو عند روي أجنيو.

$$
\text { مصطلحات البحث: }
$$

- Performance Style أسلوب الأداء

مصطلح يثير إلى السمات الميزه للعمل من حيث الفترة الزمنيه والمكان والمذهب وشخصية

المؤلف بإلاضافه الى تحليل العناصر الموسيقيه المكونه لها.'

- تقنيات الأداء Performance Techniques -

المهارات الضرورية الخاصة بالعزف على آلة البيانو التي تهذف إلى عزف متقن ومعبر في نفس الوقت.

${ }^{1}$ Randel, Don Michael: "The Harvard Concise Dictionary of Music and Musicians", Harvard College .Press, U.S.A, 2002, P.407

${ }^{1}$ Ibid:Randel, Don Michael, P.502

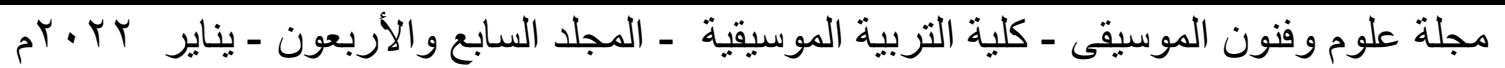


: علامات الأداء Performance Marks -

جميع المصطلحات أو الإختصارات أو العلامات المكتوبه فوق النغمات التى تثير إلى الى الثاء

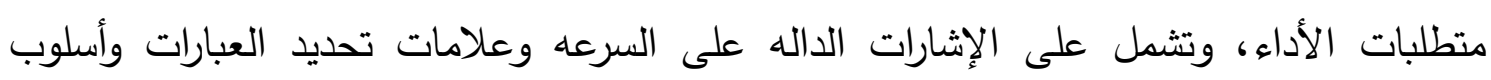
اللمس ونماذج إظهار طابع المؤلفه. الاراسات السابقة المرتبطة بموضوع البحث البع الراهن:

الدراسة الأولى: "موسيقى المكان: هوية آداء مهرجانات الموسيقى المجتمعية المعاصرة "الاسترالية)

Music of place: the Performance of Identity in Contemporary Australian Community Music Festival تهدف هذه الدراسة إلى إستعراض طرق آداء المهرجانات الموسيقية في استراليا، مثل مهرجان

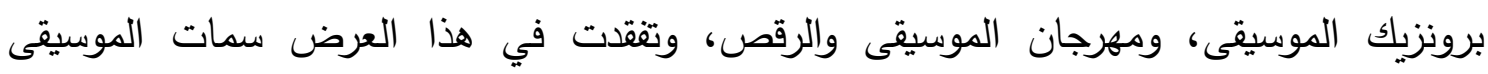

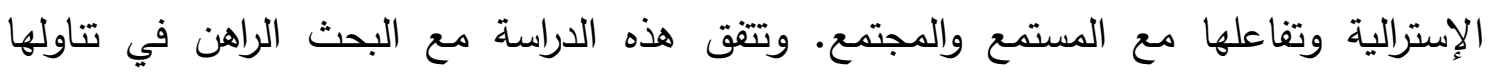

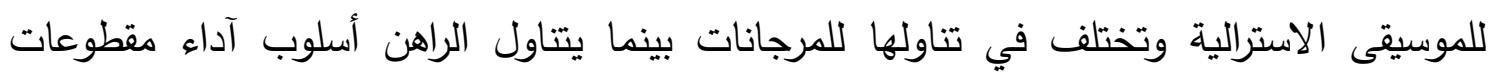
البيانوعند روي أجنيو.

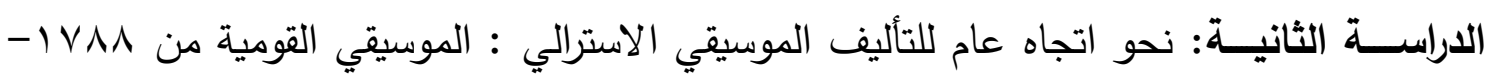

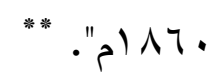

\section{Toward a General History of Australian Musical Composition:}

first national music 1788 - 1860.

تهدف هذه الدراسة إلى تتاول تاريخ التأليف الموسيقي في استراليا المبكرة وكيفية تطوره في

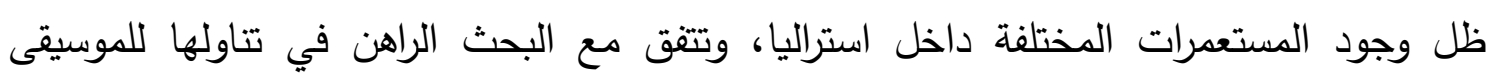

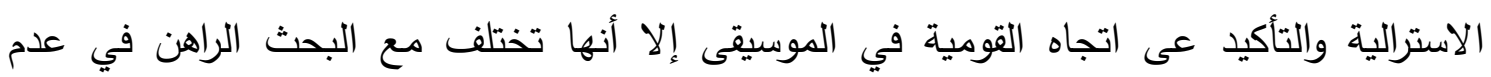

$$
\text { تطرقها لمؤلفات البيانو وأسلوب أدائها. }
$$

2 Agay, Denes:"Teaching Piano", Yorktown Press, Vol.1, New York, 1991, P.603

*Duffy, Michelle Elizabeth : Music of place: the Performance of Identity in Contemporary Australian Community Music Festival, Phd,Melbourne University,2001.

** Skinner, Graeme: "Toward a General History of Australian Musical Compositions", phd, University of Sydney,2011. first national music $1788-1860$

مجلة علوم وفنون الموسيقى - كلية التربية الموسيقية ـ المجلد السابع والأربعون - يناير بr بrم 


\section{- - الدراســة الثالثة}

(دراسة تحليلية لمؤلفات البيانو عند روي اجنيو ، مارجريت ساذرلالند و دولسي هولاند ... تثمل

السيرة الذاتية لهم)*

An analytical study of the piano works of Roy Agnew, Margaret

Sutherland, and Dulcie Holland, including biographical material تهدف هذه الدراسة إلي تحليل أعمال البيانو لثلاثة من المؤلفين الاستراليين وهم ، روي أجنيو

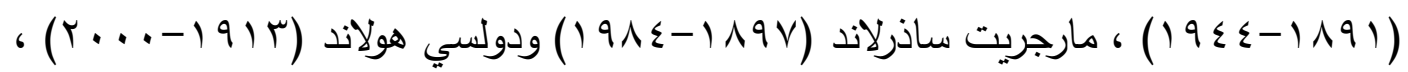

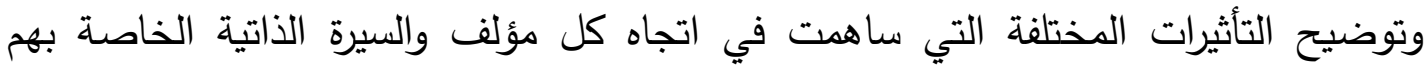
والمتطلبات الآدائية لمؤلفاتهم لآلة البيانو الخاصة بهم. وتتفق مع البحث الراهن في تتاولها لمؤلفات

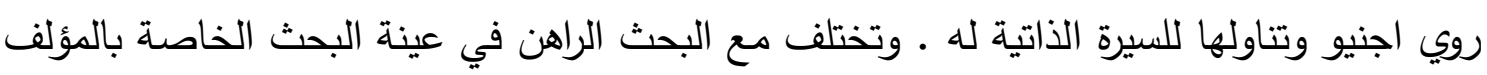

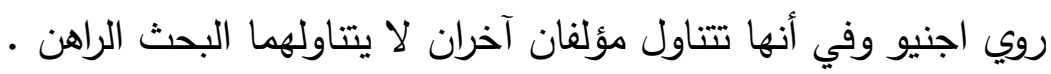

\section{- - الدراسـة الرابعة}

( مؤلفات روي اجنيو وهوبر بروستر باعتبارهم مؤلفين استراليين نظراء لمؤلفين الموسيقيى ** الاوروبية الحديثة)

The work of Roy Agnew and Hooper Brewster-Jones as an Australian counterpart to European modern music 1906-1949

تهدف الدراسة الي التعرف علي مؤلفات روي اجنيو وهوبر بروستر باعتبارهم مؤلفين

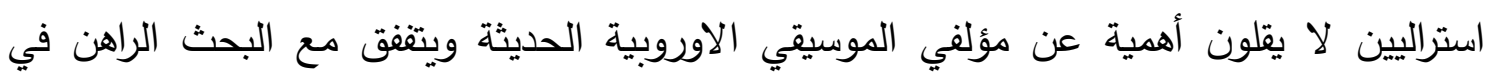

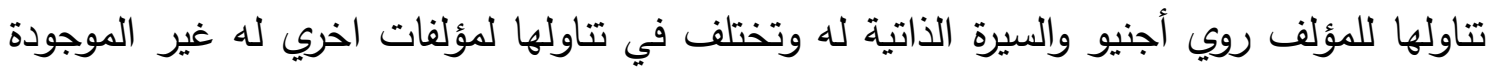
في عينة البحث مع تتاولها لمؤلف آخر لم تتناوله الباحثة في بحثها

* Crews, Rita : An analytical study of the piano works of Roy Agnew, Margaret Sutherland, and Dulcie Holland, including biographical material, Phd, University of New England 1997.

** Bowan, Kate : The work of Roy Agnew and Hooper Brewster-Jones as an Australian .counterpart to European modern music 1906-1949,phd, Australia National ,2007

مجلة علوم وفنون الموسيقى - كلية التربية الموسيقية - المجلد السابع والأربعون - يناير بr مبrم 


\section{- - الارراسة الخامسة \\ (موسيقي البيانو عند روي اجنيو)}

The piano music of Roy Agnew

تهدف هذه الدراسة الي التعرف علي سمات مؤلفات البيانو عند روي اجنيو ـ وتتقق مع البحث

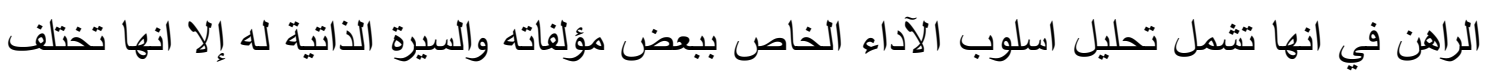

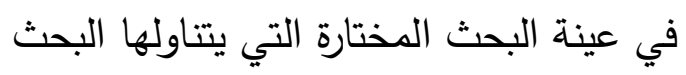

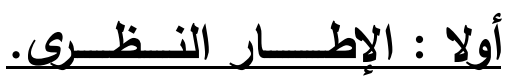

\section{- نبذة مختصرة عن سمات الموسيقي الأسترالية:}

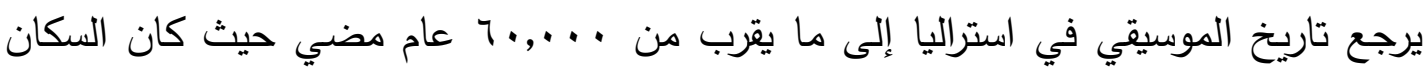
الأصليون وسكان جزر مضيق توريز يستخدمون الآلات الموسيقية القديمة في الاحتفال بالزواج وكانت آله الديدجيريدو" " Didgeridoo هي الآلة الأساسية في العزف في هذه الآت الفترة وتعد نوع من فئن الآلات الموسيقية الاسترالية التي استخدمها الكثير من الموسيقيين في الحفلات والتأليف في ذلانك

كانت استراليا عبارة عن مجموعة من المستعمرات البريطانية والتي لعبت دورا هاما في تأثر

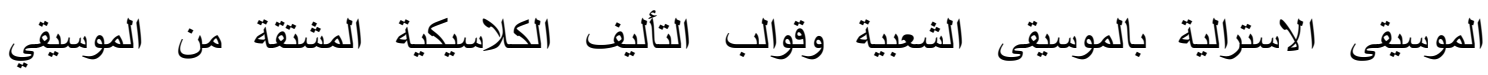
الأوروبية، كما تأثرت بالموسيقى الأمريكية حيث ظهر ذلك في موسيقي الدول الاسترالية

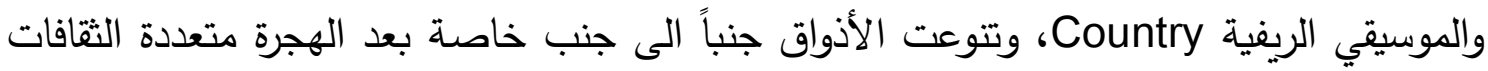
والجنسيات بعد الحرب العالمية الثانية الى استراليا ، فقد أدى الاندماج بين الاذبافيات السكان الأصليين

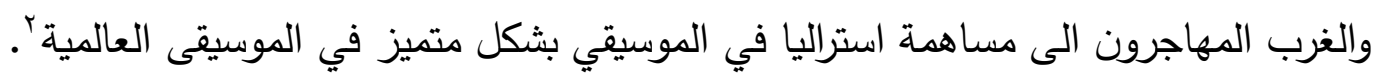

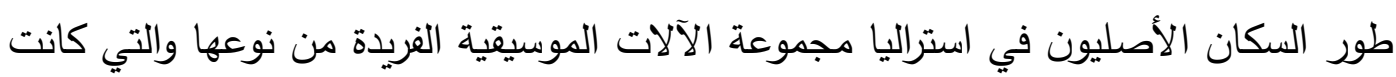
تستخدم في الحفلات وعلى راسهم آله الديدجيريدو، وقاموا بدمج اصواتها مع الآلات الموسيقية

*1981 Johnston, Faith: The piano music of Roy Agnew, MMus, University of Western Aust, 1981.

*** هي آله نفخ خشبية استخدمها السكان الإستر اليون الأصليون في موسيقاهم في استر اليا الثمالية ، وكانت أثبه بالترومبيت و لاتزال تستخدم علي نطاق واسع حتي الآن في استر اليا . لنئ.

1 http://www.Slideshare.net/violapond87/the-history-of-australain-music.P:1 .

${ }^{2}$ http://themusichistory.com/australia-music-history.html-P:1

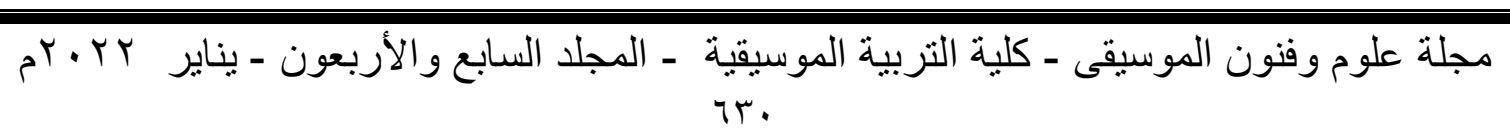


Gurrumul " *تقليدية، ومن اهم المؤلفين الذين استخدموا هذه الآلات جورمول يونوبينجو Yunupingu

تأثر التأليف لآلة البيانو في استراليا بالقوالب الكلاسيكية المعروفة في أوروبا نظرا لوجود المستوطنات الأوروبية فيها في القرن الثامن عشر ، فنجد الصوناتا والمقطوعات الحرة ولكن بروح

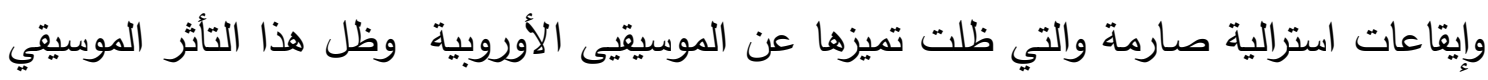
حتى نهاية القرن الثامن عش الي أن بدأ المؤلفون الإستراليون في الرحيل خارج البلاد لإيجاد فرصة الإدوبه

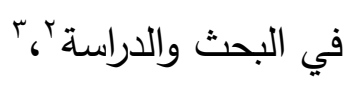

أدى ظهور الذهب في منتصف القرن التاسع عشر إلى ظهور ثقافة الطبقة الوسطي والطلب

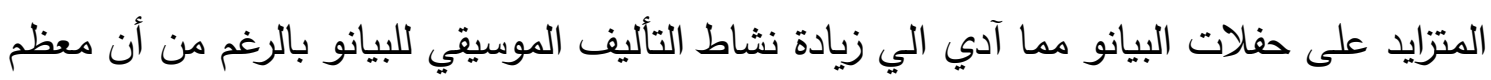

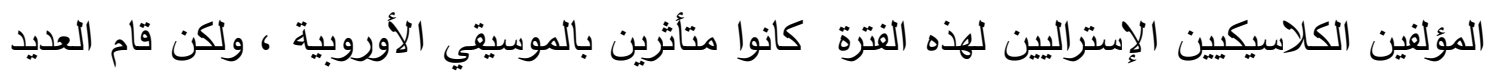

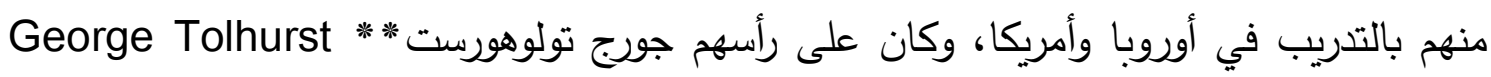

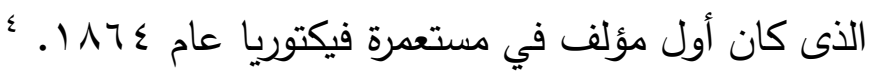

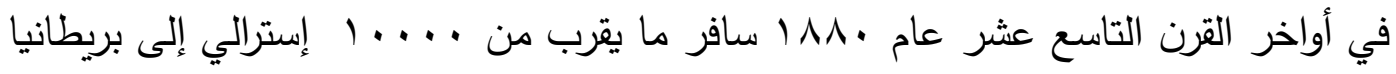

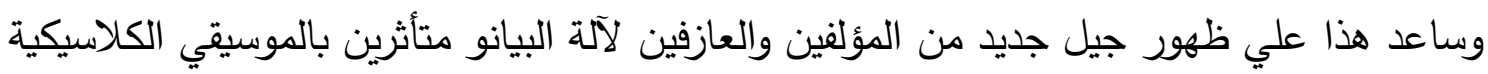

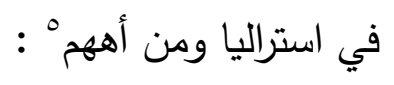

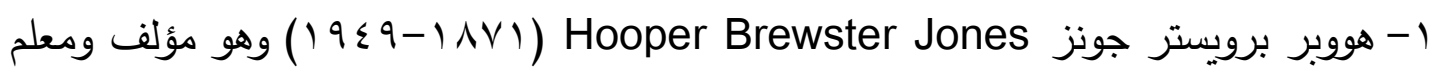
وناقد موسيقي ولد في استراليا ،حصل على منحة للدراسة وقضى ثلاث سنوات في الكلية

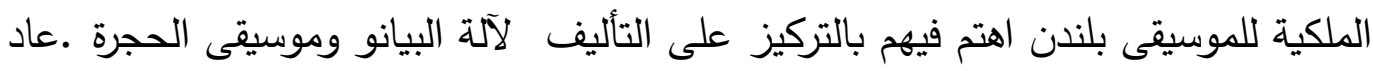

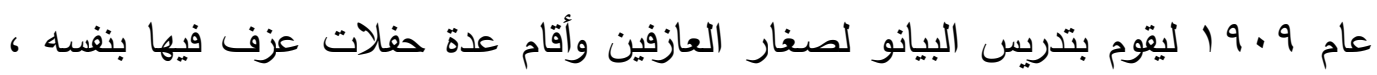

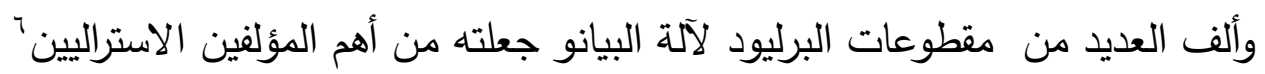

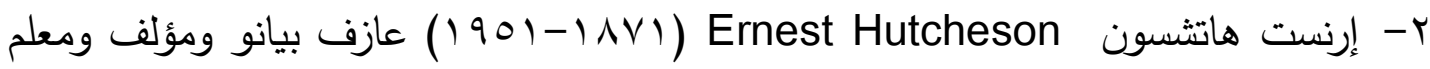
استرالي ولد في ملبورن، سافر الي ألمانيا في سن الرابعة عشر ثم قام بالتدريس في معهد

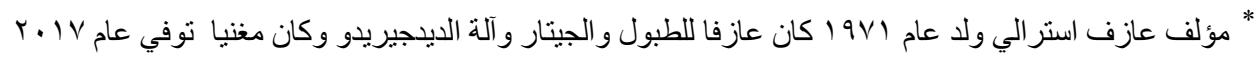

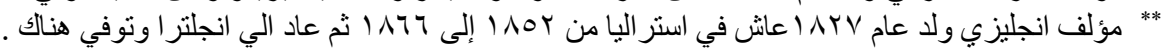
${ }^{1}$ australia.htm. http://www.australian-information-stories.com/music-of, p:

2 https://musicaustralia.org.au/discover/the-professional-music industry/music-in-australia.p:2 .

3 Latham, Alison: "The Oxford Companion to Music", Oxford Universisty press, 1938-P:72

${ }^{4}$ ibid : 4 Latham, Alison, p:75.

5 ibid : musicaustralia.org.au/discover/the-professional-music ,p:5 .

${ }^{6}$ Sitsky, Larry: Australian Piano Music of The 20 th Century, Library of Congress Cataloging-in-Publication Data,2005 .p : 55.

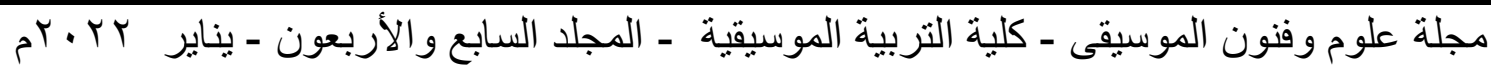


الموسيقي في برلين ولكنه استقر في نيويورك عام ع ا9 19 ، وعزف أولي حفلاته في

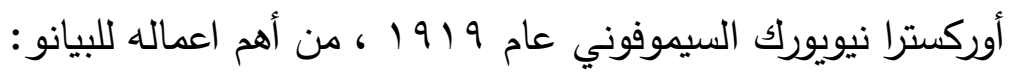
• • • بونشيرتو للبيانو المنفرد

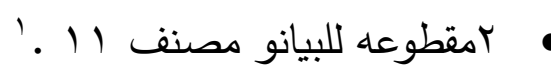

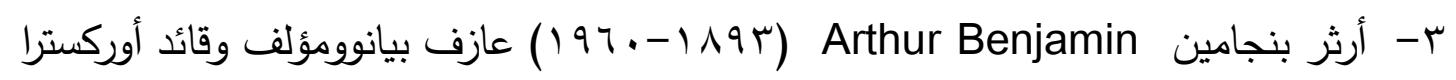

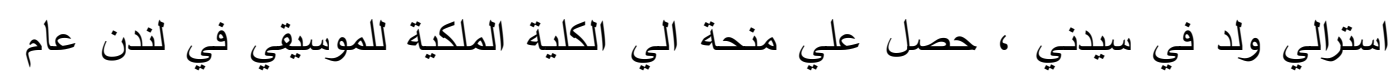

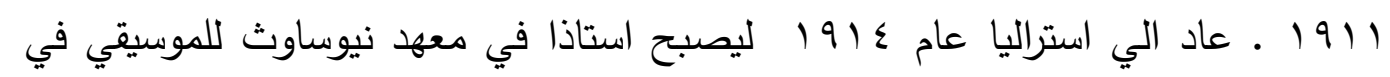

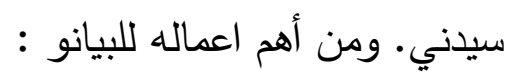
ثلاث مقطوعات للكمان والبيانو (919 (19-19 19 19 ) .

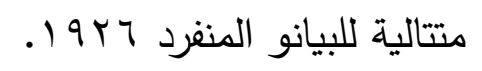

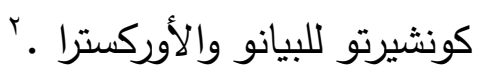

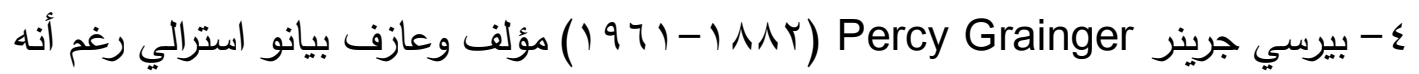

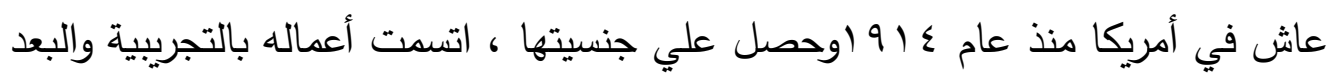

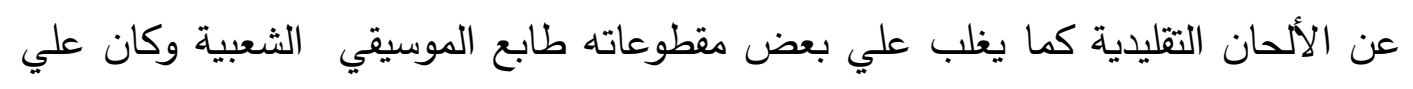

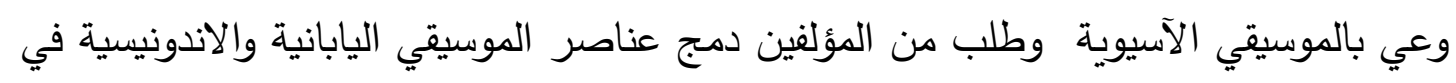

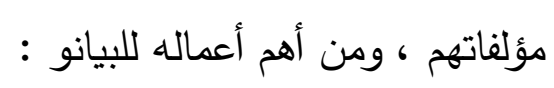

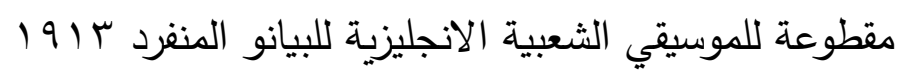

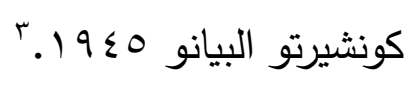

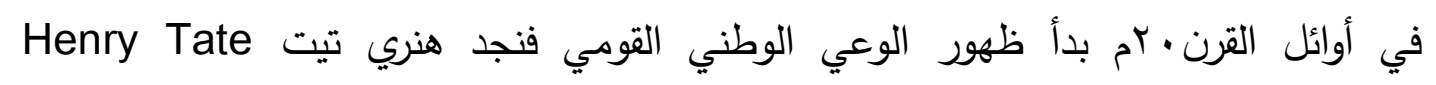

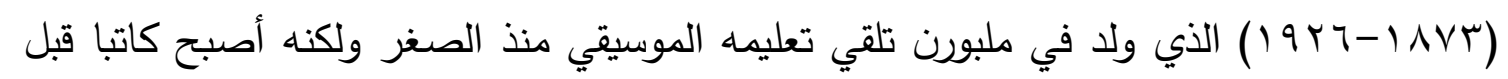

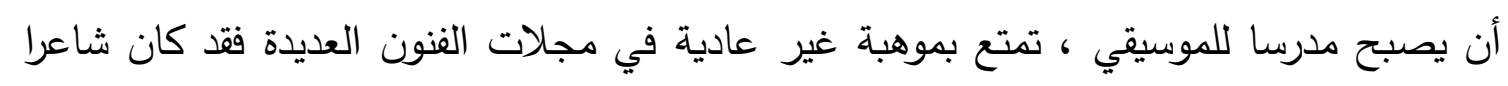

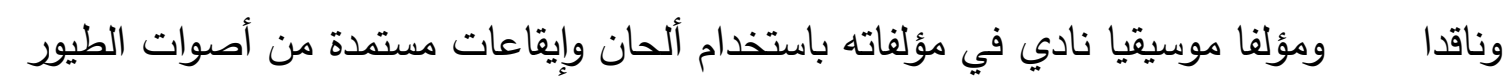

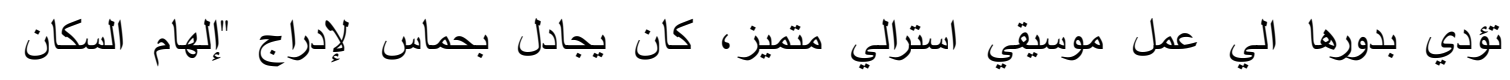

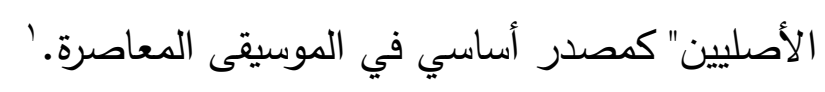

1 ibid : Sitsky, Larry: p : 86 .

2 ibid: Australian Piano Music of The 20 th Century.p:58. r

3 ibid: Australian Piano Music of The 20 th Century.p:58.

مجلة علوم وفنون الموسيقى - كلية التربية الموسيقية - المجلد السابع والأربعون - يناير r ·r بم 
آثناء الحرب العالمية الثانية إتجه المؤلفون أمثال روى أجنيو Roy Agnew وجون أنتل* وكلايف دوجلاس * John Antil

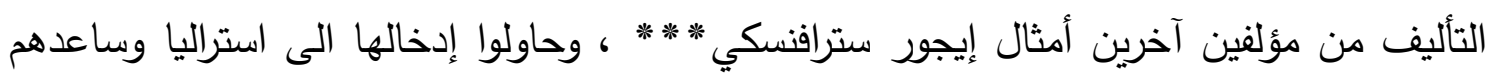

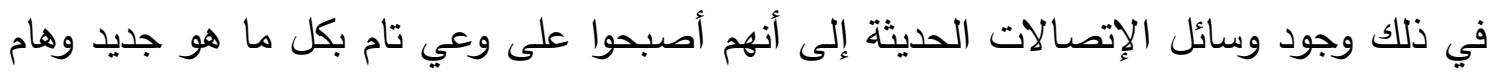

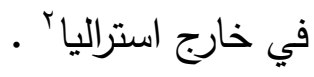

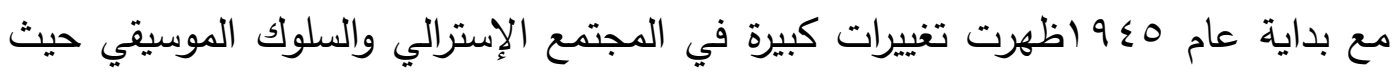

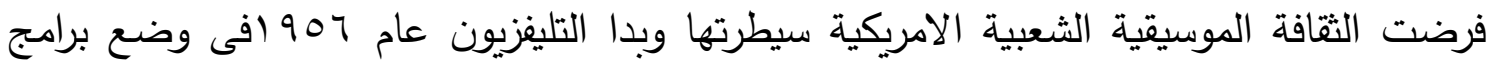
قوية كان لها أثر كبير في الثقافة الموسيقية الحديثة من خلال تأثرها بالموسيقي البريطانية

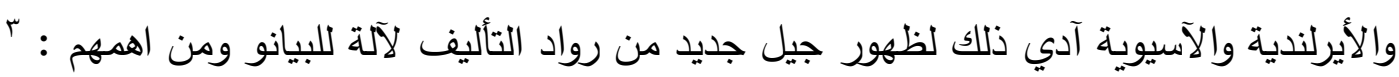

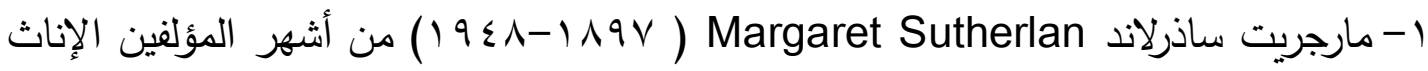
في استراليا ،كانت تميل الي الألحان الرومانسية برغم من انها تعتبر من أهم مؤلفي القرن

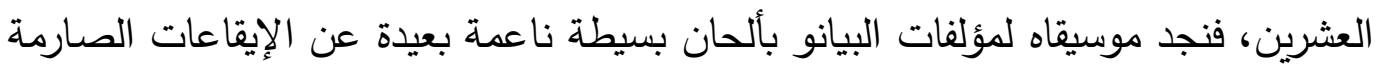

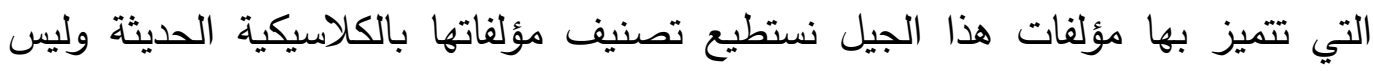
القرن العشرين ومن أهم اعمالها للبيانو : لهيل

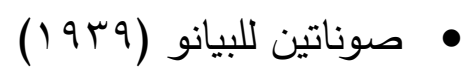

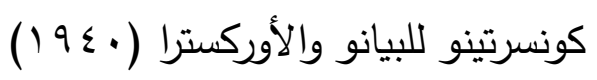

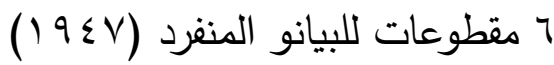
مقطوعة للبيانو المنفرد (197V)

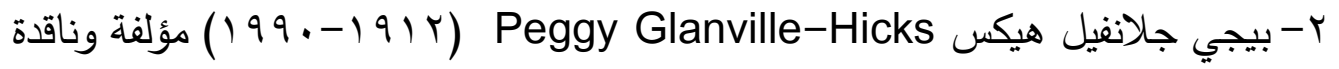

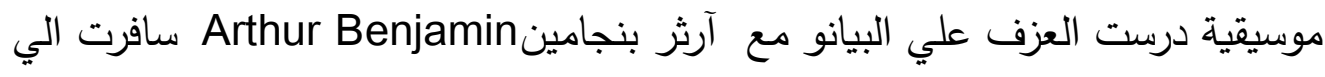

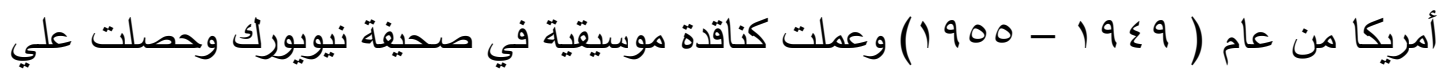

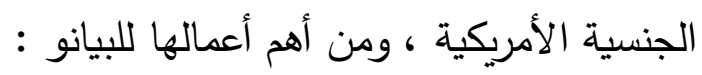

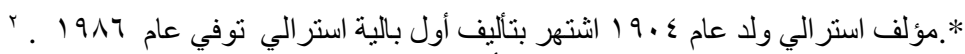

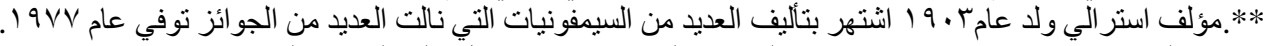

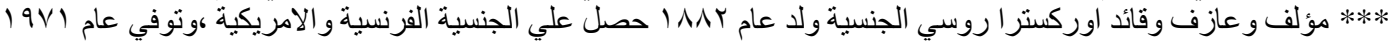
${ }^{1}$ Latham, Alison, p:81. 4 ibid:

2 ibid : Latham, Alison: P:73.

3 Sadie, Stanly: "The New Grove Dictionary of Music and Musicians"2th Edition,Vol, ,Oxford Universisty press, 2001-P:220.

4 ibid: Australian Piano Music of The 20 th Century.p:67

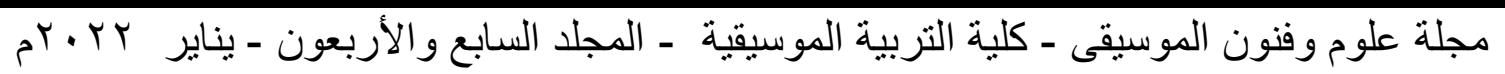




$$
\text { كونثيرتو للبيانو وأوركسترا الحجرة (1907) لبآلاتلات الإيقاعية (1901)' }
$$

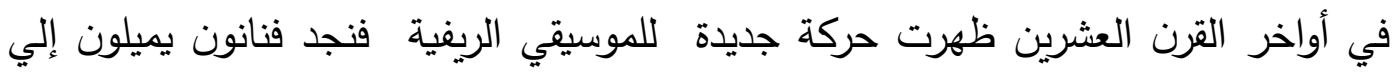
الحنين إلى الماضي في موسيقاهم وآخرون يبحثون عن أنماط مستوحاة من الموسيقي الريفية الأمريكية بمثابة رد على التغيير الاجتماعي والاهتمام العام والإعلامي الجديد بالهوية الوطنية.

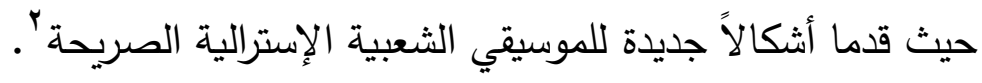

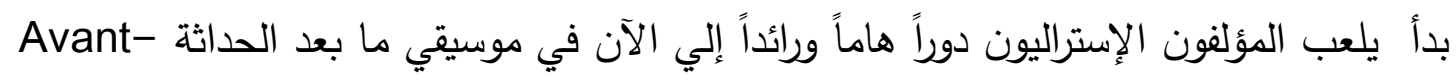

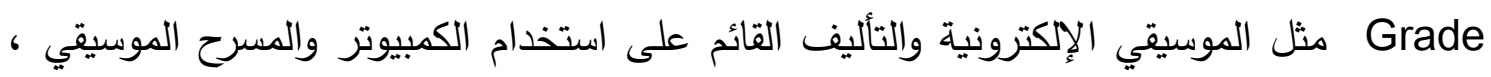

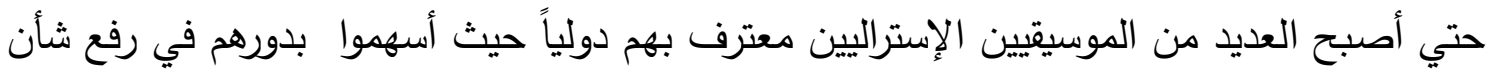
الموسيقي الإسترالية في جميع أنحاء العالم.

\section{- حياة روي أجنيو Roy Agnew ومؤلفاته الموسيقية}

هو روي إيوينج أجنيو Roy Ewing Agnew مؤلف وعازف بيانو ايطالي الجنسية ، ولد في مدينة سيدني يوم بr أغسطس عام (91/1، يعتبر أجنيو واحد من أهم مؤلفي القرن العشرين

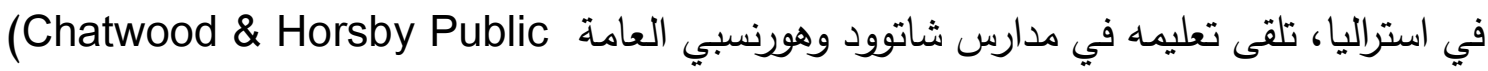
Schools)

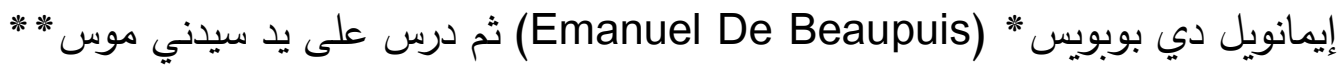

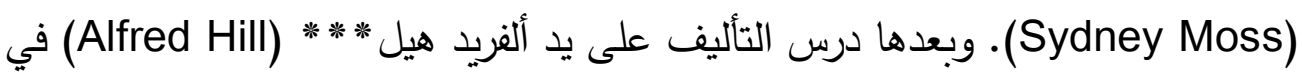

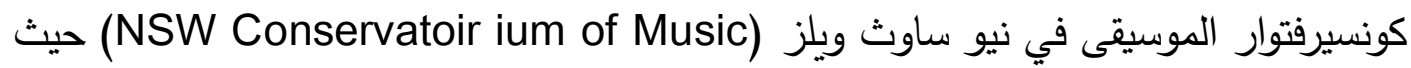

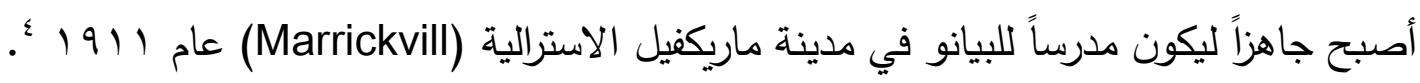

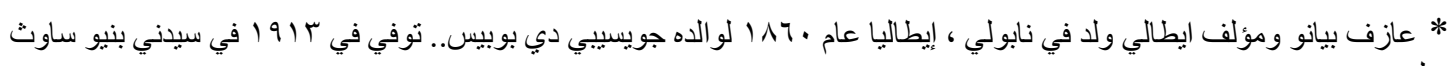

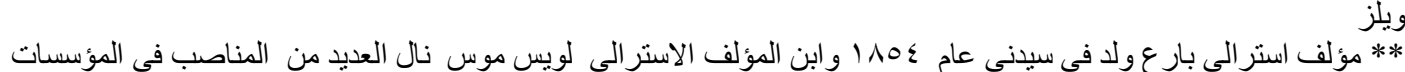

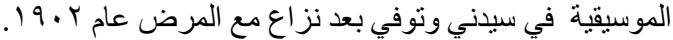

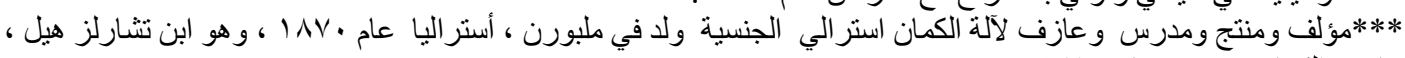
${ }^{1}$ ibib : Australian chamber music with piano, $\mathrm{p}: 95$

2 ibid : Latham, Alison: P:75.

3 ibib : Australian chamber music with piano , p :95

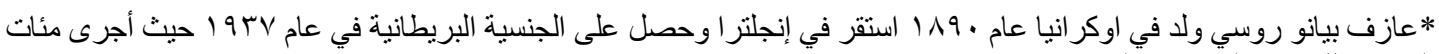

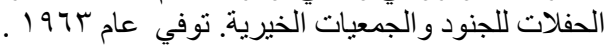

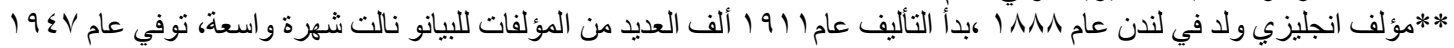

مجلة علوم وفنون الموسيقى - كلية التربية الموسيقية - المجلد السابع والأربعون - يناير بr بrم 
في عام 1911 وبعمله كمدرس للبيانو بدأ في تأليف أعماله الموسيقية التي كانت مُلفته للنظر، حيث تحرر فيها من قيود التونالية والعلاقات بين السلالم وهو ما كان غير متعارف عليه

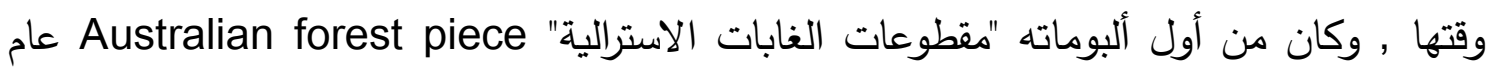
با 19 1. وقد كانت مؤلفاته غير معروفة حتى قام بينو موسيفيتش * (Benno Moiseiwitsch)

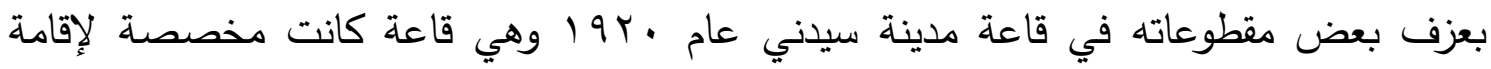

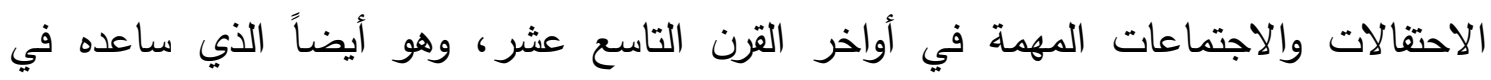

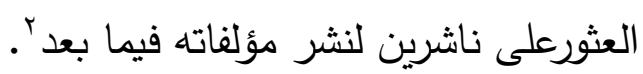

في عام rاب أسافر أجنيو الى لندن لدراسة التأليف الموسيقي والأوركسترا على يد جيرارد

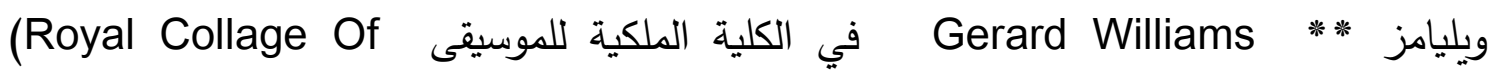
وأثناء وجوده هناك قدم عدة حفلات لأعمال بعض المؤلفين المعاصرين وقتها أمثال كلود

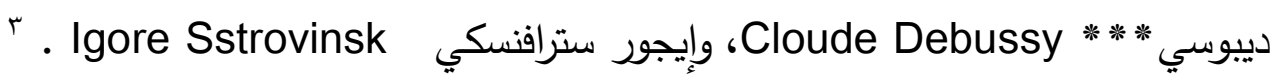
في عام 19r^ عاد الى مدينة سيدني وقدم عدة حفلات موسيقية لأعماله الخاصة ومنهم

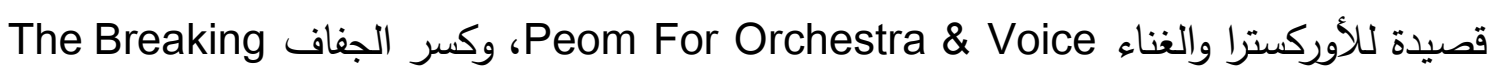
of drought

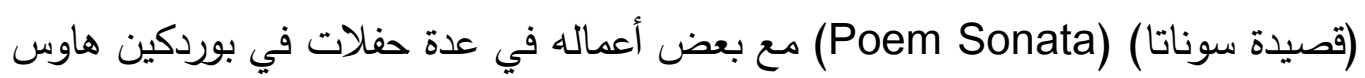
(BurdekinHouse) كاتدرائية سانت ماري . في عام اسب أسافر إلى بريطانيا وقدم حفلات لمؤلفاته الخاصة في ستوديو جورج وود هاوس (George Wood House Stodio) في لندن وقدم عروض لهيئة الاذاعة البريطانية

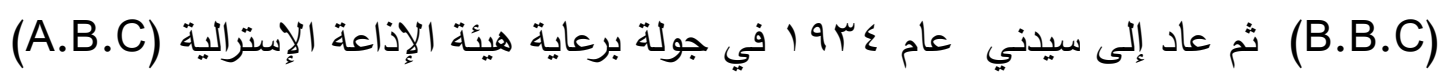

أعلن فيها عن بداية حفلاته الاذاعية لأعماله الخاصة وسلسلة دروس عن "فن البدال والتأليف" في مدينة ملبورن Melbourne

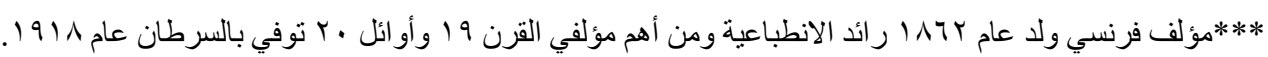

1 ibib : Australian chamber music with piano, p :95

2 Serle, Geoffrey and : Bede, Nairn :" Australian Dictionary of Biography”, vol:7, Melbourne

University press , 1891-1939. A-ch-P:574.

3 ibid:.australianmusiccentr.com-au/artist/agnew-roy-P:3

${ }^{4}$ ibid : Serle, Geoffrey and : Bede, Nairn :-P:575.

${ }^{1}$ https://britishmusiccollection.org.uk/composer/roy-agnew, p:2

مجلة علوم وفنون الموسيقى - كلية التربية الموسيقية ـ المجلد السابع والأربعون - يناير بr بrم 
في عام 1941 عمل أجنيو في (A.B.C) كمقدماً لبرنامج أسبوعي حول الموسيقى المعاصرة بعنوان "جلسة المؤلفين المعاصرين" قام فيه بنشر أعمال وموسيقى كلود ديبوسي وإيجور لهاني

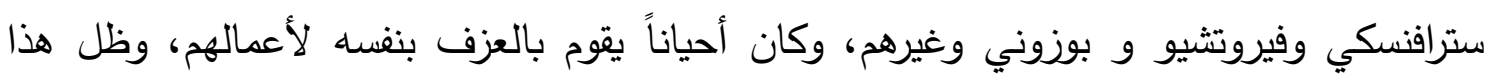

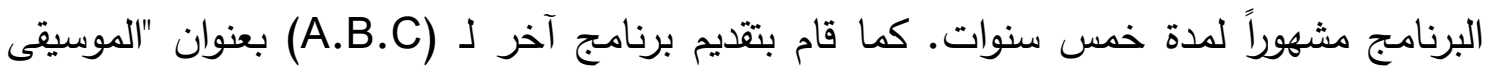

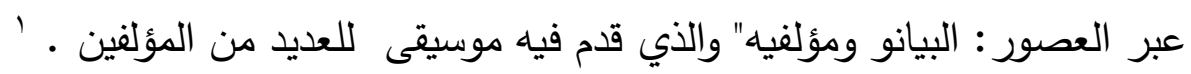

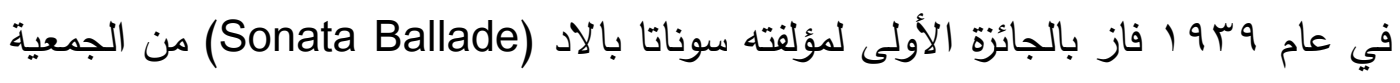

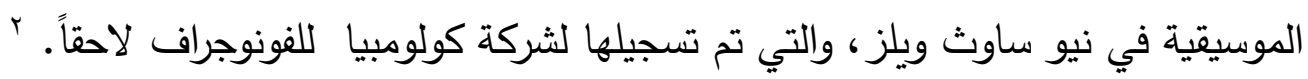

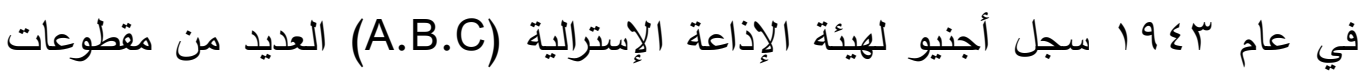

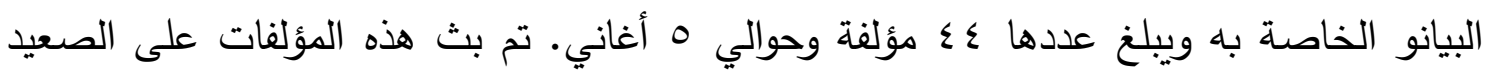

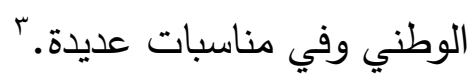

بصرف النظر عن مسيرة أجنيو المهنية كعازف ومعلم بيانو متميز ، ومُعلماً لفن التأليف

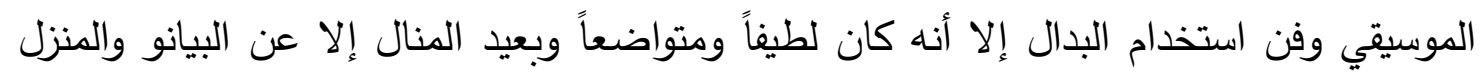

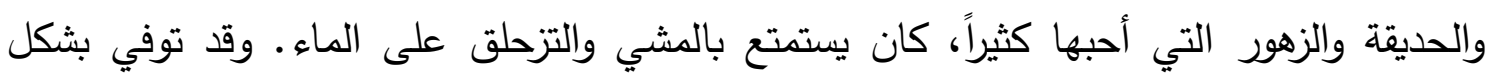

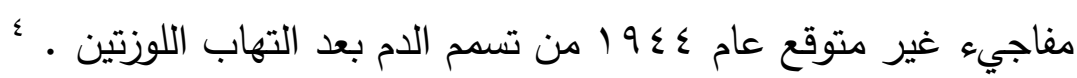

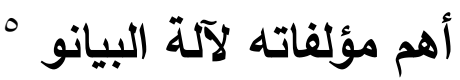

Symphonic Poeme

Sonata Legend(Capricorn

pieces Australian Forest

Dance Of The Wild Men

Deirdre's Lament

Poem Tragiqe

Fantasie Sonata

Rhapsody

Rabbit Hill

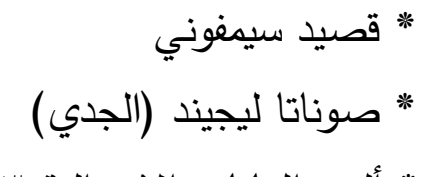

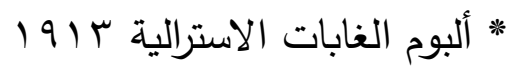

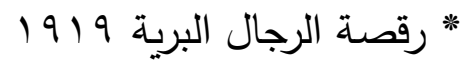

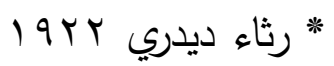

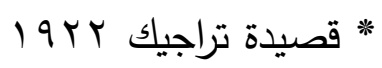

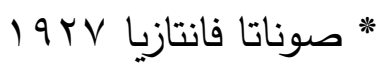

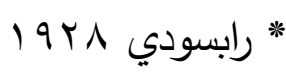

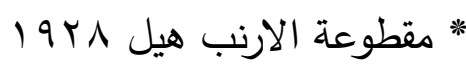

2 ibid: Serle, Geoffrey and : Bede, Nairn, p : 577

3 ibid : Serle, Geoffrey and : Bede, Nairn, p : 580.

4 ibid:.australianmusiccentr.com-au/artist/agnew-roy-P:3

5 ibid : britishmusiccollection.org, p:3

6 ibid : Serle, Geoffrey and : Bede, Nairn , p: 599.

مجلة علوم وفنون الموسيقى - كلية التربية الموسيقية - المجلد السابع والأربعون - يناير بr ·r 
Sonatas

Youthful Fancies

Symphonic Poeme

Holiday Suite

Sonata Ballad
19 19 صونات * (20)

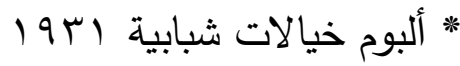

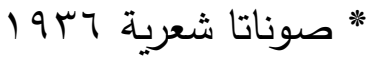

|

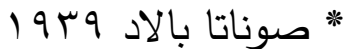

ثانيا: الإطـــار التطبـقي

يتضمن دراسة تحليلية عزفية لبعض مقطوعات آلة البيانو في استراليا عند روي أجنيو لتحديد التقنيات العزفية وتوضيح متطلبات آدائها وقد اتخذت الباحثة الإجراءات الآتية :

•دراسة مسحية لألبومين من تأليف روي أجنيو قامت الباحثة باختيار عينة البحث منهم وهما:

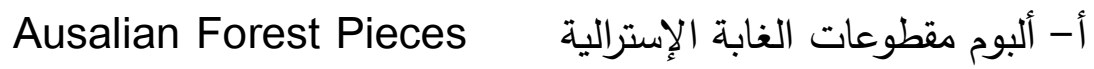

Fancies Youthful

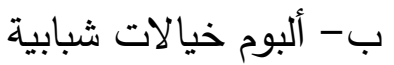

وسوف تتناولهم الباحثة من حيث (السلم - السرعة - الميزان - الطول البنائي - النسيج -

الصيغة) كما هو مبين في الجدول رقم (r) و (r)

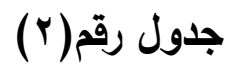

دراسة مسحية لمقطوعات البيانو في ألبوم مقطوعات الغابة الاسترالية

Ausalian Forest Pieces

\begin{tabular}{|c|c|c|c|c|c|c|}
\hline الصيغة & النسيج & البنائي & الميزان & السرعة & السلم & المؤلفة \\
\hline ثلاثية & هوموفوني & $\sum 4$ & $\begin{array}{l}2 \\
4\end{array}$ & $\begin{array}{c}\text { Play Fully } \\
\text { طفولية بروح الدعابة }\end{array}$ & صول/الصغير & $\begin{array}{c}\text { رقصة القزم } \\
\text { Gnome } \\
\text { Dance }\end{array}$ \\
\hline ثلاثية & هوموفوني & or & $\begin{array}{l}2 \\
4\end{array}$ & $\begin{array}{l}\text { Very tenderly } \\
\text { بحنان ورقة شديدة }\end{array}$ & سي/الكبير & $\begin{array}{c}\text { ظدلدما تسقط المساء } \\
\text { When } \\
\text { evening } \\
\text { Shadows } \\
\text { Fall }\end{array}$ \\
\hline
\end{tabular}

مجلة علوم وفنون الموسيقى - كلية التربية الموسيقية ـ المجلد السابع والأربعون - يناير بr •YTم 


\begin{tabular}{|c|c|c|c|c|c|c|}
\hline ثلاثية & هوموفوني & 07 & $\begin{array}{l}6 \\
8\end{array}$ & $\begin{array}{l}\text { With Humour } \\
\text { بروح فكاهية }\end{array}$ & سي/ الصغير & $\begin{array}{c}\text { حوريات الغابة } \\
\text { تلعبن } \\
\text { Forest } \\
\text { nymphs at } \\
\text { play }\end{array}$ \\
\hline ثلاثية & هوموفوني & M & $\begin{array}{l}4 \\
4\end{array}$ & $\begin{array}{l}\text { Somewhat } \\
\text { Vague \& } \\
\text { mysterious } \\
\text { وغير واضح غامضح } \\
\text { غشكل }\end{array}$ & لا / الصغير & $\begin{array}{l}\text { الغابة ليلة في } \\
\text { Night } \\
\text { in The } \\
\text { Forest }\end{array}$ \\
\hline ثلاثية & هوموفوني & rᄉ & 4 & $\begin{array}{c}\text { Quality } \\
\text { moving } \\
\text { Throughout } \\
\text { الإلتزام بطابع عام وعدم } \\
\text { بحرية }\end{array}$ & لا/الصغير & $\begin{array}{c}\text { هواديء تياء } \\
\text { By A } \\
\text { Quiet } \\
\text { Streem } \\
\end{array}$ \\
\hline ثلاثية & هوموفوني & $r r$ & $\begin{array}{l}4 \\
4\end{array}$ & $\begin{array}{l}\text { With Dignity } \\
\text { and breadth } \\
\text { بفخر وكرامة }\end{array}$ & صول/الصغير & $\begin{array}{l}\text { الغابة عظمة } \\
\text { Thest } \\
\text { Forest } \\
\text { grandeur }\end{array}$ \\
\hline
\end{tabular}

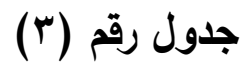

Fancies Youthful دراسة مسحية لمقطوعات البيانو في ألبوم خيالات شبابية

\begin{tabular}{|c|c|c|c|c|c|c|}
\hline الصيغة & النسيج & الطول البنائي & الميزان & السرعة & السلم & عنوان المؤلفة \\
\hline ثلاثية & هوموفوني & or & $\begin{array}{l}4 \\
4\end{array}$ & $\begin{array}{l}\text { Brightly } \\
\text { and gaily with } \\
\text { humour } \\
\text { ودععابة ووضوح }\end{array}$ & فا/ الكبير & $\begin{array}{l}\text { مرح الذهب } \\
\text { The Merry } \\
\text { Gold Round }\end{array}$ \\
\hline ثلاثية & هوموفوني & rq & $\begin{array}{l}4 \\
4\end{array}$ & $\begin{array}{l}\text { Very fast } \\
\text { and Light } \\
\text { سريع بخفة }\end{array}$ & ري/الصغر & $\begin{array}{c}\text { نهر الغرغرة } \\
\text { The } \\
\text { Gurgling } \\
\text { Brook }\end{array}$ \\
\hline ثلاثية & هوموفوني & 00 & $\begin{array}{l}3 \\
4\end{array}$ & $\begin{array}{c}\text { Very } \\
\text { delicately,and } \\
\text { good moving } \\
\text { pace } \\
\text { throughout } \\
\text { بنعومة جدا }\end{array}$ & فا/ الكبير & $\begin{array}{l}\text { المضاءة بضوء الثمسحة } \\
\text { الثمس } \\
\text { The Sun } \\
\text { Light Glad }\end{array}$ \\
\hline
\end{tabular}

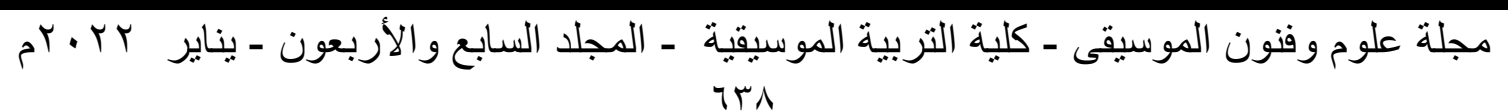




\begin{tabular}{|c|c|c|c|c|c|c|}
\hline & & & & وسرعة معتدلة & & \\
\hline ثلاثية & هوموفوني & $\leqslant V$ & $\begin{array}{l}6 \\
8\end{array}$ & $\begin{array}{l}\text { With great } \\
\text { delicately,and } \\
\text { tenderness } \\
\text { برقة وحنان } \\
\text { بديدين }\end{array}$ & لا / الكبير & $\begin{array}{r}\text { طفل نائم } \text { Sleeping } \\
\text { Child }\end{array}$ \\
\hline
\end{tabular}

قامت الباحثة بتصميم استمارة استطلاع رأي الأساتذة المتخصصين في تصنيف المستوى التعليمي للمقطوعات التي يشتمل عليها الألبومين وبناءاً على رأي الخبراء ( • أساتذة في مادة البيانو في الكلية ) تم تحديد المستوى التعليمي للمقطوعات حسب آرائهم في الجدولين التاليين

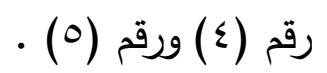

\section{جدول رقم (؛)}

تصنيف المستوى التعليمي لمقطوعات البيانو عند روي أجنيو في ألبوم مقطوعات الغابة Ausalian Forest Pieces الاسترالية

\begin{tabular}{|c|c|c|}
\hline آراء الخبراء & المستوى العزفي المقترح & إسم المقطوعة \\
\hline ------------ & تتاسب الفرقة التحضيرية & \multirow{5}{*}{$\begin{array}{c}\text { Gnome Dance } \\
\text { رقصة جنوم }\end{array}$} \\
\hline$\% \varepsilon$ & تناسب الفرقة الأولى & \\
\hline$\%$ & تناسب الفرقة الثانية & \\
\hline ------------ & تناسب الفرقة الثالثة & \\
\hline -------------- & تتاسب الفرقة الرابعة & \\
\hline ----------- & تناسب الفرقة التحضيرية & \multirow{5}{*}{$\begin{array}{c}\text { When evening Shadows Fall } \\
\text { عندما تسقط ظلال المساء }\end{array}$} \\
\hline$\% 9$ & تناسب الفرقة الأولى & \\
\hline$\%$. & تناسب الفرقة الثانية & \\
\hline ---------- & تناسب الفرقة الثالثة & \\
\hline ----------- & تتاسب الفرقة الرابعة & \\
\hline --------- & تتاسب الفرقة التحضيرية & \multirow{5}{*}{$\begin{array}{l}\text { Forest nymphs at play } \\
\text { حوريات الغابة تلعبن }\end{array}$} \\
\hline ----------- & تناسب الفرقة الأولى & \\
\hline$\%$ & تناسب الفرقة الثانية & \\
\hline$\% 7$. & تناسب الفرقة الثالثة & \\
\hline$\% r$ & تتاسب الفرقة الرابعة & \\
\hline ------- & تتاسب الفرقة التحضيرية & \multirow{5}{*}{$\begin{array}{l}\text { Night in The Forest } \\
\qquad \begin{array}{l}\text { ليلة في الغابة }\end{array}\end{array}$} \\
\hline ------- & تناسب الفرقة الأولى & \\
\hline$\%$. & تناسب الفرقة الثانية & \\
\hline$\%$ & تناسب الفرقة الثالثة & \\
\hline$\%$ & تتاسب الفرقة الرابعة & \\
\hline -------- & تتاسب الفرقة التحضيرية & By A Quiet Streem \\
\hline
\end{tabular}

مجلة علوم وفنون الموسيقى - كلية التربية الموسيقية - المجلد السابع والأربعون - يناير بr ·rم 


\begin{tabular}{|c|c|c|}
\hline آراء الخبراء & المستوى العزفي المقترح & إسم المقطوعة \\
\hline ---------- & تتاسب الفرقة الأولى & \multirow{4}{*}{ بجوار تيار هاديء } \\
\hline$\% 1$ & تناسب الفرقة الثانية & \\
\hline$\% \vee \cdot$ & تناسب الفرقة الثالثة & \\
\hline$\%$. & تناسب الفرقة الرابعة & \\
\hline --------- & تتاسب الفرقة التحضيرية & \multirow{5}{*}{$\begin{array}{c}\text { The Forest grandeur } \\
\qquad \text { عظمة الغابة }^{\text {The }}\end{array}$} \\
\hline --------- & تناسب الفرقة الأولى & \\
\hline ---------- & تناسب الفرقة الثانية & \\
\hline$\%$. & تناسب الفرقة الثالثة & \\
\hline$\%$. & تتاسب الفرقة الرابعة & \\
\hline
\end{tabular}

جدول رقم (0)

تصنيف المستوى التعليمي لمقطوعات البيانو عند روي أجنيو في البوم مقطوعات خيالات

Fancies Youthful شبابية

\begin{tabular}{|c|c|c|}
\hline آراء الخبراء & المستوى العزفي المقترح & إسم المقطوعة \\
\hline ------------ & تتاسب الفرقة التحضيرية & \multirow{5}{*}{ 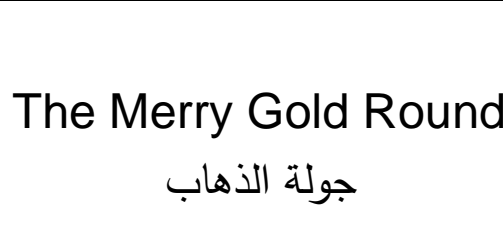 } \\
\hline$\% \varepsilon$ & تتاسب الفرقة الأولى & \\
\hline$\%$ & تناسب الفرقة الثانية & \\
\hline ------------- & تناسب الفرقة الثالثة & \\
\hline ------------- & تتاسب الفرقة الرابعة & \\
\hline$\%$ & تناسب الفرقة التحضيرية & \multirow{5}{*}{$\begin{array}{l}\text { The Gurgling Brook } \\
\text { نهر الغرغرة }\end{array}$} \\
\hline$\%$. & تناسب الفرقة الأولى & \\
\hline$\% \varepsilon$. & تناسب الفرقة الثانية & \\
\hline$\%$ & تناسب الفرقة الثالثة & \\
\hline --------- & تتاسب الفرقة الرابعة & \\
\hline ------- & تتاسب الفرقة التحضيرية & \multirow{5}{*}{$\begin{array}{c}\text { The Sunlit Glade } \\
\text { المساحة المضاءة بضوء الثمس } 1 \text { الثماءو }\end{array}$} \\
\hline$\%$ & تناسب الفرقة الأولى & \\
\hline$\% \varepsilon$. & تناسب الفرقة الثانية & \\
\hline$\%$ & تناسب الفرقة الثالثة & \\
\hline $\begin{array}{l}------- \\
\end{array}$ & تناسب الفرقة الرابعة & \\
\hline - ------ & تتاسب الفرقة التحضيرية & \multirow{5}{*}{$\begin{array}{l}\text { Sleeping Child } \\
\text { طفل نائم }\end{array}$} \\
\hline ------- & تناسب الفرقة الأولى & \\
\hline -------- & تناسب الفرقة الثانية & \\
\hline$\% \vee$ & تناسب الفرقة الثالثة & \\
\hline$\%$. & تتاسب الفرقة الرابعة & \\
\hline
\end{tabular}

أسباب اختيار عينة البحث

قامت الباحثة باختيار مقطوعتين من كل ألبوم وقد راعت في اختيار العينة ما يلي:

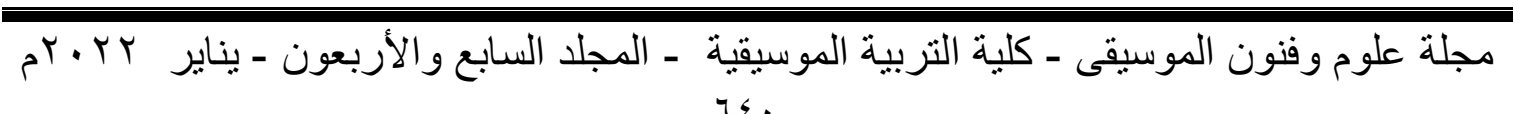


- أن تكون المقطوعات متتوعة التقنيات الآدائية والمستوى العزفي -

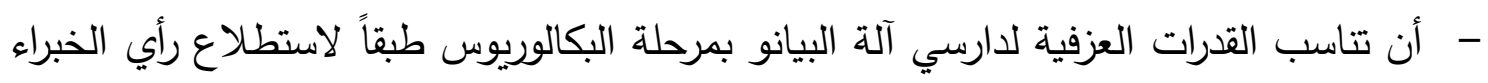

$$
\text { وتتضمن العينة أربعة مقطوعات هي: }
$$

ا-مقطوعة عندما تسقط ظلال المساء

Ausalian Forest Pieces من ألبوم الغابات الإسترالية

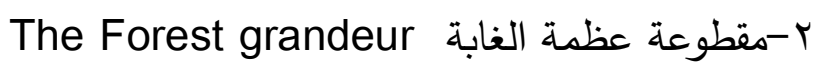

Ausalian Forest Pieces من ألبوم الغابات الإسترالية

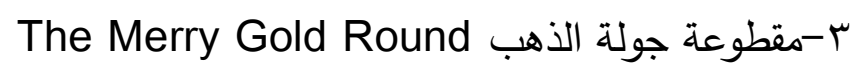

Fancies Youthful من ألبوم خيالات شبابية جوعة

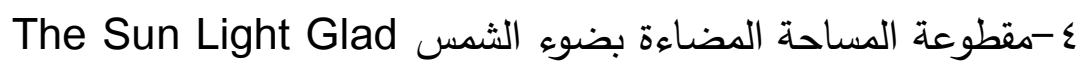

Fancies Youthful من ألبوم خيالات شبابية

وسوف تتناول الباحثة عينة البحث بالدراسة التحليلية والعزفية على النحو التالي:

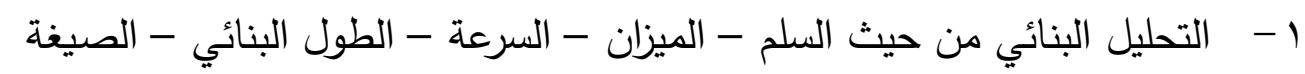

r- التحليل العزفي : وقد استعانت الباحثة باستمارة التحليل العزفي المتعارف عليعا

وتتضمن

( اللحن والدصاحبة - الايقاع - مصطلحات التعبير والسرعة - التظليل الديناميكي - التيكات التيات التيات

الدواس - الحليات - التتنيات العزفية و منطلبات أدائها)

\author{
المقطوعة الاولى دمالى \\ عندما تسقط الظلال المسائية \\ When Evening Shadows Fall \\ ( رقم r فى ألبوم مقطوعات الغابات الإسترالية )

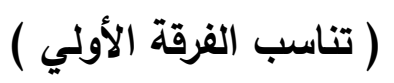

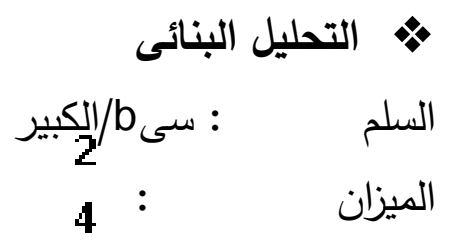

مجلة علوم وفنون الموسيقى - كلية التربية الموسيقية - المجلد السابع والأربعون - يناير بr ·rم 


$$
\begin{array}{r}
\text { الطول البنائي } \\
\text { البرعة : }
\end{array}
$$$$
\text { الفكرة الاولى A : من أناكروز م (1): م(اب)' قفلة تامة فى سلم سى إ/الكبير }
$$

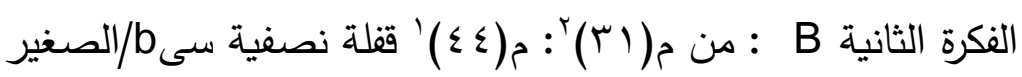

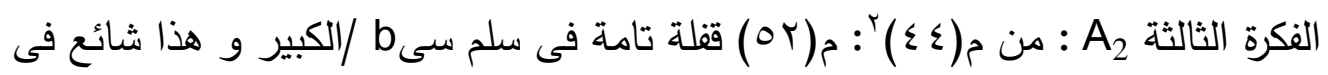

الموسيقى الثعبية

$$
\text { التحليل العزفى }
$$

وفية تتناول الباحثة مايلى :

* اللحن والمصاحبة و

$$
\text { - الفكرةالأولي A : من أناكروز م (1) : م (اسب)' }
$$

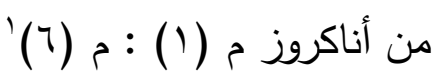

جاء اللحن فى اليد اليمنى فى صوت السوبرانو على شكل نغمات سليمة ومسافات لحينة لمسافة الثالثة والرابعة يصاحبة لحن كروماتى فى الصوت الداخلى على شكل نغمات مفردة على الى ايقاع ( • ) ، بينما جاءت المصاحبة فى اليد اليسرى على شكل نغمات (هارمونية ) على مسافة

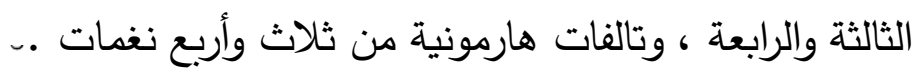

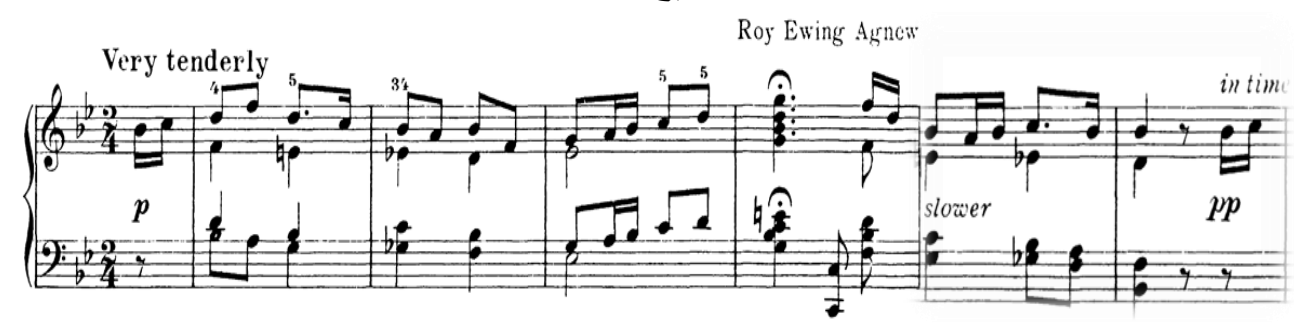

شكل رقم (1) يوضح من مازورة (1-4)

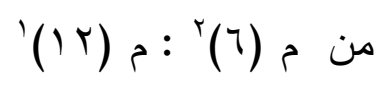

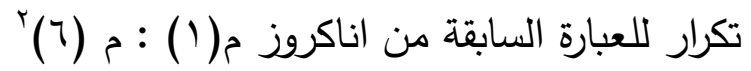

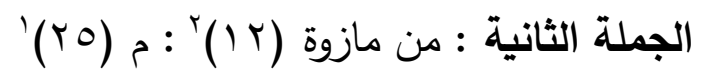

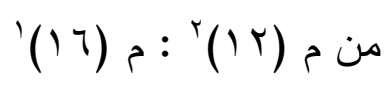

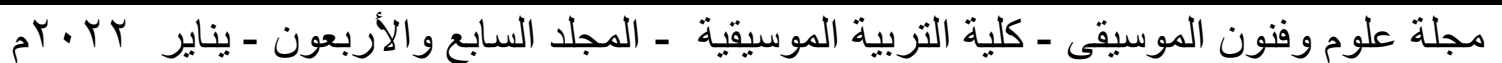


ظهر اللحن الاساسى فى اليد اليمنى باستخدام ايقاعات الجملة السابقة مع ظهور اللحن

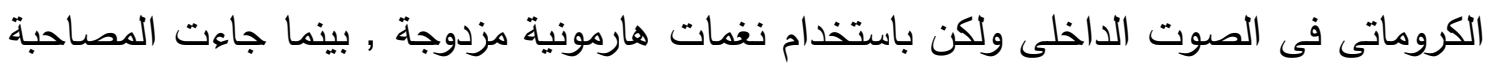

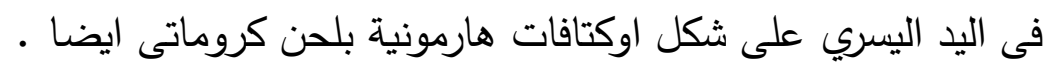

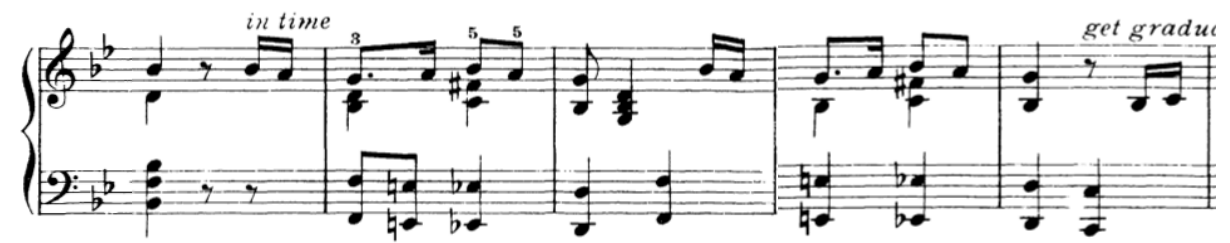

شكل رقم(ץ) يوضح من مازورة (r I- 17 )

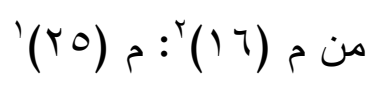

جاء اللحن فى اليد اليمنى عبارة عن تالفات هارمونية ثلاثية ورباعية بينما جاءت المصاحبة على شكل اوكتافات هارمونية بلحن كروماتى كما فى العبارة السابقة مع استخدام التآلفات الهارمونية من أربع نغمات إلي نهاية القفلة .

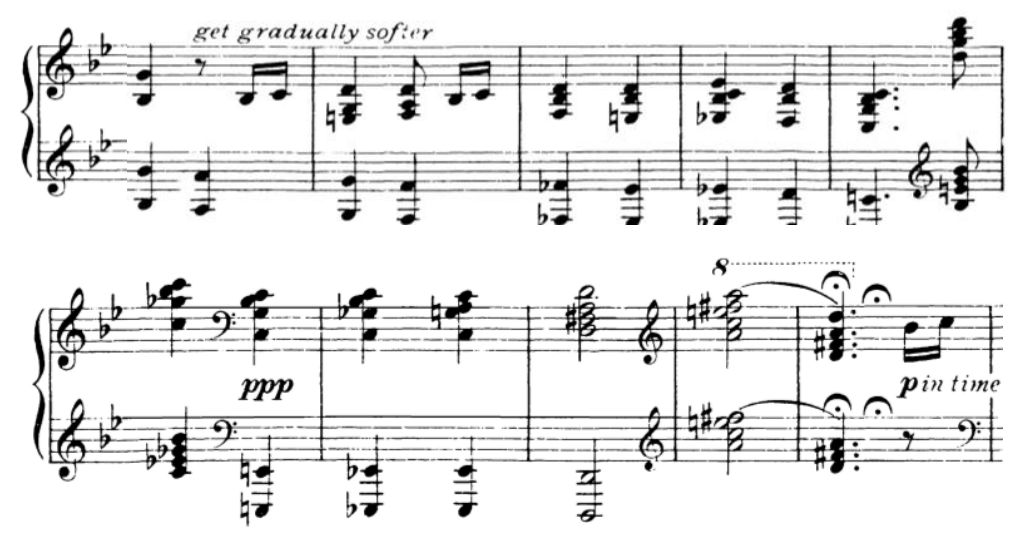

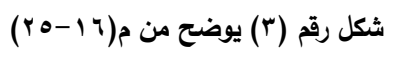

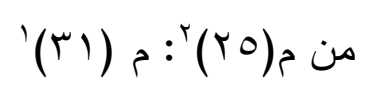

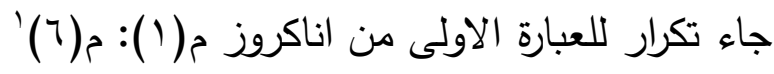

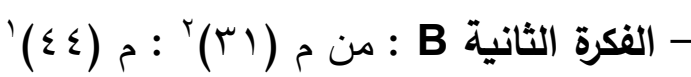

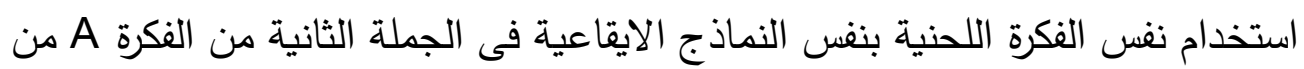

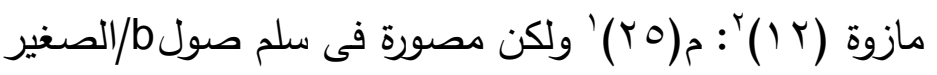

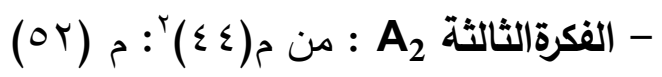

$$
\begin{aligned}
& \text { من م }
\end{aligned}
$$

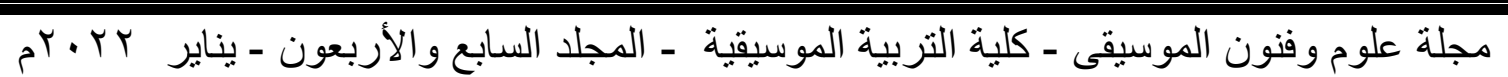




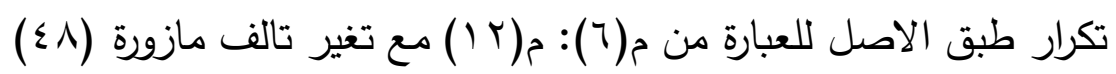
من م) ما(0)

قفلة هارمونية للمقطوعة فى اليدين بتألفات ثلاثية ورباعية .

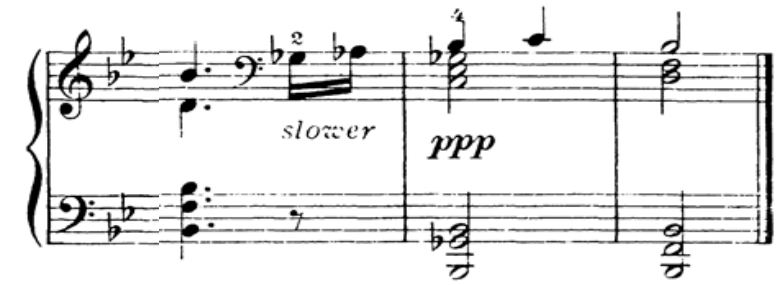

شكل رقم(؛) يوضح من م( •-0 r r)

الإيقتــاعـ"

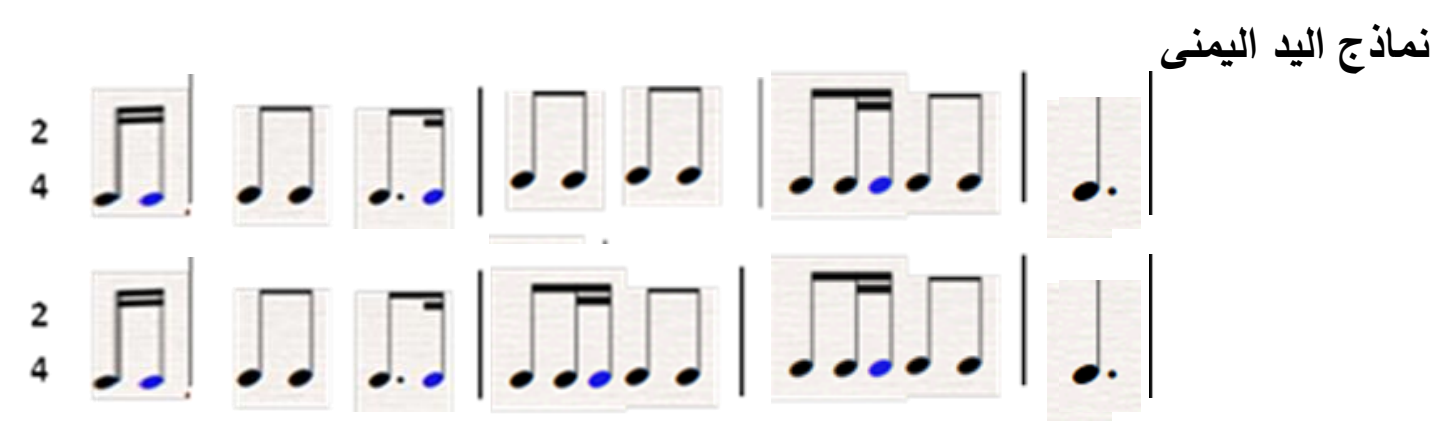

نماذج اليد اليسرى

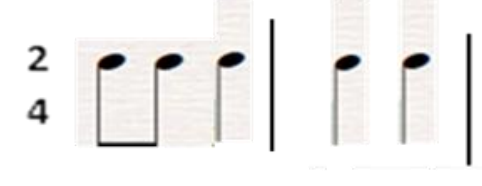

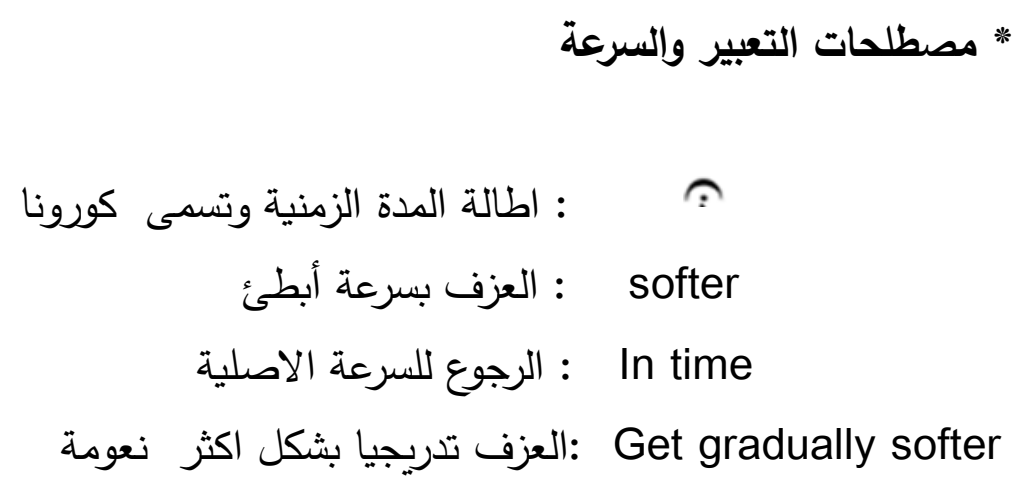

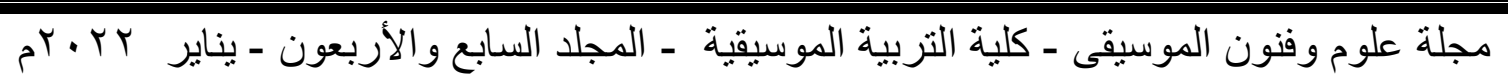




$$
\begin{aligned}
& \text { * التظليل الديناميكى } \\
& \text { : Pوت خافت P } \\
& \text { : صوت خافت جدا : PP } \\
& \text { صوت خافت جدا جدا قدر المستطاع : PPP }
\end{aligned}
$$

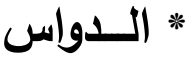

$$
\begin{aligned}
& \text { لا يوجد - ولكن اقترحته الباحثة في م رقم (ع ) لتسهيل الآداء . } \\
& \text { * الحليـات } \\
& \text { لا يوجد } \\
& \text { * التقنيات العزفية ومتطلبات آدئها }
\end{aligned}
$$

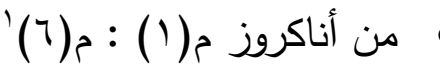

1- آداء لحن يغلب علية النغمات المزدوجة لمسافات لحنية مختلفة فى صوت السوبرانو يصاحبه نغمات سليمة فى صوت داخلى ونغمات مزدوجة في اليد اليسرى في شكل

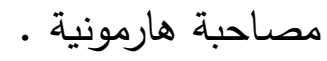

ويتطلب ادائها:

- اظهار اللحن الاساسي فى صوت السوبرانو باليد اليمني حتى لا يطنى عليه المصاحبة بالصوت الداخلى مع أهمية الإلتزام بترقيم الأصابع لسهولة الآداء .

- اللحن السلمي للصوت الداخلي في اليد اليمني يتطلب تجنب العزف السطحي، ونقل

$$
\text { الأصابع بسلاسة لتعطي الإحساس بعدم تغيير الأصابع • }
$$

- آداء النغمات المزدوجة في اليد اليسري بنفس القوة للنغتين مع عدم اظهار لحنهما بشدة حتي لا يطغي علي اللحن الأساسي في صوت السوبرانو في اليد اليمني •

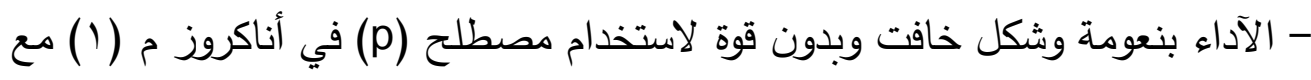

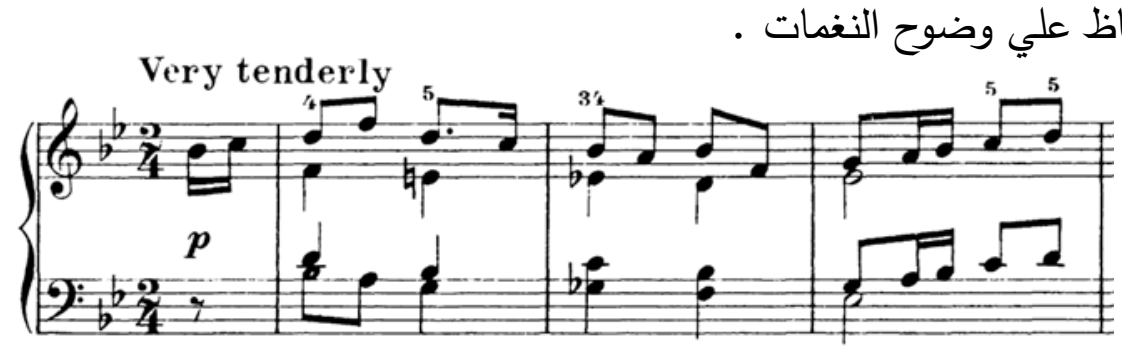

شكل رقم (•) يوضح لحن بنغمات مزدوجه

مجلة علوم وفنون الموسيقى - كلية التربية الموسيقية - المجلد السابع والأربعون - يناير بr ·rم 
ץ- آداء التآلفات الهارمونية فى مازوة رقم (؟) فى اليدين معا مع إطالة المدة الزمنية باستخدام

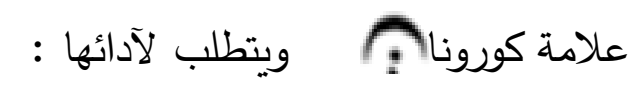

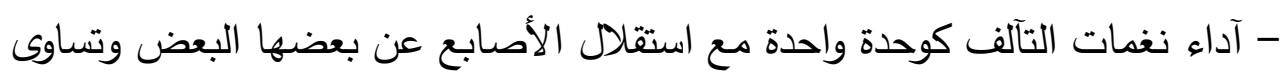

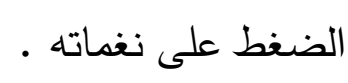

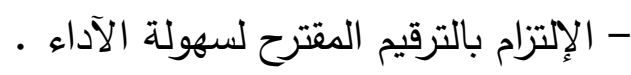

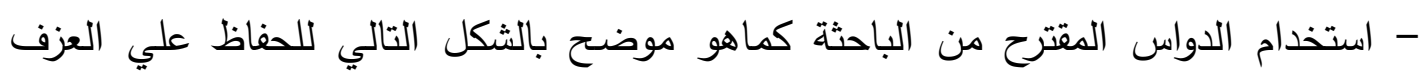

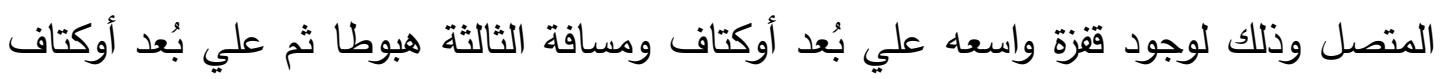

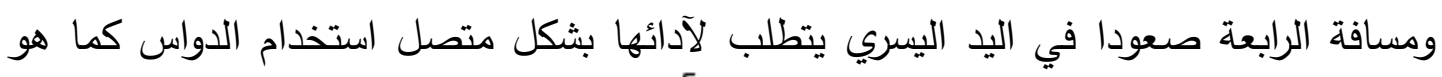

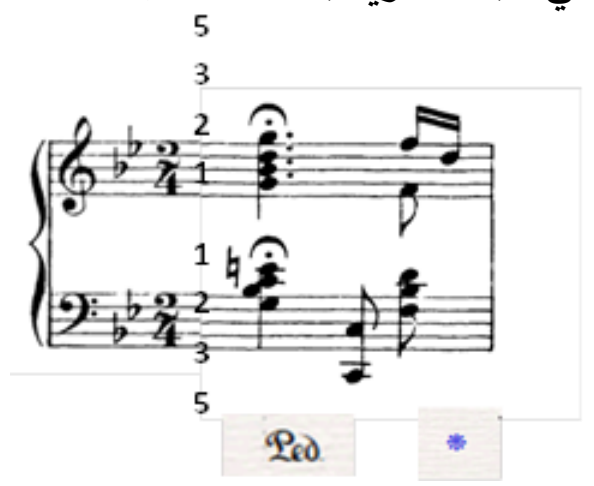

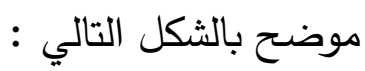

شكل رقم(؟) يوضح التآلفات واستخدام البدال المقترح

r - مراعاة بطئ السرعة في م (0) لاستخدام مصطلح Slower ثم الرجوع للسرعة الأصلية

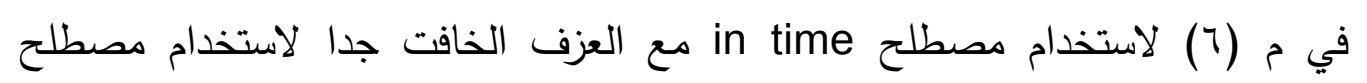

من م(؟) ' : م (ץ (1)' إعادة للعبارة من أناكروز م(1) : م(؟) وتتبع نفس الارشادات

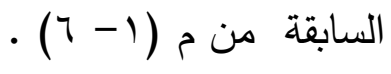

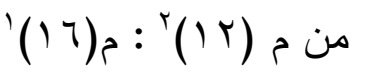

1- آداء الأوكتافات الهارمونية الكروماتية فى اليد اليسرى ويتطلب لآدائها:

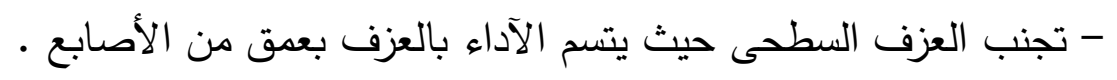

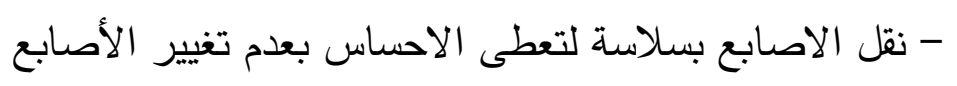


-الإلتزام بالترقيم المقترح من الباحثة مع مراعاة زحلقة الأصابع من الإصبع رقم (0) الي

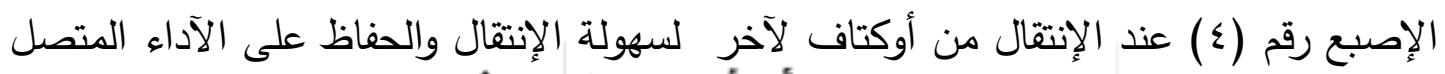

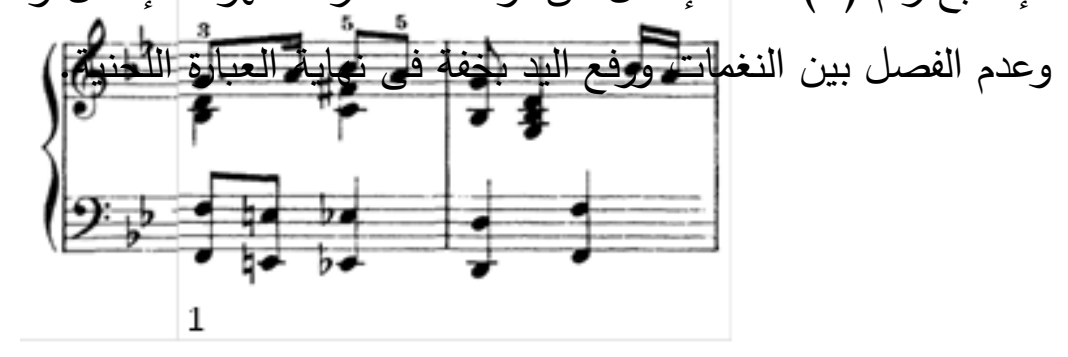

5'4

شكل رقم(V) يوضح مثال للأوكتافات الهارمونية الكروماتية

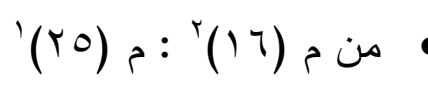

1 - آداء تالفات هارمونية من ثلاث و أربع نغمات ويراعى عند آدائها اتباع الارشادات السابقة

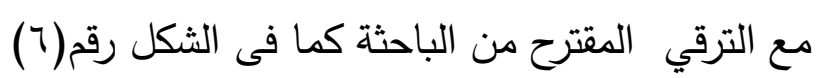

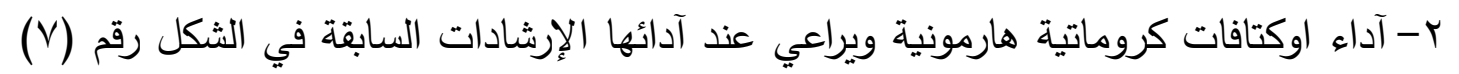

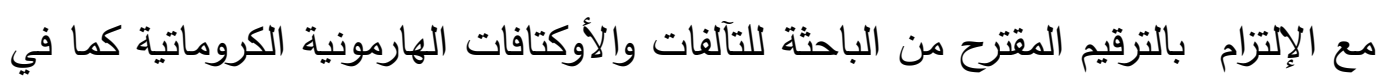

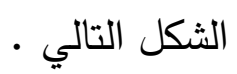

get graduallty) بر-براعي الخفة والنعومة في العزف بثكل تدريجي لاستخدام التعبير

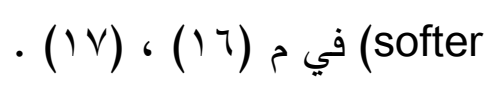

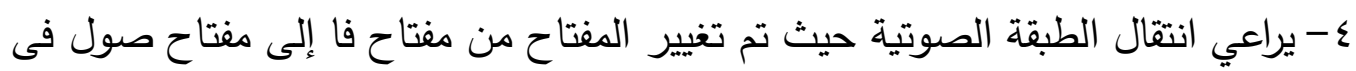

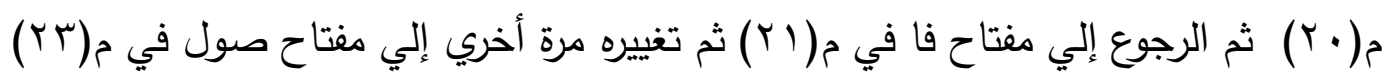

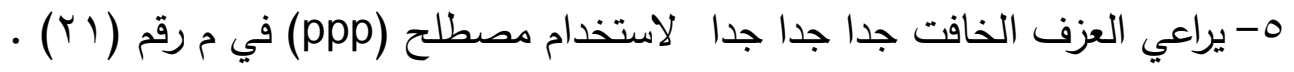

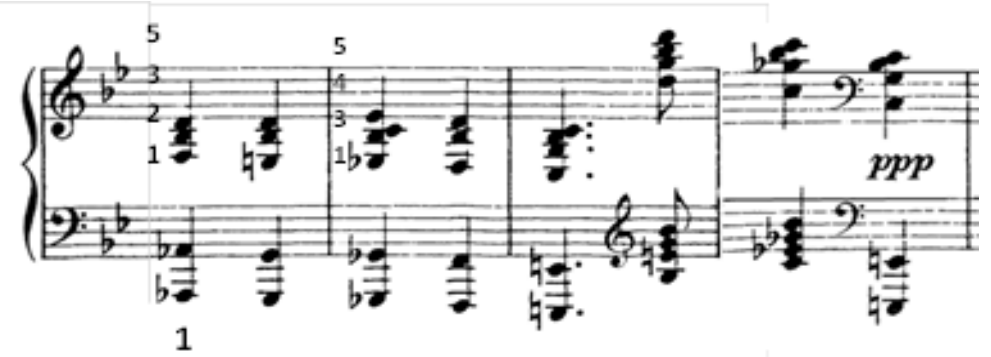

$5 ' 4$

شكل رقم(م) يوضح تنيير المفاتيح والتزقيم المقتح للتآلفات والأوكتافات

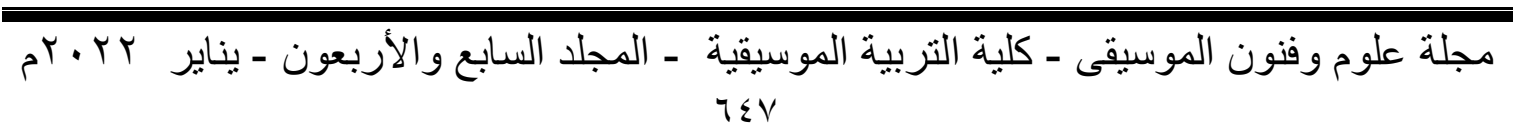


Y- يراعي عزف النغمات أوكتاف أعلى لوجود علامة مه فى م رقم (؟ ب) .

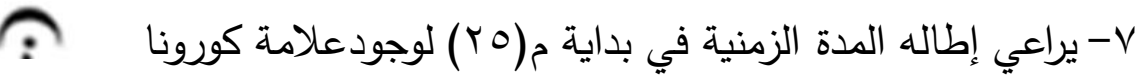

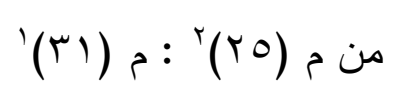

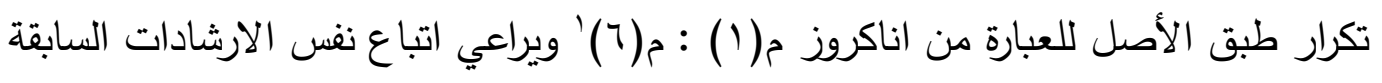

$$
\begin{aligned}
& \text { كما في الثكل رقم (0) • }
\end{aligned}
$$

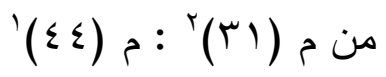

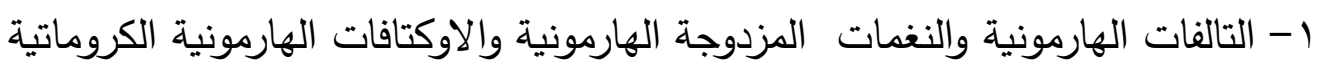

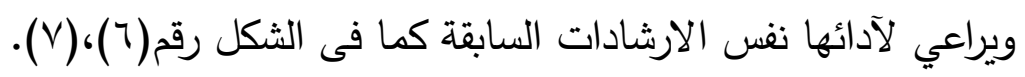

r-مراعاه تغيير دليل السلم فى بداية م (rr)

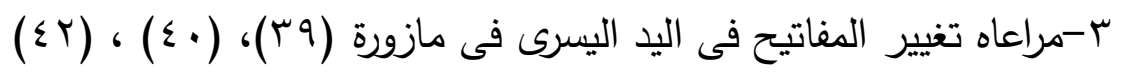

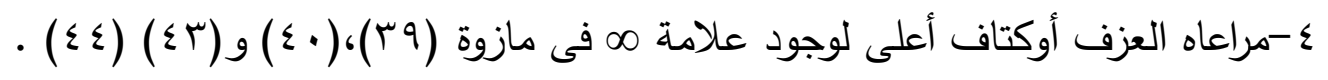

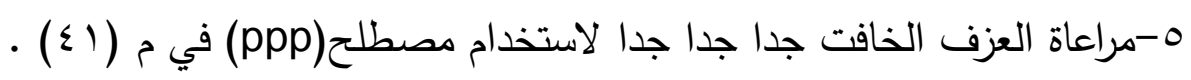

$$
\text { من م (Or) }
$$

1- تكرار طبق الأصل للعبارة من م(1-7) مع تغيير القفلة ويجب مراعاه نفس الإرشادات

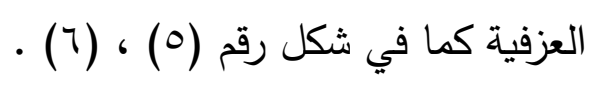

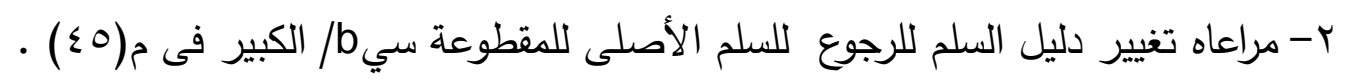

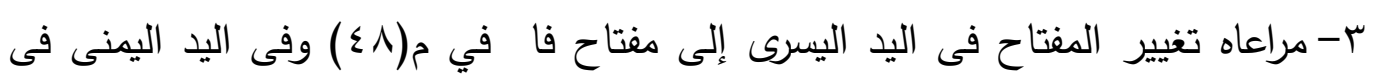

$$
\text { (0.) }
$$

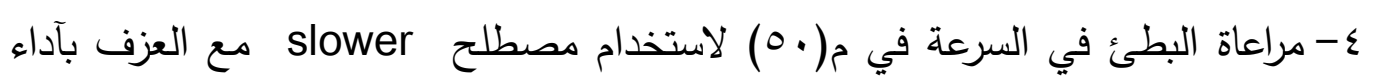

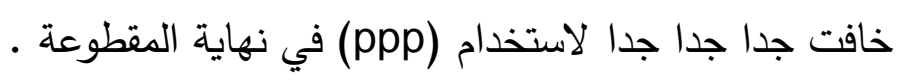




\section{المقطوعة الثانية}

The Forest grandeur عظمة|لغابة

( رقم ' فى ألبوم مقطوعات الغابة/لاسترالية)

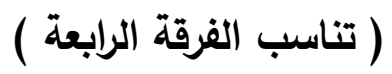

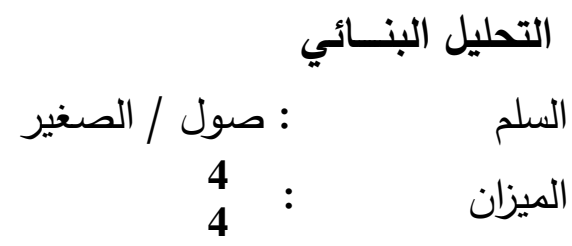

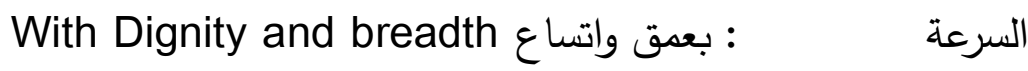

$$
\begin{aligned}
& \text { الطول البنائي : بr مازورة }
\end{aligned}
$$

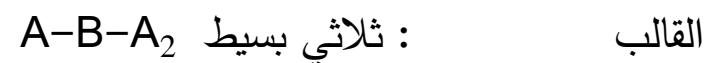

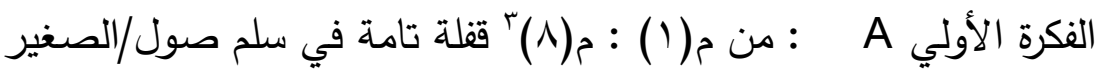

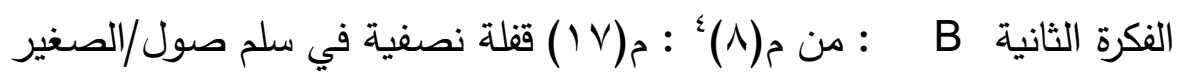

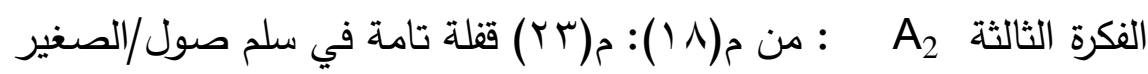

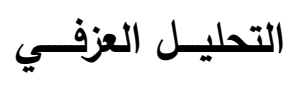

"اللحن والمصاحبه

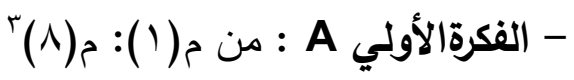

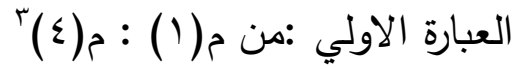

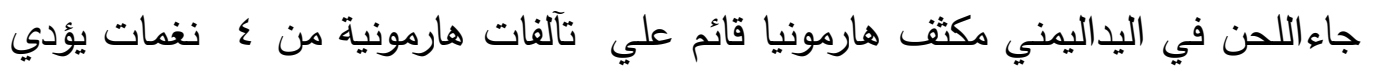

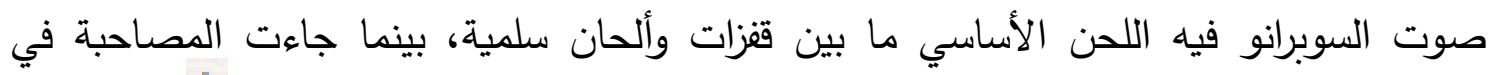

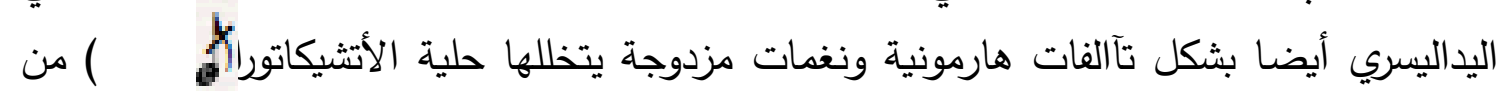

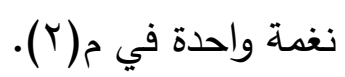

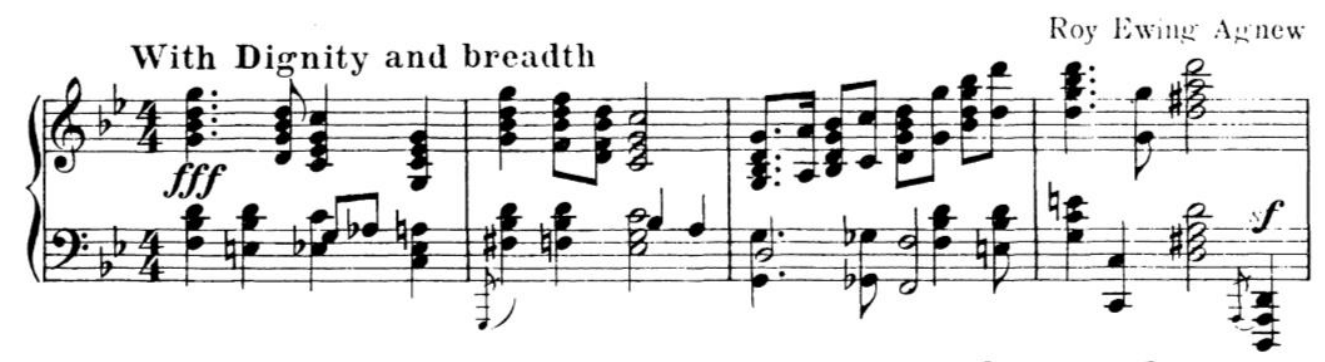

شكل رقم(9) يوضح من م(1-\{)

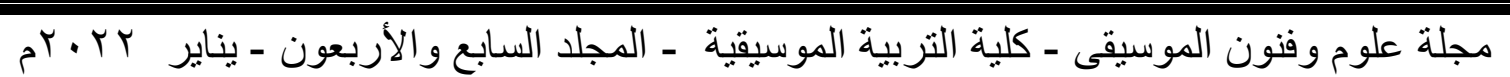




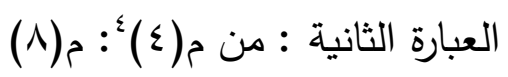

تكرار العبارة السابقة في اليد اليمني مع تغيير القفلة في م (^) واختلاف اليد اليسرى فقط

في م(7) ونغمات بسيطة في القفلة أيضا.

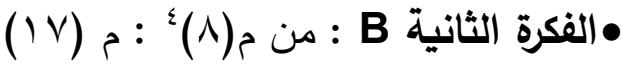

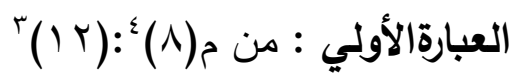

جاء اللحن الأساسي في اليد اليمني علي شكل تآالفات هارمونية من ب ، ؛ ؛ نغمات حيث يظهر اللحن في شكل سلمي وقفزات في صوت السوبرانو يتخلله علامات تحويل وحلية الأتثيكاتورا

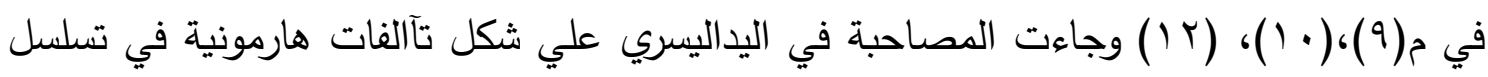

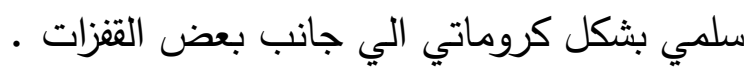

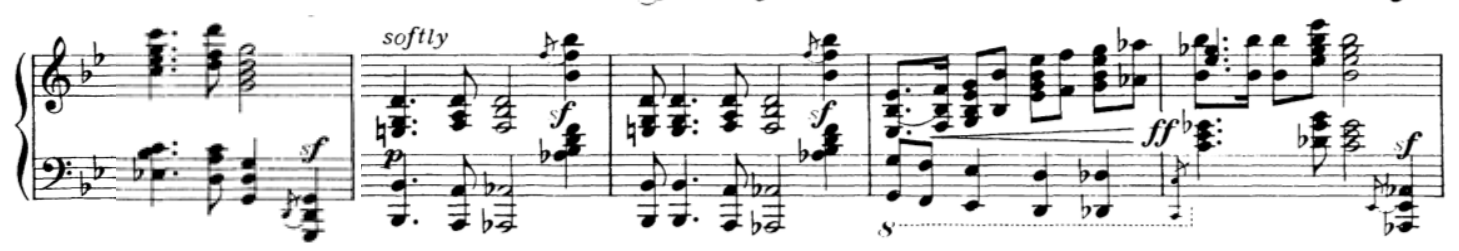

$$
\text { شكل رقم( · (1) يوضح من م(1- ا I ) }
$$

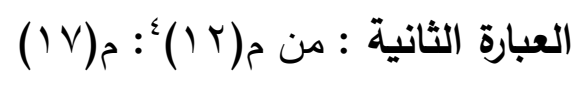

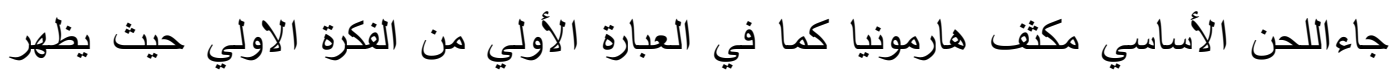
اللحن الأساسي في أصوات السوبرانو من تآلفات الهارمونيةمع التغيير الكثيف لعلامات التيات التحويل في م(ع () وجاءت المصاحبة هارمونية أيضافي تسلسل سلمي وقفزات كبيرة يتخللهاحلية

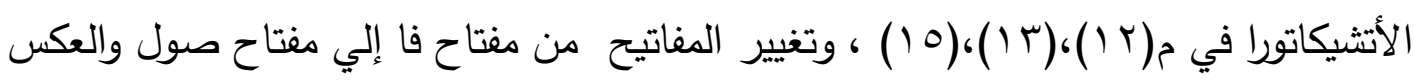
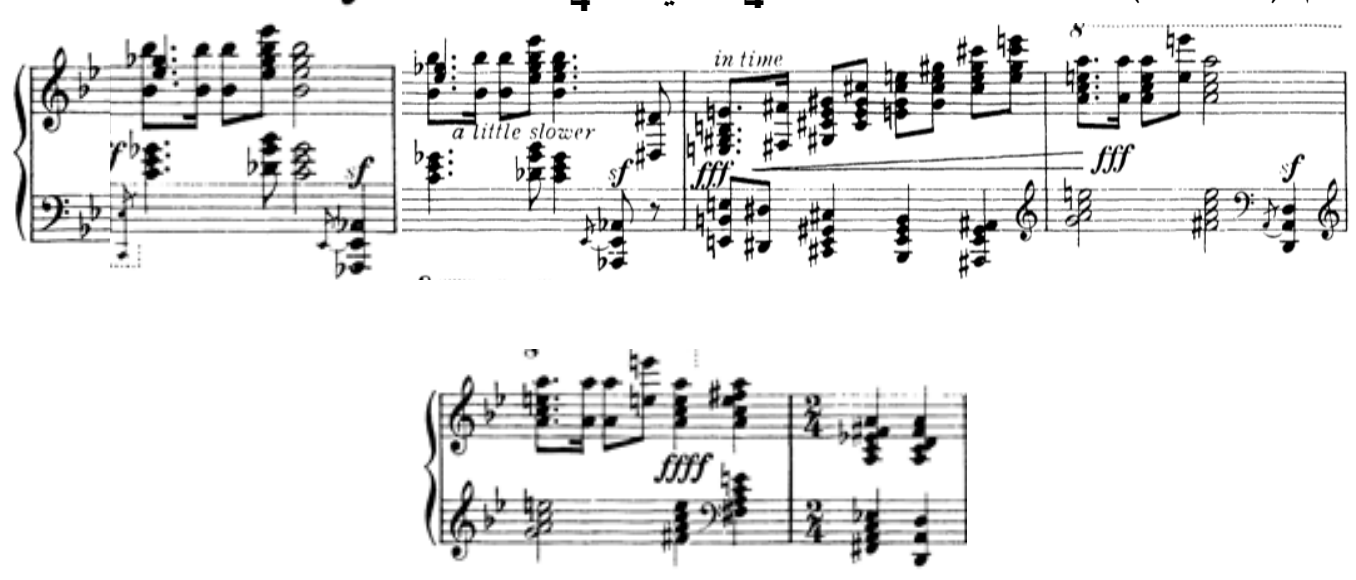

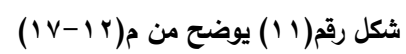

مجلة علوم وفنون الموسيقى - كلية التربية الموسيقية - المجلد السابع والأربعون - يناير بr ·r مج 70. 


$$
\text { الفكرة الثالثة A }
$$

جاءت في عبارة مطولة مكونة من 1 موازير تكرار لنفس لحن العبارة الأولي من

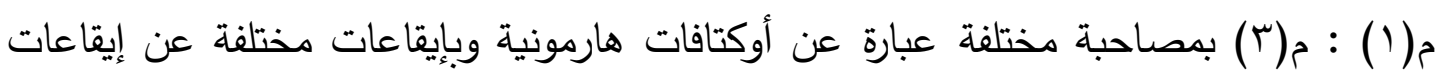

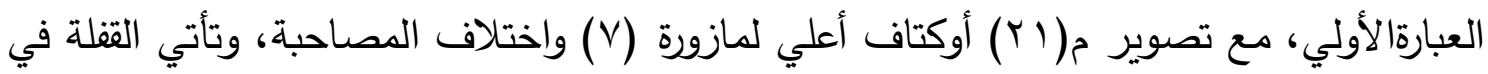

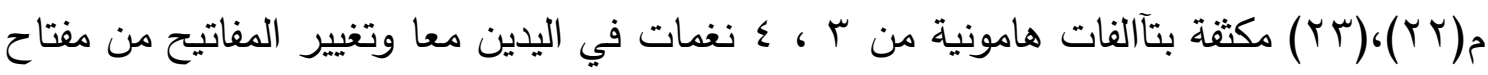

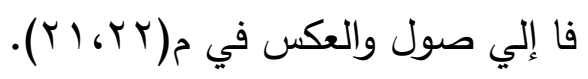

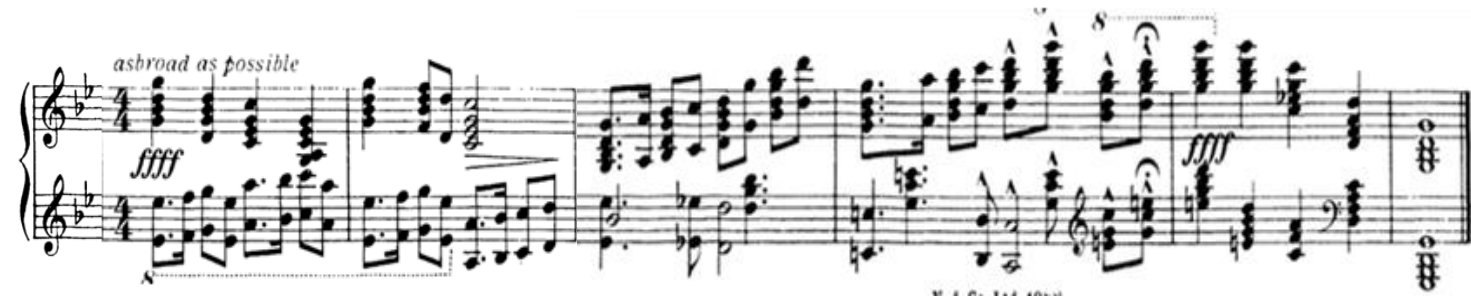

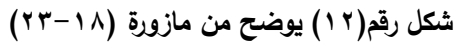

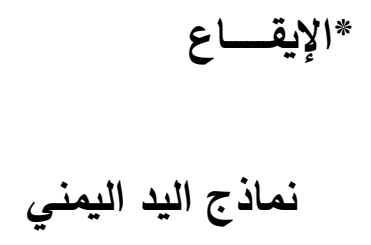
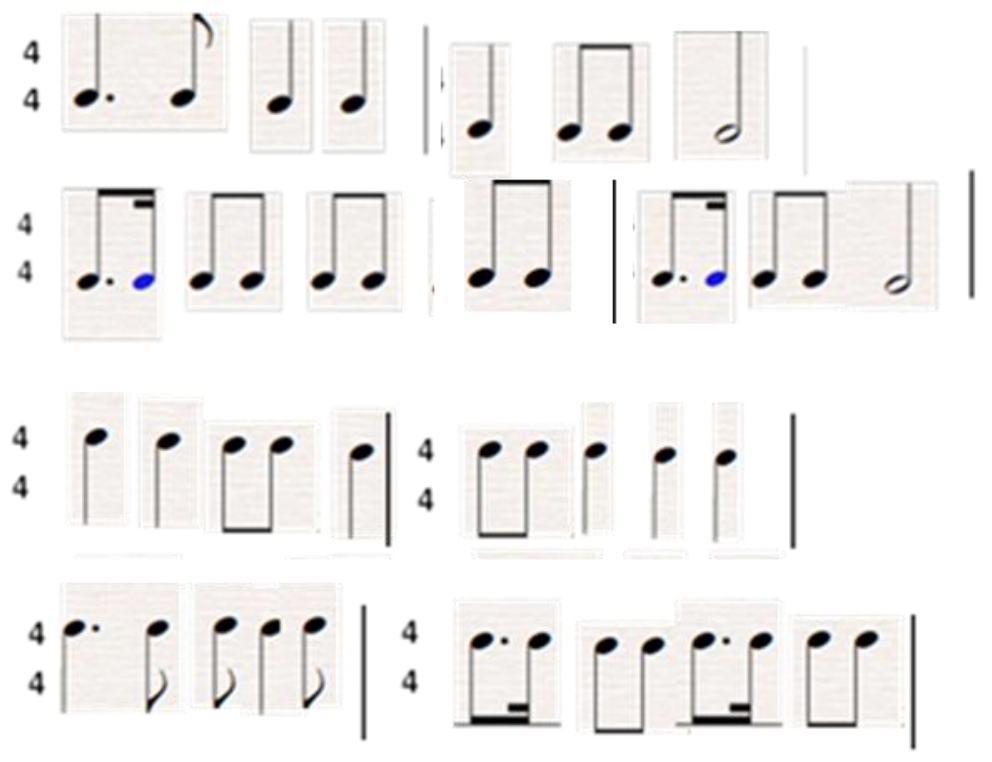

نماذج اليد اليسري

* مصطلحات التعبير والسرعة * م A little slower الرجوع للسرعة الأصلية مرة أخري : In time as board as possible 


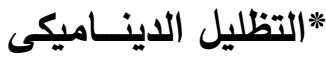

$$
\text { : إلبراء : الآداء بمنتهي القوة الصوت فجأة }
$$

fff

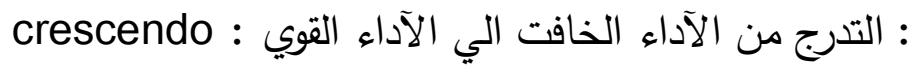
diminuendo: التّرج من الآداء القوي إلي الآداء الضعيف :

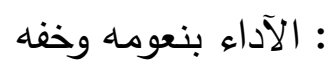

كريشندو

ديمنويندو

Softly

الـدواس " (الـ

لا يوجد - ولكن اقترحته الباحثة لتسهيل الآداء والعزف المتصل للتآالفات .

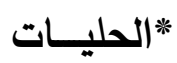

$$
\text { * التقرت حلية الأتثكاتورا في اليد اليمني واليسري العزئة ومتطات آدئهات }
$$

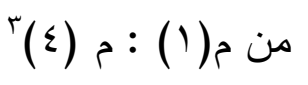

1- تآالفات هارمونية من أربع نغمات في اليد اليمني قائم عليها لحن المقطوعة وتقترح الباحثة

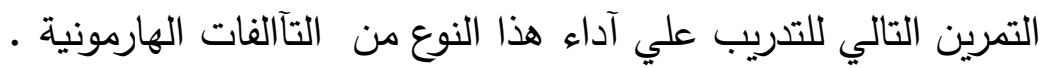

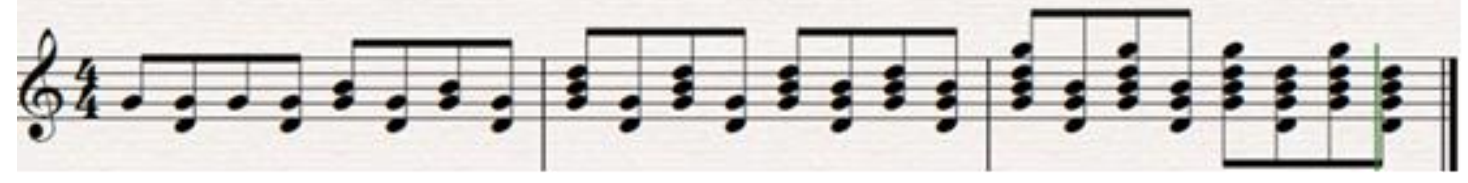

شكل رقم (ז') تمرين مقترح رقم (1) للتتريب علي آداء التآلفات الهارمونية

$$
\text { ويراعي لآدائها: }
$$

- عزف نغمات التآآلفات الهارمونية بقوة لمس واحدة بحيث لايطغي صوت إحدي نغمات

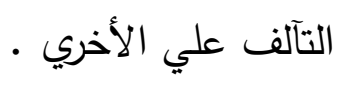

- اظهار نغمة السوبرانو في التآلف قدر المستطاع لانها تعتبر اللحن الاساسي للمقطوعة .

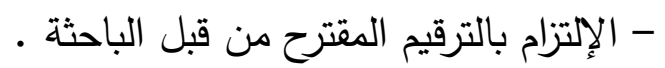

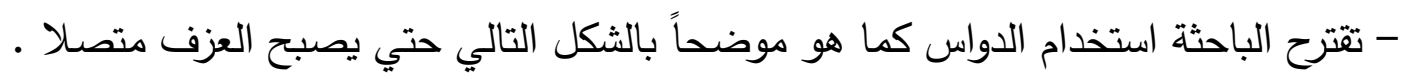

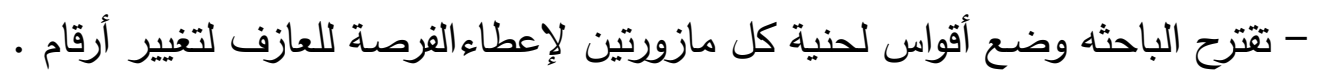


الأصابع والإنتقال من طبقة صوتية لأخري كما هو موضح بالثكل التالي.

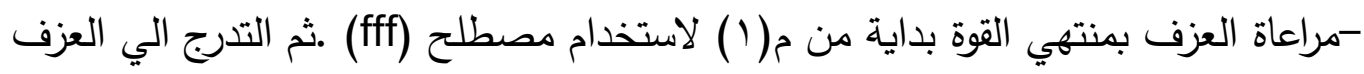

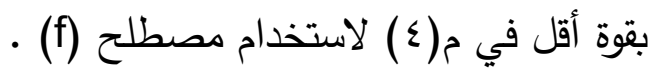
-مراعاة تثبيت النغمات الداخلية في اليد اليسري وعدم ترك النغمة إلان بانتهاء زمنها كما في نغمة (ري) بإيقاع البلانش في م (r) •

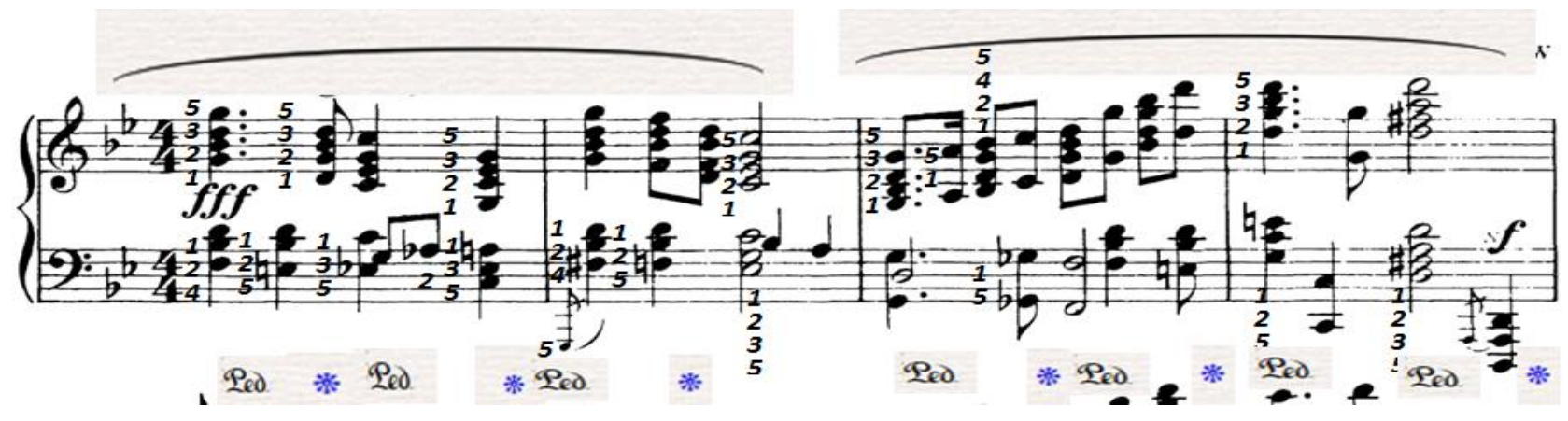

شكل رقم(ع (1) يوضح من م(1-؛) مع اقتراح الدواس والأقواس اللحنية

r- حلية الاتثيكاتورا في اليد اليسري في م (Y) ولآدائها يجب مراعاة أن تأخذ الحلية قيمتها

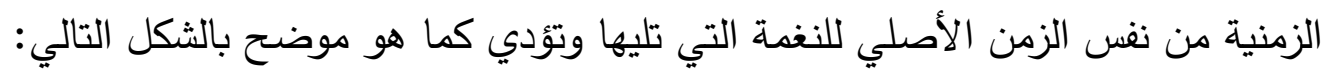

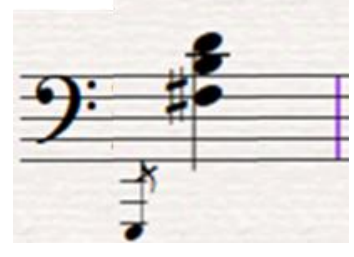

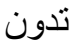

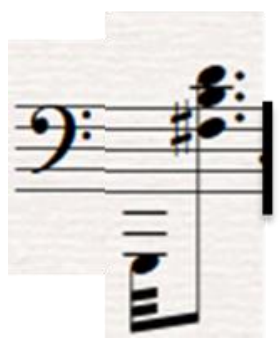

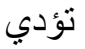

شكل رقم(0 ) يوضح حلية الأتثيكاتورا وكيفية آدائها

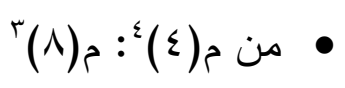

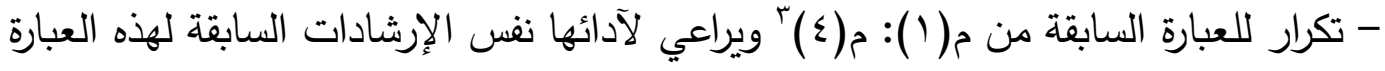

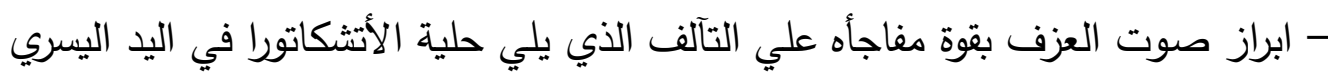

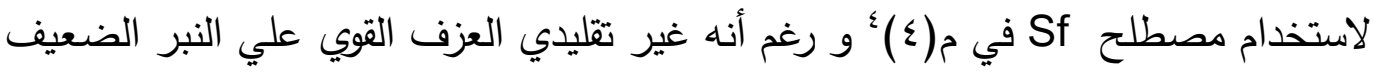




$$
\begin{aligned}
& \text { ولكنها كانت سمة هذه المقطوعة . } \\
& \text { من م(^) }
\end{aligned}
$$

1- تآلفات هارمونية في اليد اليمني ويراعي نفس الإرشادات السابقة لآدائها كما في شكل

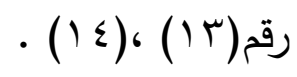

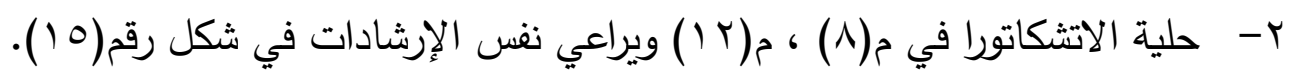
r- المصاحبة في اليد اليسري قائمة علي تسلسل سلمي لأوكتافات هارمونية ويراعي لآدائها : - العزف بقوة متساوية بحيث لايطغي صوت إحدي النغمات علي الأخري

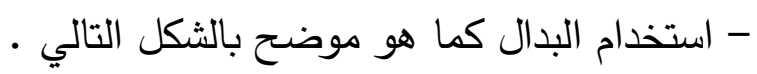
- الإلتزام بالترقيم الكقترح من قبل الباحثة لتسهيل العزف.

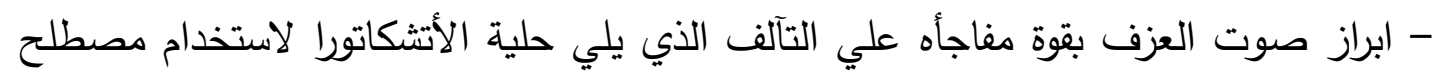

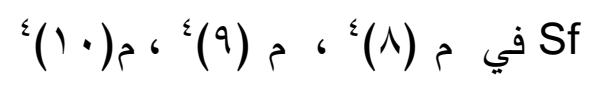

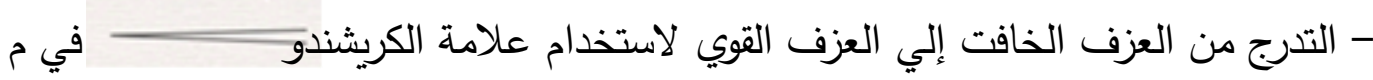

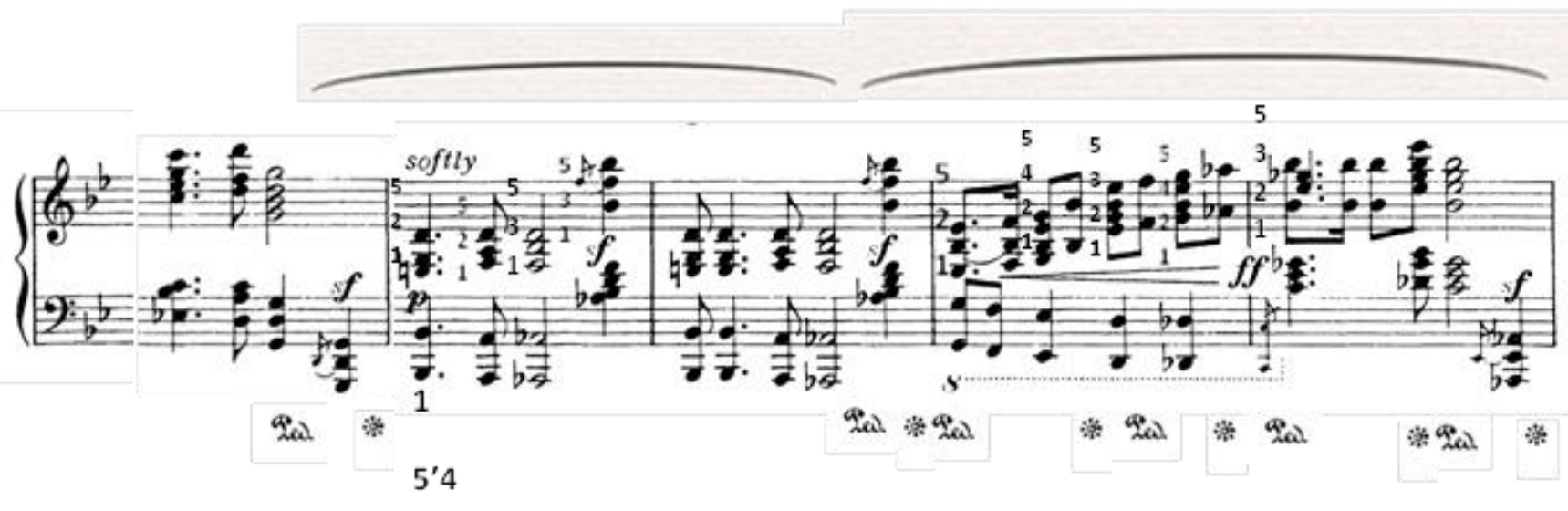

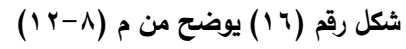

$$
\text { من م (IV) }
$$

1- تآلفات هارمونية في اليد اليمني واليسري ويراعي نفس الإرشادات السابقة لآدائها كما في

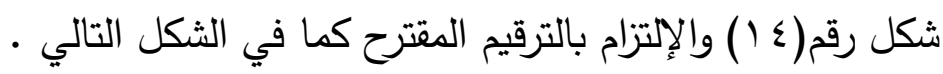

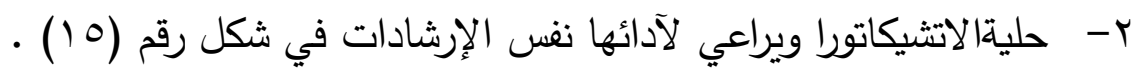

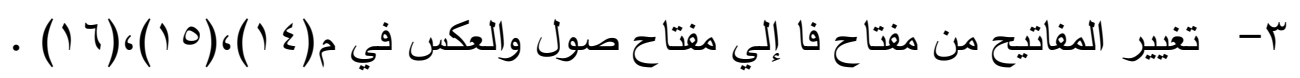

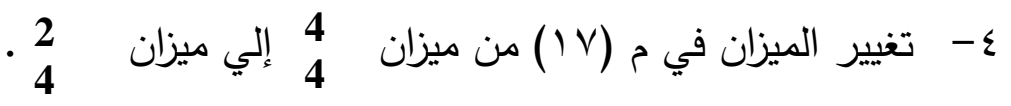

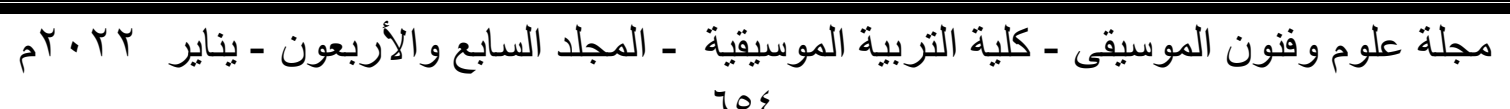




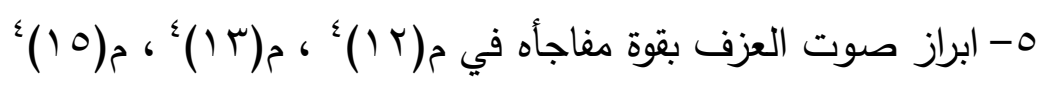

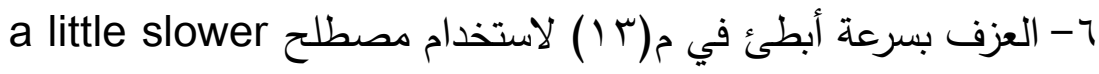

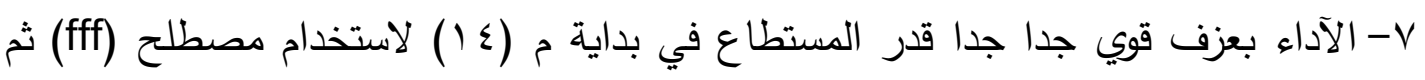

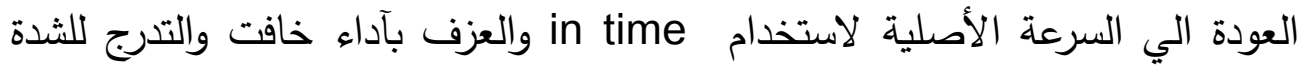

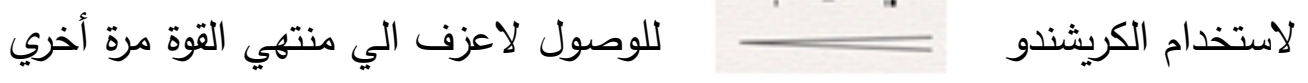
في بداية م (10) لاستخدام مصطلح (fff) . والعزف بقوة أكبر من ذلك في لاعزي لاعني

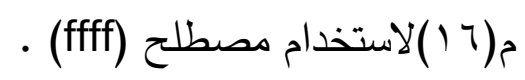

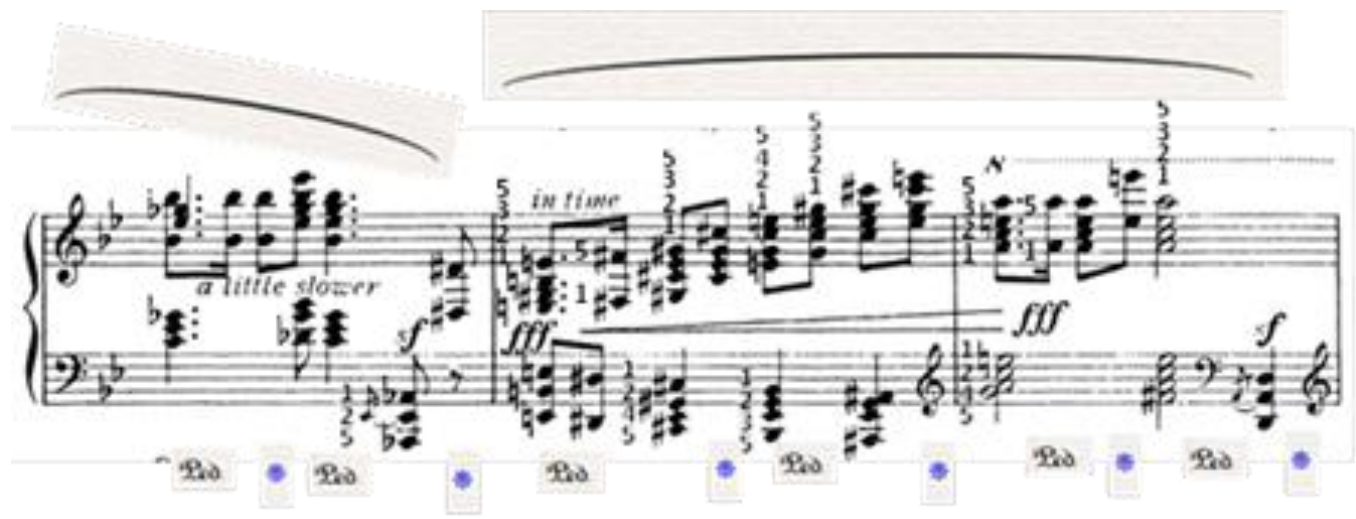
شكل رقم (IV) يوضح من م(Y IV_)

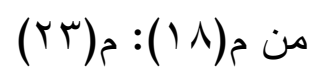

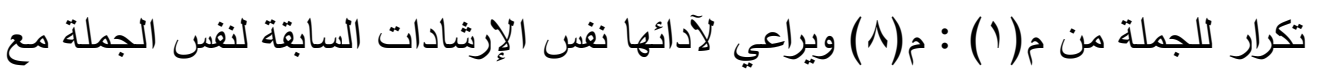
مراعاة :

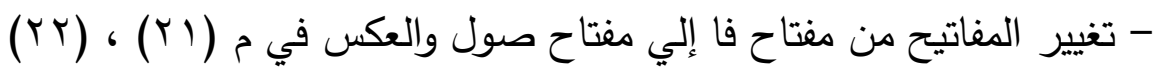

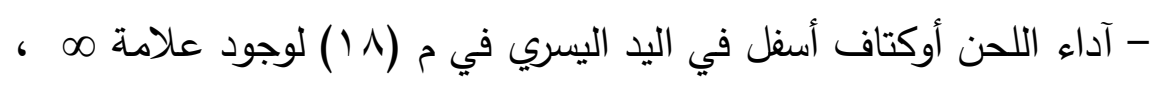

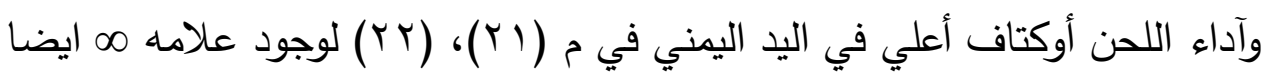

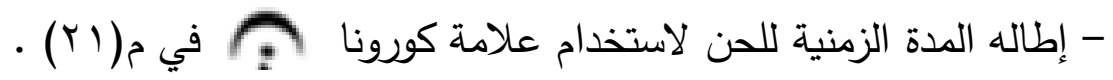

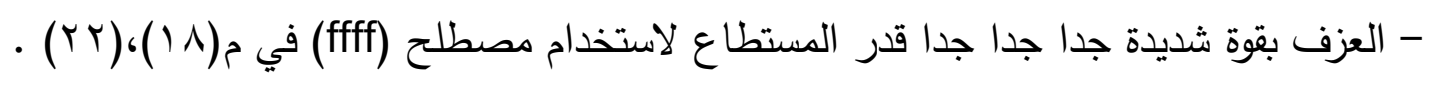


مقطوعة رقم ب جولة الذهاب

THE MERRY - GO - ROUND

رقم (1) من الألبوم خيالات شبابية

(تناسب الفرقة|لثانية)

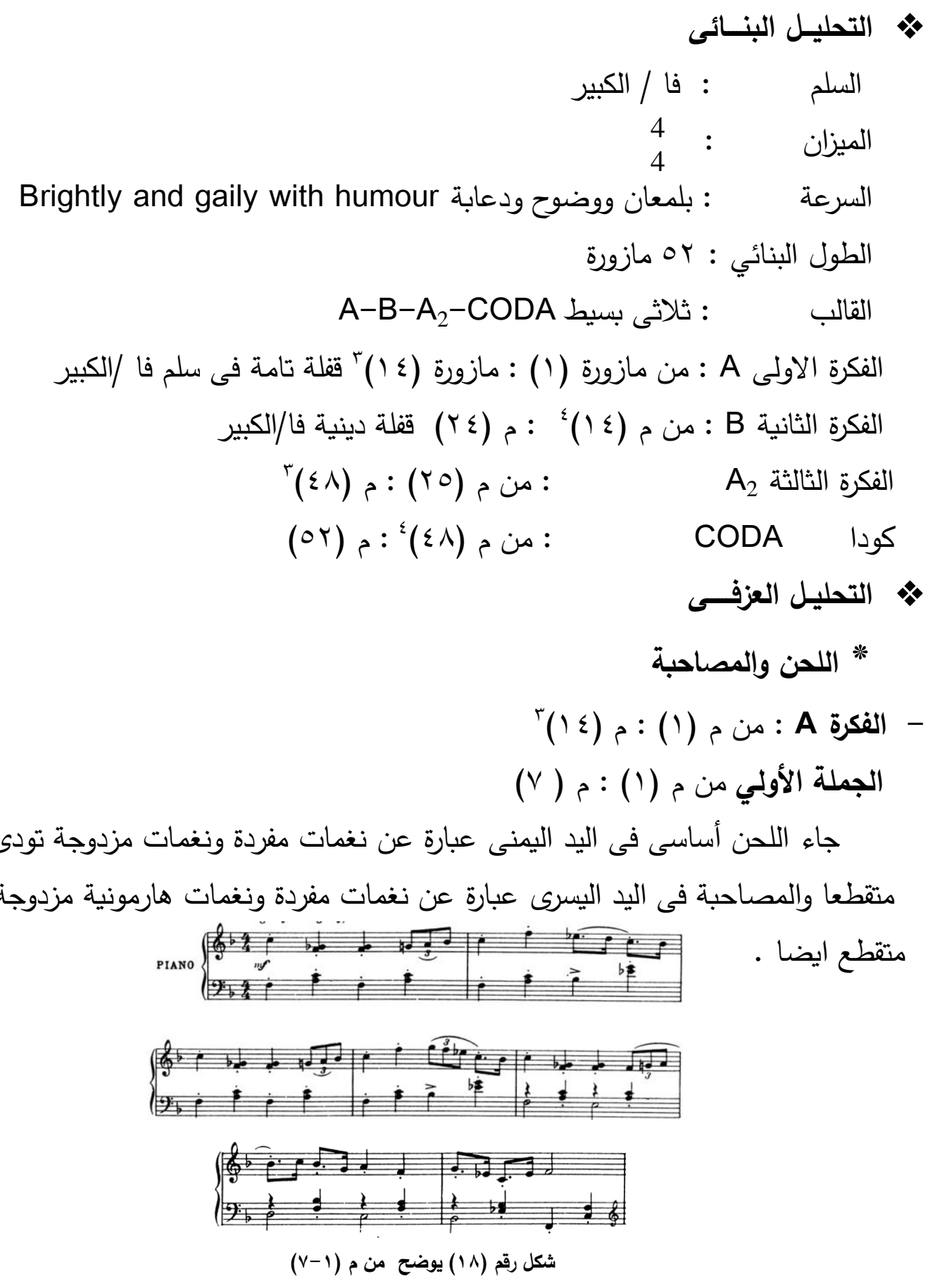

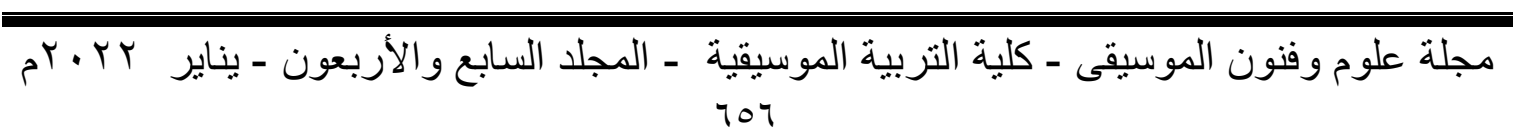




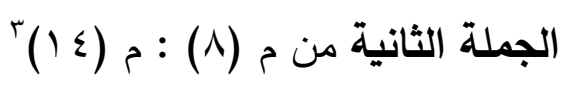

نفس اللحن فى الجملة السابقة ولكن مصور على بعد أوكتاف أعلى ولكن اختلفت

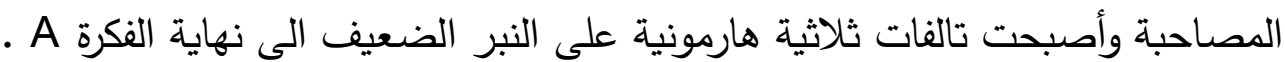

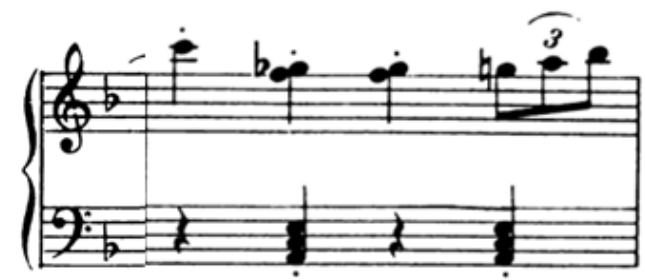

شكل رقم (9 1 ) يوضخ اختلاف المصاحبه في اليد اليسري

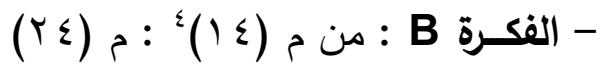

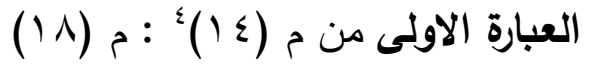

جاء اللحن فى اليد اليمنى بشكل سلمى صاعد وهابط متصل والمصاحبة نغمة ممتدة فى

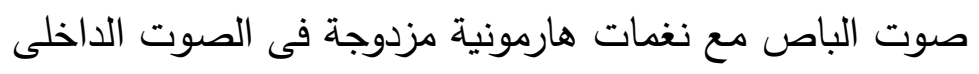

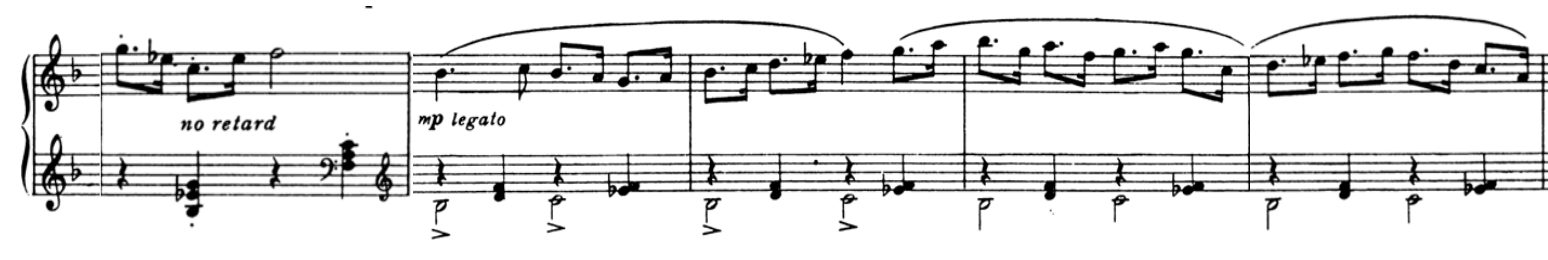

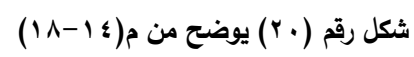

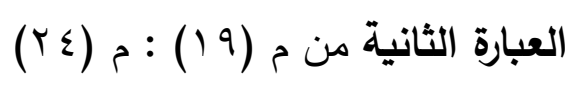

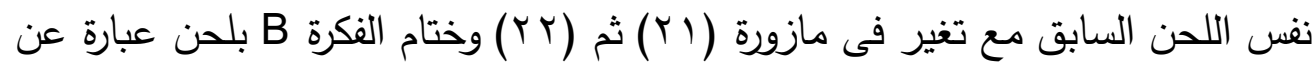
نغمات هارمونية مزدوجة ونغمات مفردة بينما أخذت المصاحبة نفس الثكل العبارة الاولى ثماتم

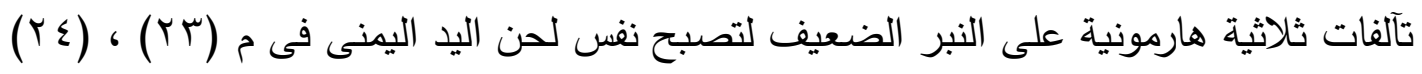

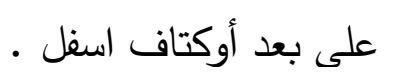

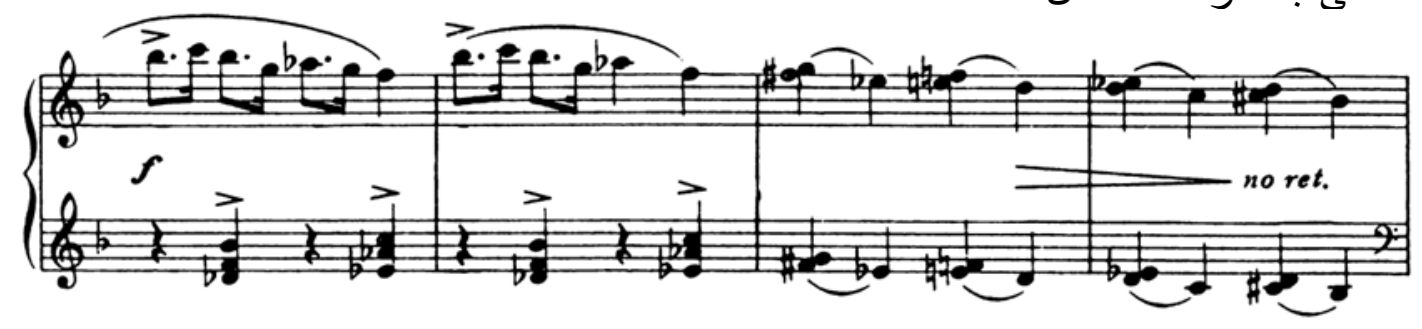

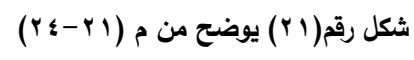

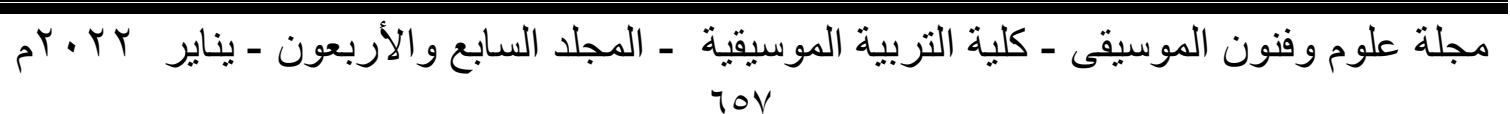




$$
r(\text { الفكرة }
$$

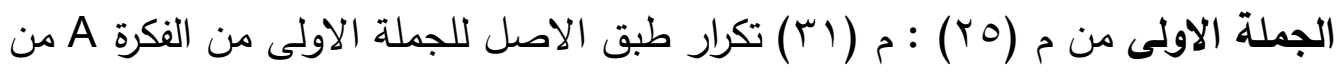

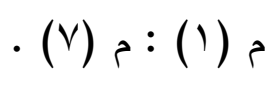

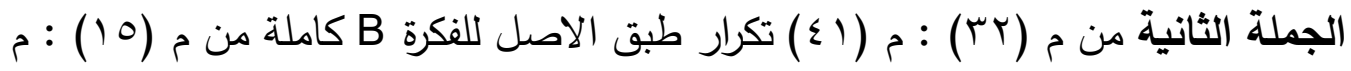

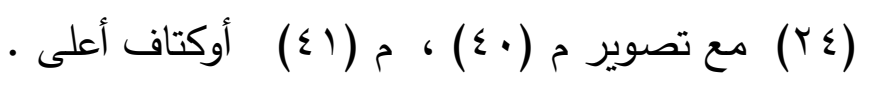

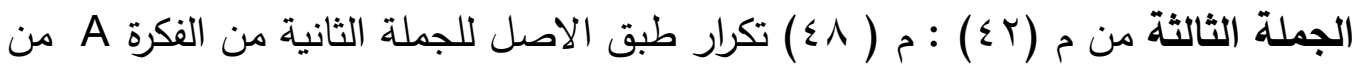

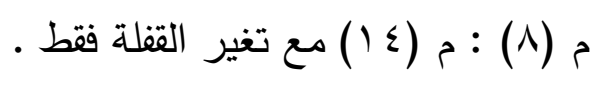

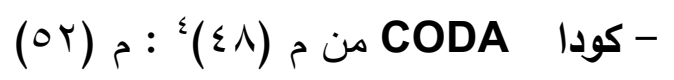

كودا هارمونية فى اليدين حيث نغمات هارمونية مزدوجة فى اليد اليمنى واليسري

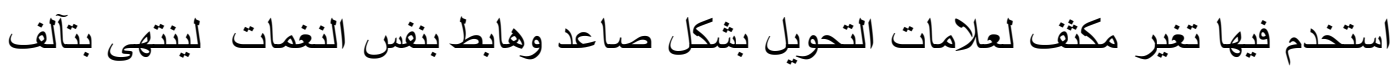

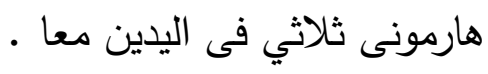

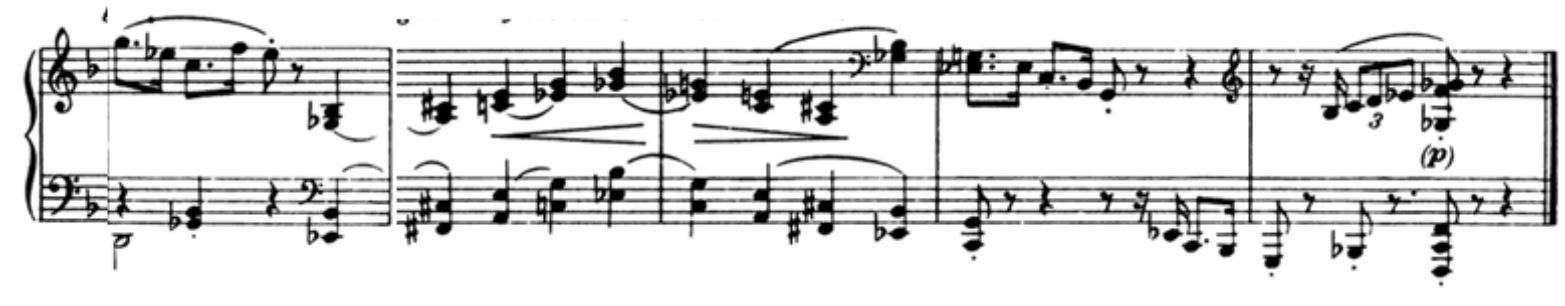

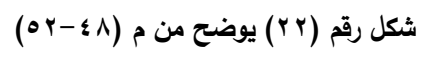

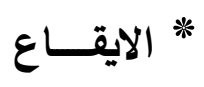

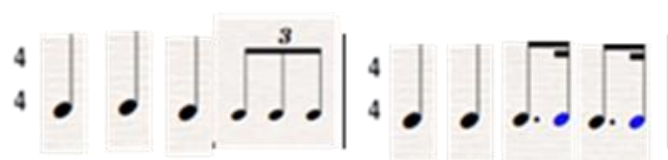

نماذج اليد اليمنى

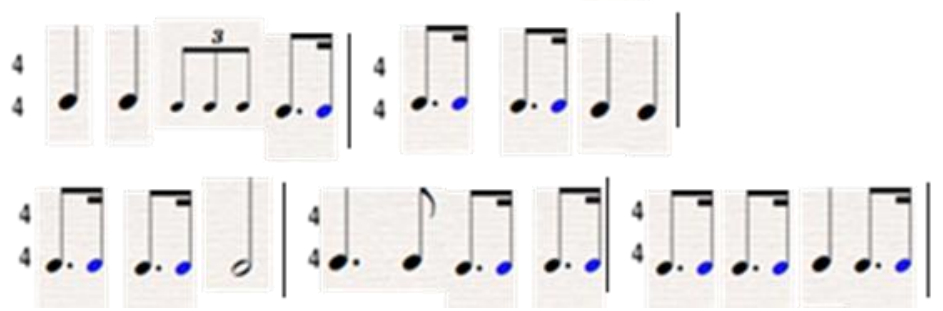

مجلة علوم وفنون الموسيقى - كلية التربية الموسيقية - المجلد السابع والأربعون - يناير بr •r مب 701 
نماذج اليد اليسرى

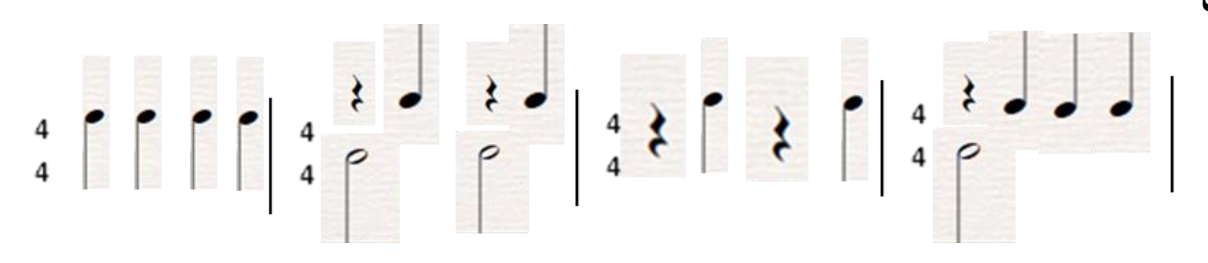

$$
\text { * - }
$$

Gradually slower and more deliberate to the end -

$$
\begin{aligned}
& \text { عزف بشكل أبطئ وبتآني إلى النهاية } \\
& \text { * التظليل الدينا ميكى } \\
& \text { : صوت متوسط القوة } \\
& \text { MF - }
\end{aligned}
$$

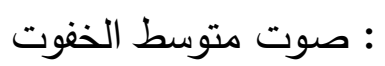

$$
\begin{aligned}
& \text { MP - }
\end{aligned}
$$

diminuendo : تتاقض شدة الصوت تدريجيا :

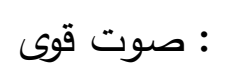$$
\text { F - }
$$

crescendo : زيادة شدة الصوت تدريجيا :

$$
\text { : موت خافت : }
$$

: - (بر قوى على النغمة

MF -
MP -

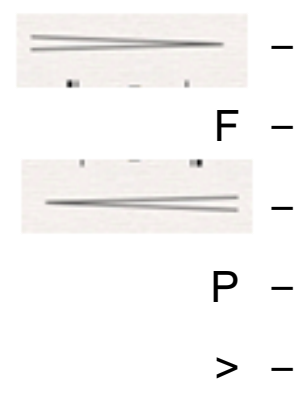

$$
\begin{aligned}
& \text { * الاواس الحليات } \\
& \text { *لايوجد }
\end{aligned}
$$

* التقنيات العزفية ومتطلبات ادائها

$$
\begin{aligned}
& \text { من م (1) : م (ع) (1) } \\
& \text { (v) }
\end{aligned}
$$


1 - آداء نغمات متقطعة مفردة ومزدوجة فى اليد اليمنى واليسرى كما في الثكل التالي :

$$
\text { ويتطلب ادائها : }
$$

- أن تأتى الحركة من أعلى الى أسفل بوزن ثقل الذراع وباستدارة كاملة من أصابع اليد

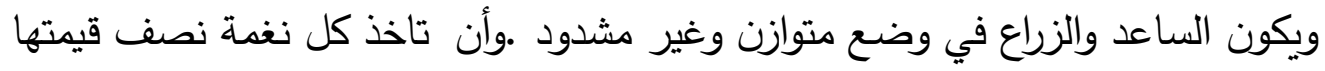

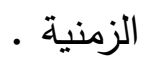

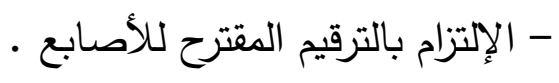

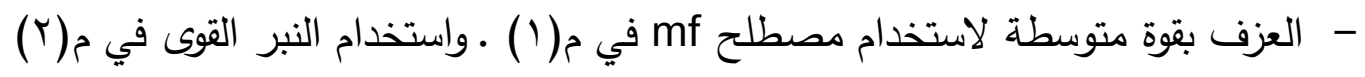

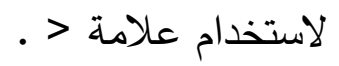

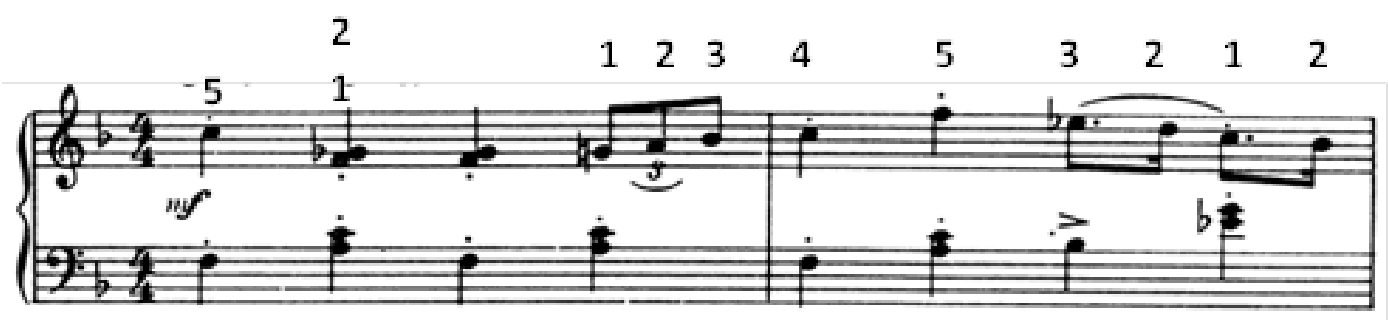

شكل رقم(Yr) يوضح النغمات المتقطعة المفردة و المزدوجة

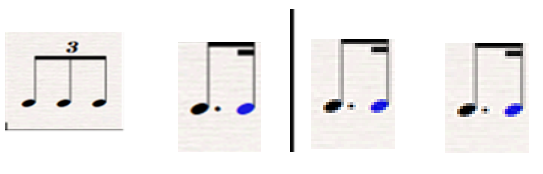

r- اداء لحن سلمى متصل legato على إيقاع

$$
\text { ويتطلب ادائها : }
$$

- عدم الفصل بين النغمات ورفع الأيدى بخفة فى نهاية القوس اللحني .

$$
\text { - - الإلتزام بالترقيم المقترح - }
$$

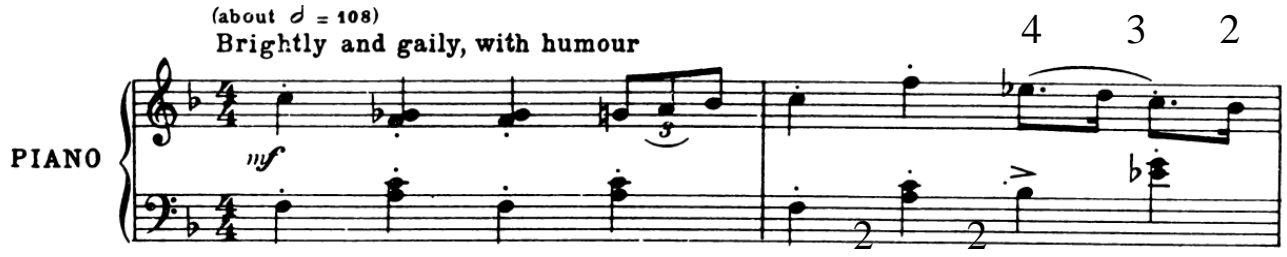

$$
\begin{array}{llllllllllll}
5 & 1 & 1 & 1 & 2 & 3 & 4 & 5 & 5 & 4 & 3 & 2
\end{array}
$$

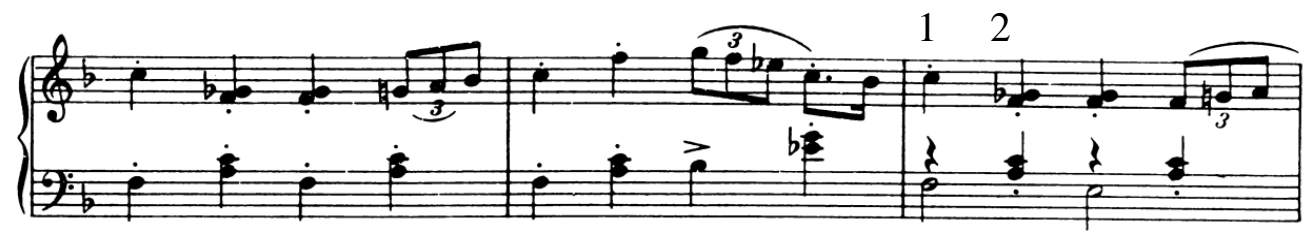

$$
\text { شكل رقم (؟ Y) يوضح اللحن السلمي والترقيم والمقترح }
$$

مجلة علوم وفنون الموسيقى - كلية التربية الموسيقية - المجلد السابع والأربعون - يناير بr.ب .بم 


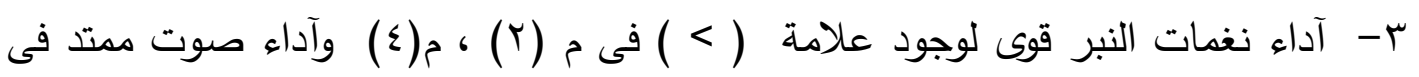

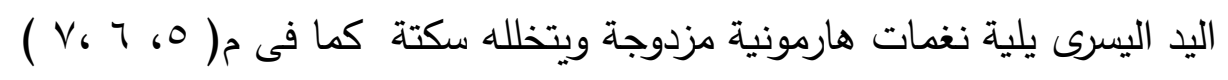
ويراعى لادائها :

- تثبيت النغمة الممتدة على إيقاع البلانش فى اليد اليسري ثم عزف النغمات الهارمونية
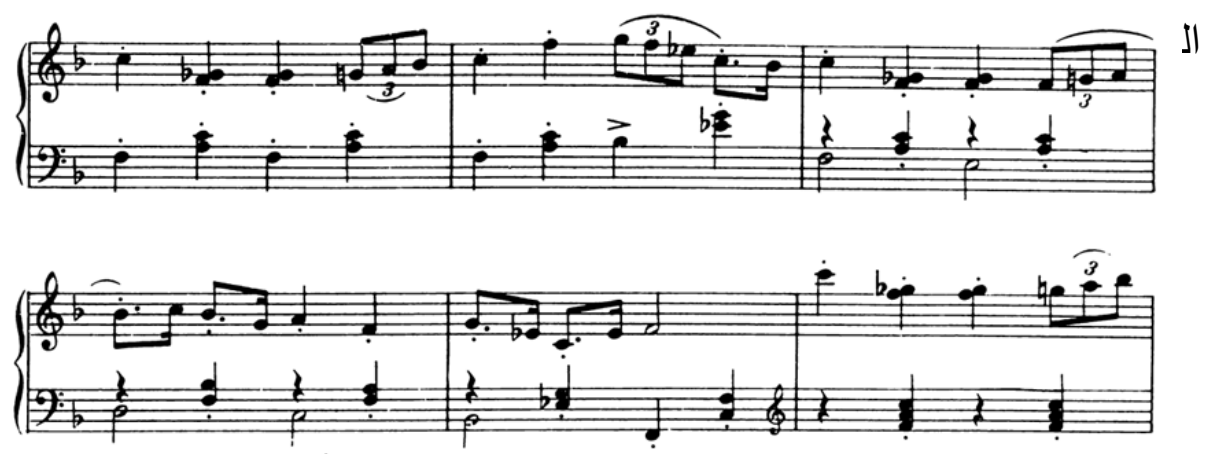

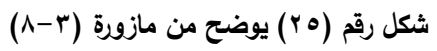

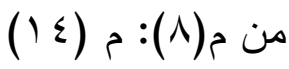

1 - تكرار للجملة الاولى على بعد اوكتاف أعلى تتبع فية نفس الارشادات السابقة

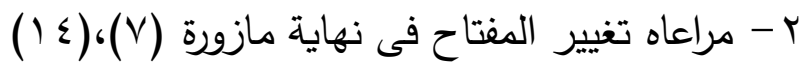

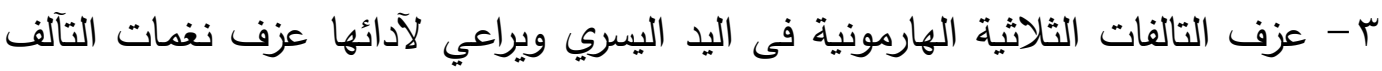

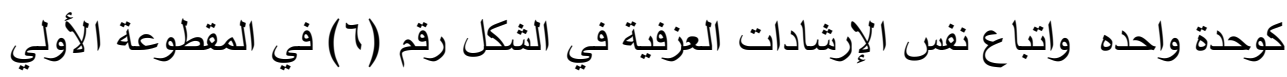

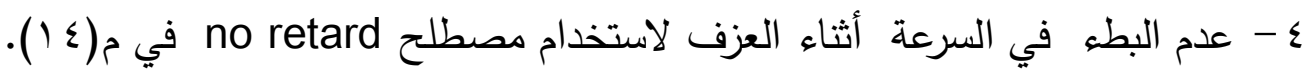
$(r \varepsilon)^{5}:{ }^{5}(1 \leq)$ من

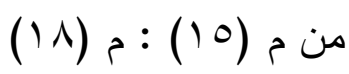
1 - آداء لحن سلمى صاعد وهابط بثكل متصل فى اليد اليمنى كما فى الثكل

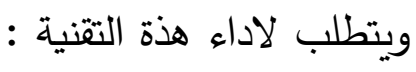
- تجنب العزف السطحى للنغمات السليمة حيث يكون العزف بعمق من الاصابع • - نقل الاصابع بسلاسة دون شد اليد والمحافظة علي اتصال اللحن لوجود أقواس لحنية.

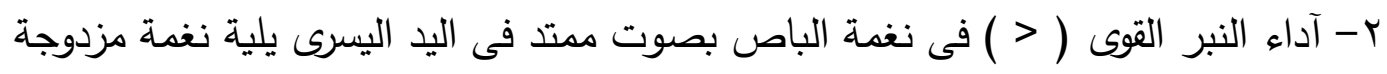

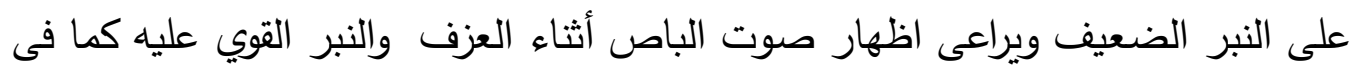
. (17)، (10)

مجلة علوم وفنون الموسيقى - كلية التربية الموسيقية ـ المجلد السابع والأربعون - يناير بr بrم 


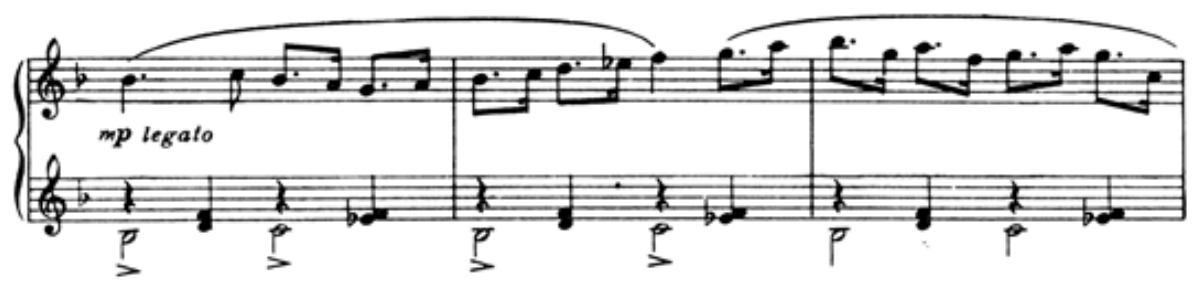

شكل رقم (זr) يوضح اللحن ا السلمي في اليد اليني والنبر القوي في اليد اليسري

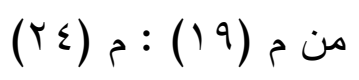

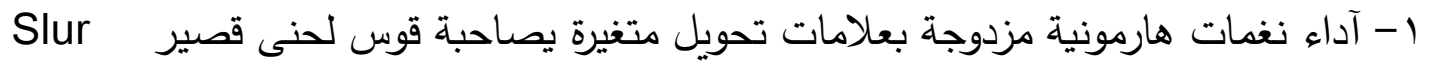

$$
\begin{aligned}
& \text { كما فى مازورة (YT) ، (Y) ( } \\
& \text { يتطلب ادائها : }
\end{aligned}
$$

- النبر القوى على النغتين فى اول القوس اللحن ثم العزف بشكل خافت على للنغمتين

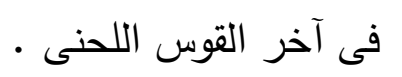

- مع مراعاه التركيز لتغيير علامات التحويل للنغمات والقفلة بصوت خافت بدون تبطئ

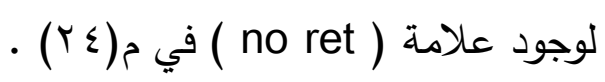

- العزف بقوة ثم التدرج الي العزف بشكل خافت لاستخدام علامة الديمينويندو

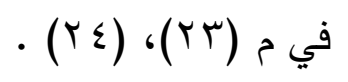

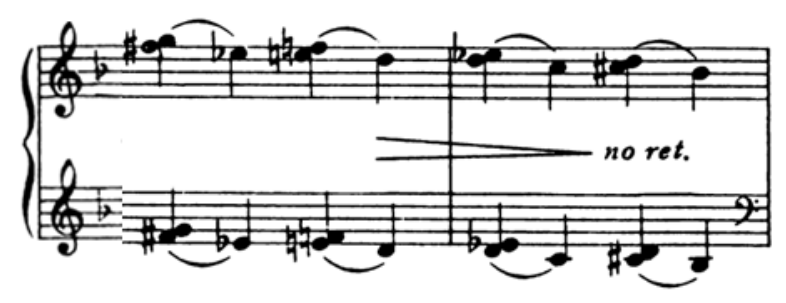

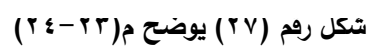

$$
\text { r) من م ro }
$$

- - تكرار طبق الاصل لجمل من الفكرة B،A ويراعى لآدائها اتباع نفس الارشادات السابقة .

$$
\text { من م (I) }
$$

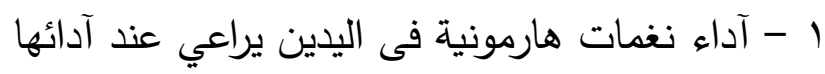

- آداء نغمات التآلف كنغمة واحدة وبنفس القوة مع مراعاة نفس الإشادادات اللحنية في

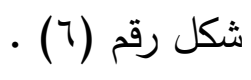

مجلة علوم وفنون الموسيقى - كلية التربية الموسيقية - المجلد السابع والأربعون - يناير بr مبام 
- مراعاه القوس اللحنى القصير Slur ، والرباط الزمني phrase والعزف بتأنى وبشكل أبطى للنهاية لوجود التعبير

gradually slower and more deliberate to the end .

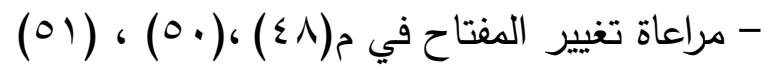

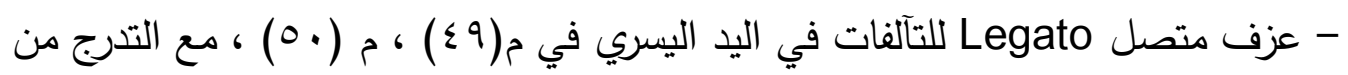
العزف الخافت إلي العزف القوي ثم العكس لاستخدام

- مراعاه الآداء المتقطع فى النغمات المفردة والمزدوجة والهارمونية فى اليدين وخصوصا مع وجود التعبير (P ) فى نهاية الكودا .

$$
\text { مقطوعة رقم }
$$

The sun lit glade

مقطوعة رقم r من البوم خيالات شبابية

Yocthfal fanneies

(تناسب الفرقة الثالثة)

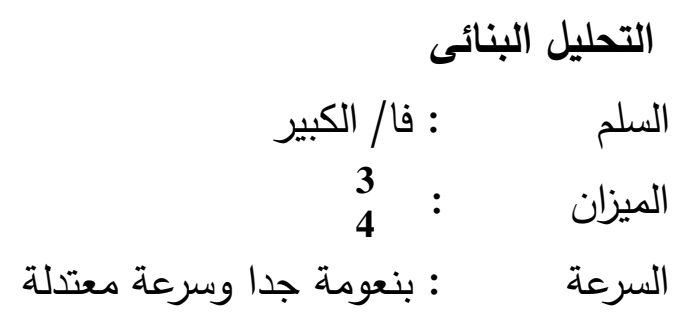

very delicately, and at agoood moving pace throughout

$$
\begin{aligned}
& \text { الطول البنائي : } \\
& \text { A-B-A } \\
& \text { القالب }
\end{aligned}
$$

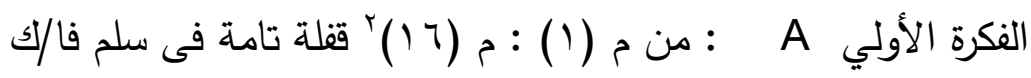

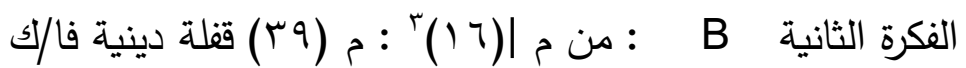

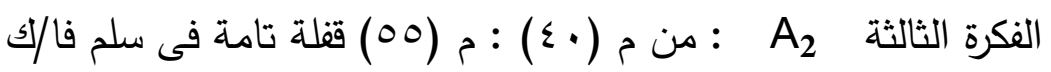

$$
\begin{aligned}
& \text { التحليـل العزفى }
\end{aligned}
$$


* اللحن والمصاحبة

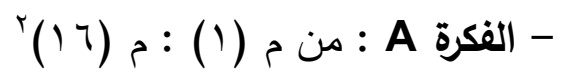

$$
\begin{aligned}
& \text { الجملة الأولي من م(1) : من م (1) : م (1) }
\end{aligned}
$$

جاء اللحن فى اليد اليمنى على شكل اداء متصل مل لنغمات سليمة هابطة وصاعدة مع قفزات مسافة الثالثة الصاعدة والهابطة علي نموذج إيقاعي متك ـ. . . . المصاحبة فى اليد اليسرى عبارة عن نغمتين مزدوجتين هارمونيا على مسافة الثانية متكرريتين

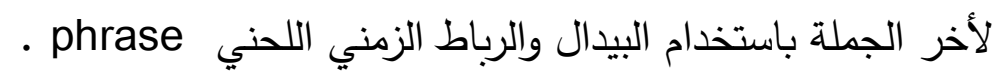

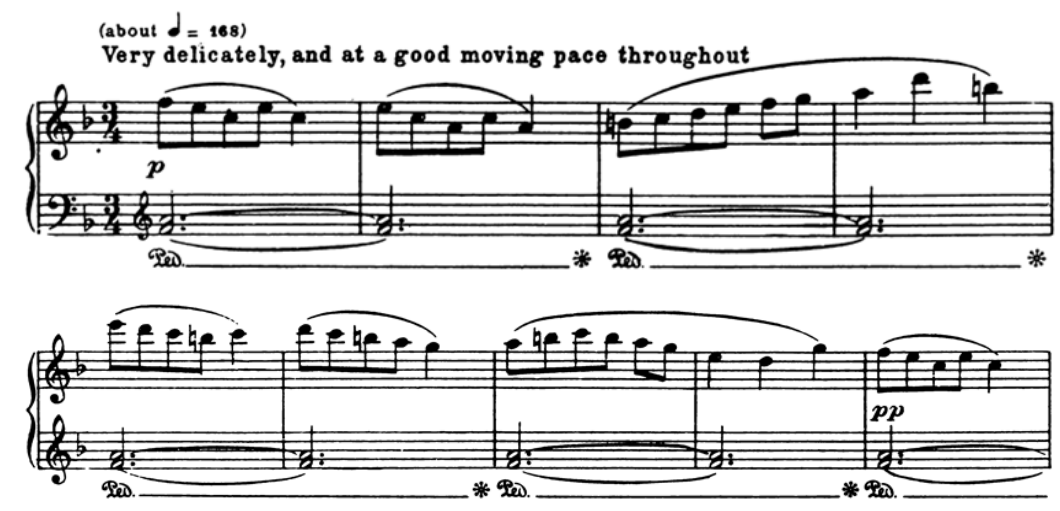

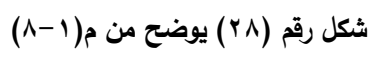

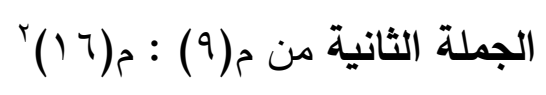

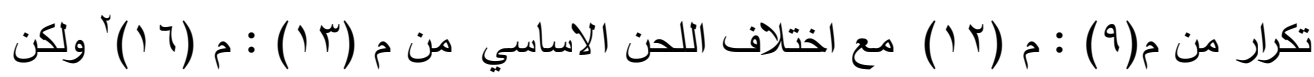

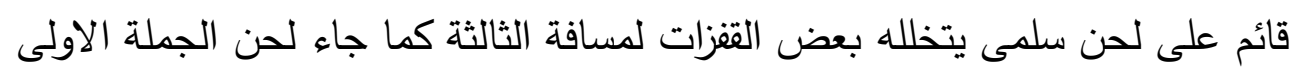

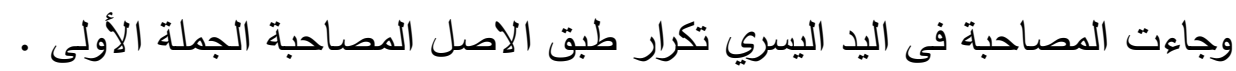

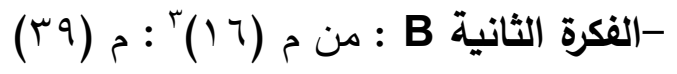

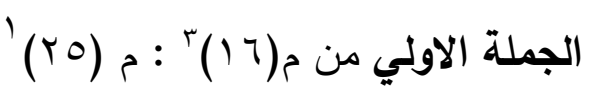

قائم على نموذج ايقاعي متكرر ولكن مع بعض التغيرات فى اليد اليسري ، جاء اللحن

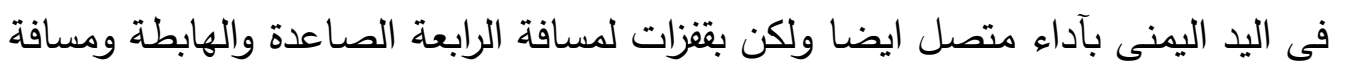
الثالثة الهابطة والصاعدة مع النغمات السليمة ، وجاءت المصاحبة فى اليد اليسرى عبارة

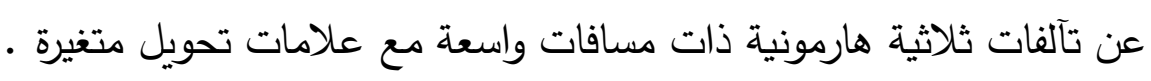

مجلة علوم وفنون الموسيقى ـ كلية التربية الموسيقية - المجلد السابع والأربعون - يناير بr بrم 


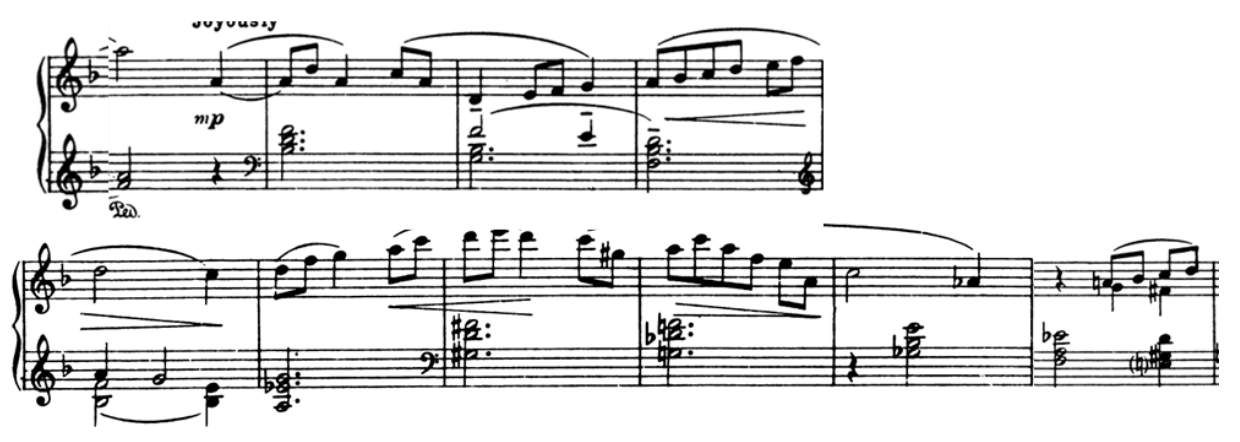

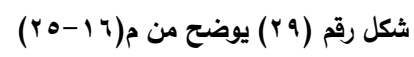

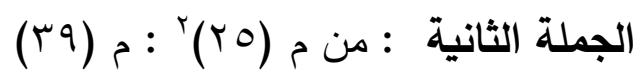

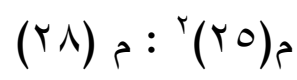

عبارة لحنية مكثفة حيث جاء لحن صوت السوبرانو سلمى صاعد وهابط مع وجود قفزات على مسافة الثالثة و الرابعة الصاعدة والهابطة وصوت دالثة داخلى بلحن كروماتى هابط يدعم نغمات

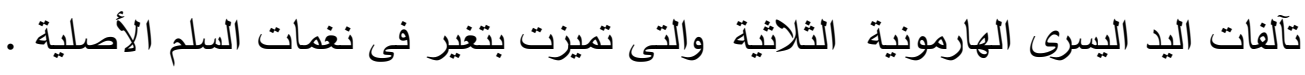

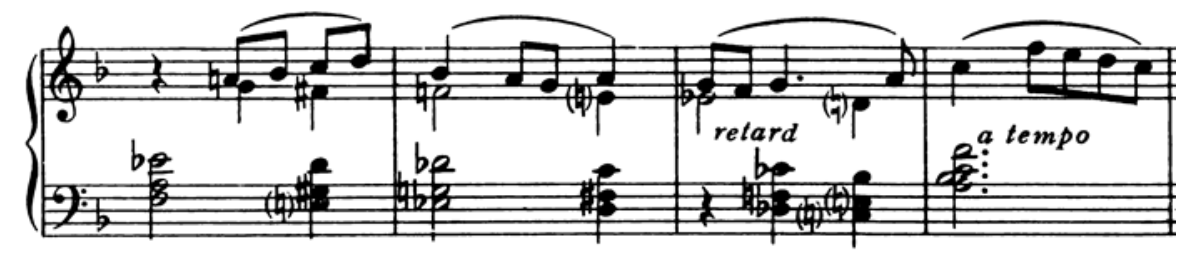

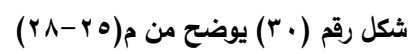

$\left.(r 0)^{5}:(r q)^{5}\right)^{5}$

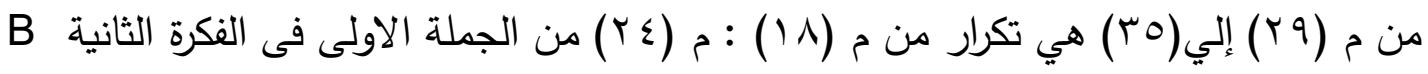

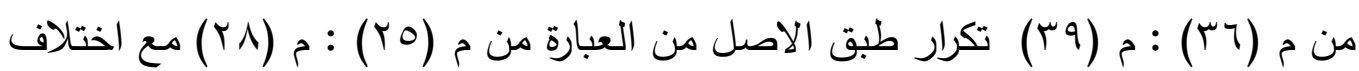
فى لحن م (q) من مهيدا للفكرة الثالثه

- الفكرة الثالثة A2 : من م (• ع) : م (00) هي تكرار طبق الأصل للفكرة الأولي A

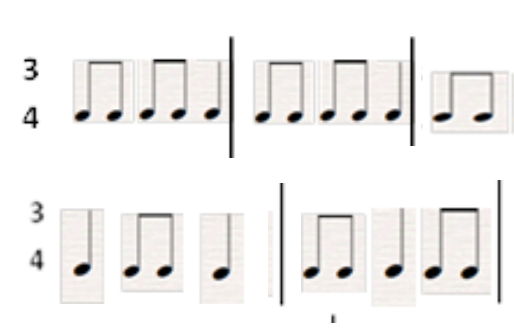

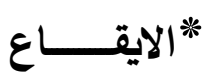
نماذج اليد اليمني

مجلة علوم وفنون الموسيقى - كلية التربية الموسيقية - المجلد السابع والأربعون - يناير بr +rم 770 

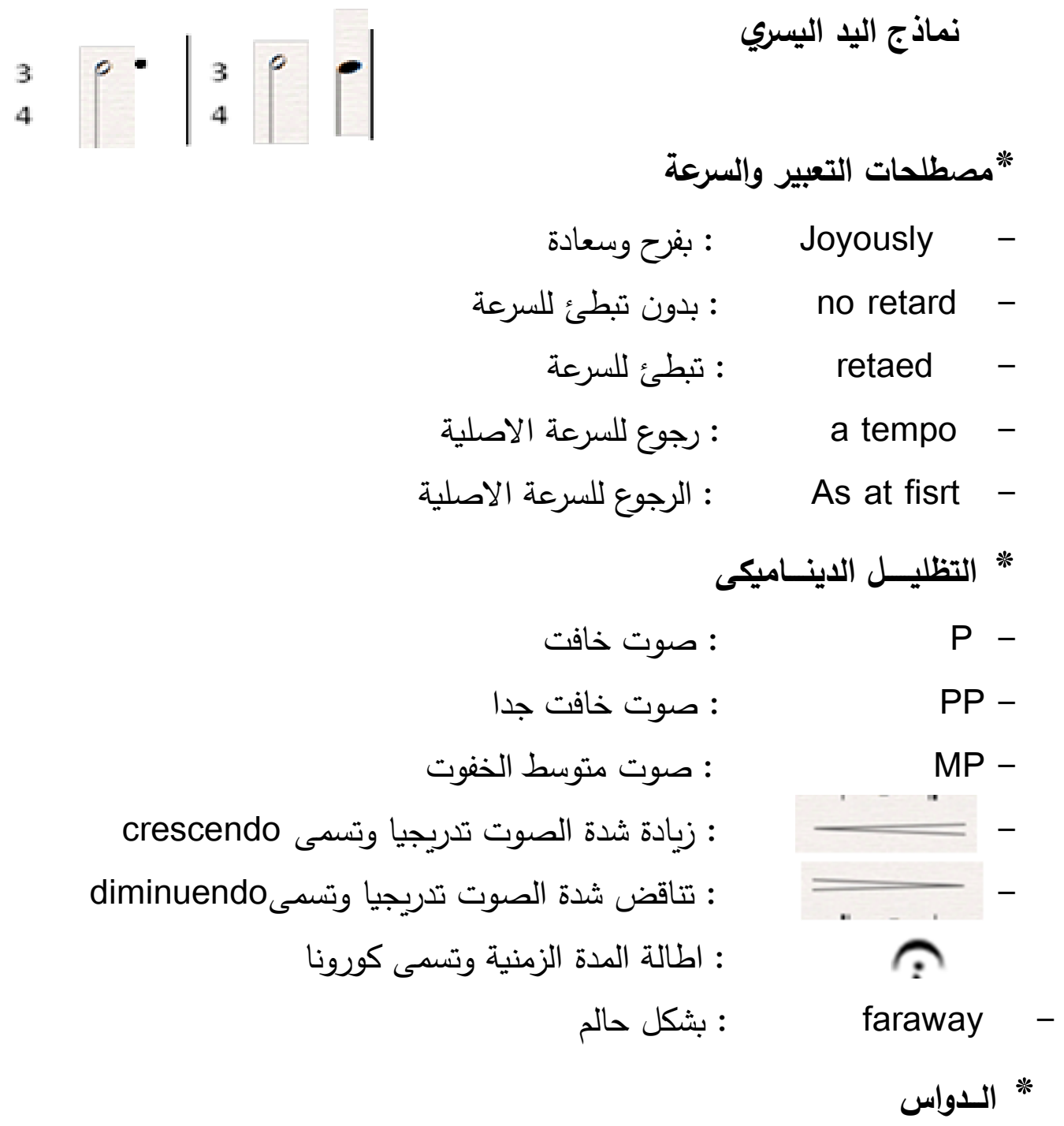

استخدام الدواس فى الفكرة A الأولي كاملة والفكرة الثالثة A كاملة ولم يستخدم فى

الفكرة الثانية B

$$
\text { * لا لا توجد }
$$

* التفنيات العزفية ومتطلبات ادائها

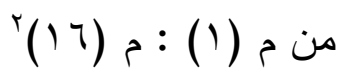

1- آداء نغمات سلمية صاعدة وهابطة مع قفزات مسافة ثالثة صاعدة وهابطة بعزف متصل

$$
\text { ويتطلب لآدائها : }
$$

- تجنب العزف السطحى أى يكون العزف بعمق من الأصابع ونقل الأصابع بسلاسة 


$$
\text { لاعطاء الاحساس بعدم تقيد الاصابع · }
$$

- عدم الفصل بين النغمات ورفع اليد بخفة فى نهاية القوس اللحني (الرباط الزمني) للحفاظ

$$
\text { - علي العزف المتصل • }
$$

- الإلتزام بعد البطء في السرعة لاستخدام مصطلح no retard -

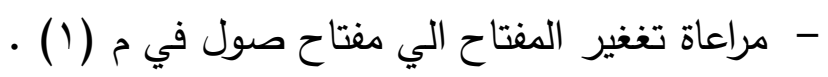

r - آداء نغمات هارمونية مزدوجة على مسافة الثالثة فى اليد اليسرى مع استخدام الدواس

$$
\text { - ميتطلب لآدائها : عزف النغتين بقوة لمس واحدة }
$$

- مراعاة الرباط الزمني phrase في اليد اليسري والذي يمتد الي مازورتين متتاليتين .

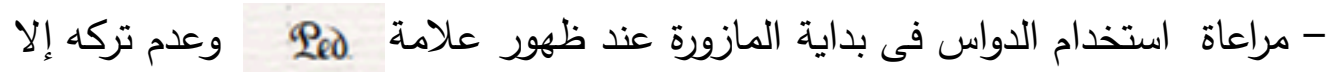

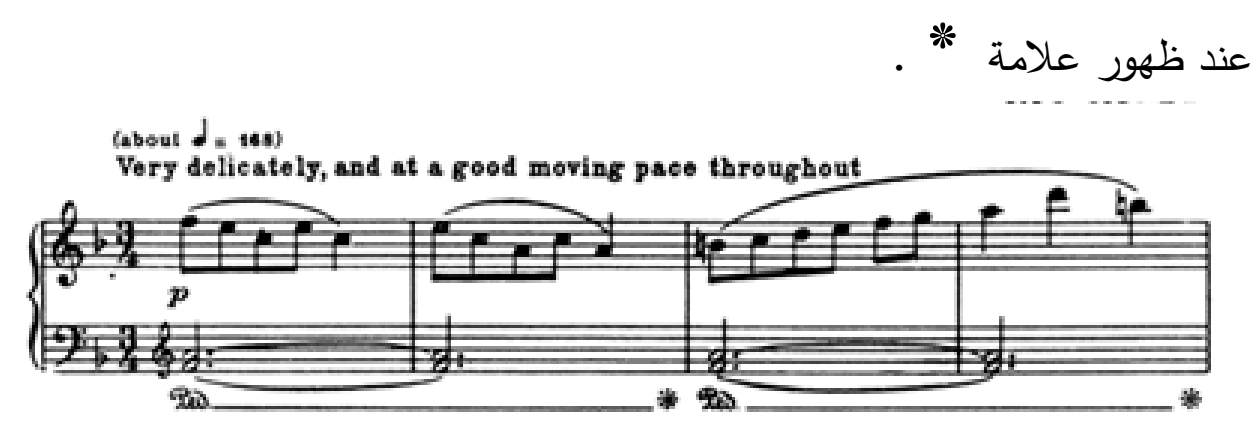

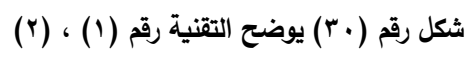

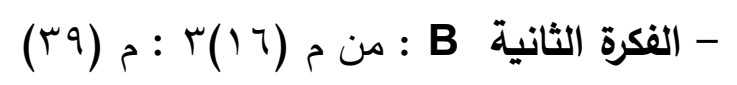

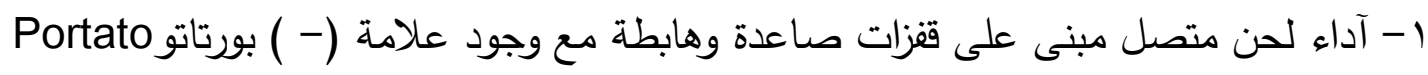

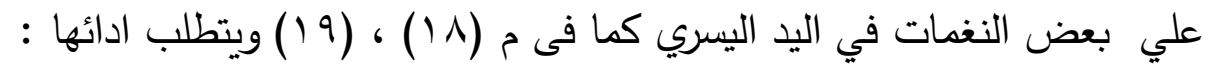

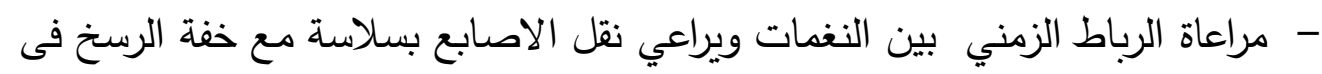

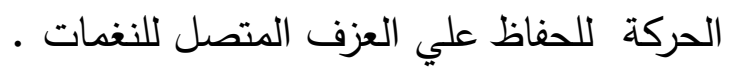

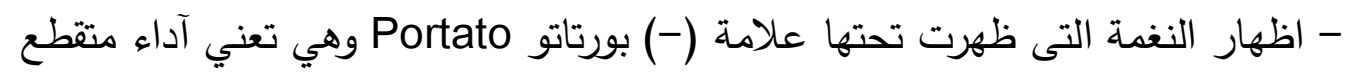

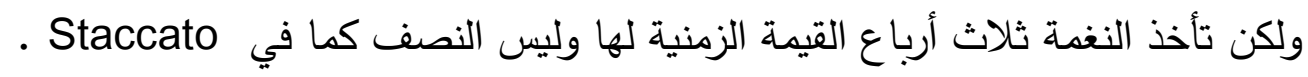

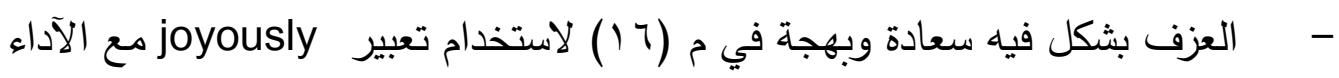
متوسط القوة لاستخدام (mp) (

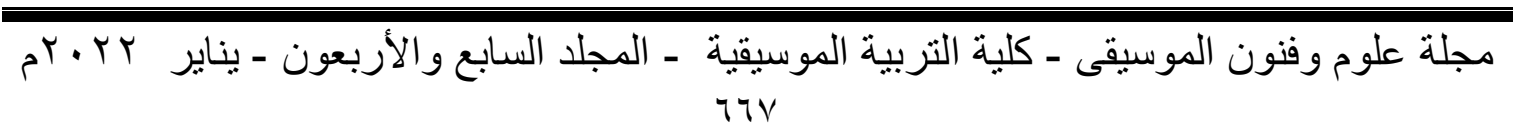


a tempo ثراعاة البطء في العزف في م(retard (rV (العودة للسرعة الأصلية

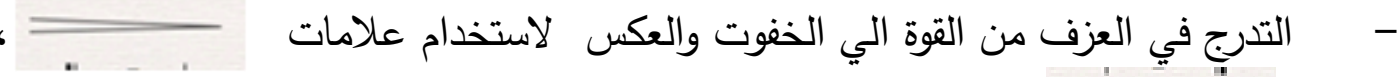

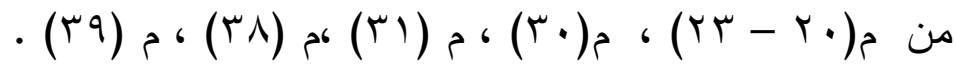

r - آداء تالفات هارمونية ثلاثية فى اليد اليسرى ويتطلب ادائها :

- تئدى نغمات التآلف كوحدة واحدة بقوة متساوية بحيث لايطغي صوت احدى النغمات

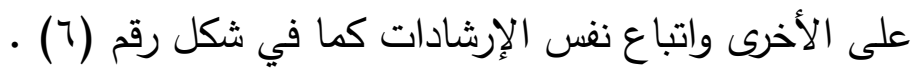

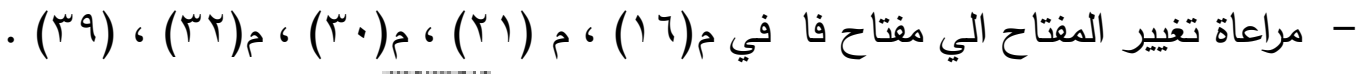

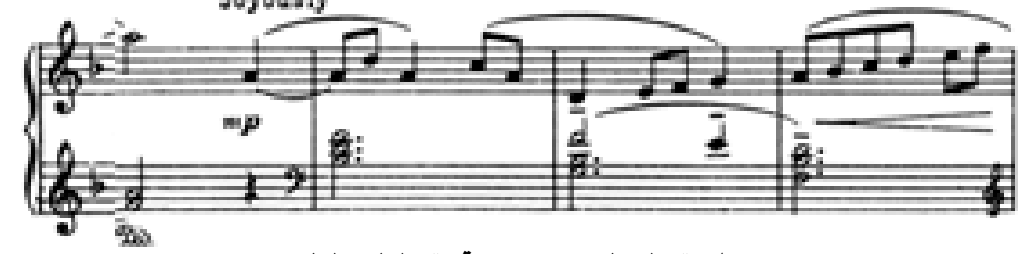

شكل رقم (آץ) يوضح التقنية رقم (1) ، (ץ)

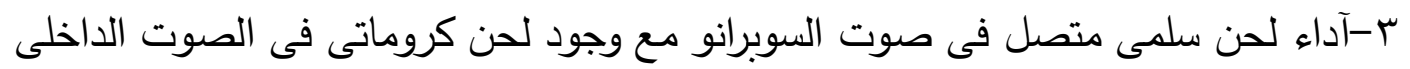

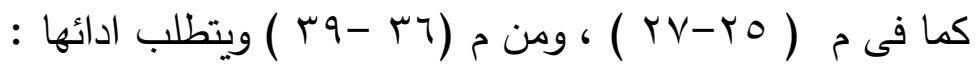

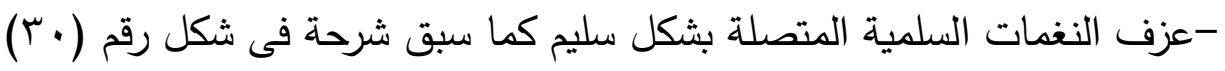
- اظهار اللحن الكروماتى فى الصوت الداخلى بشكل متصل .

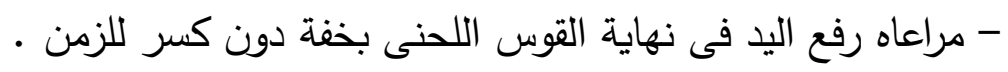

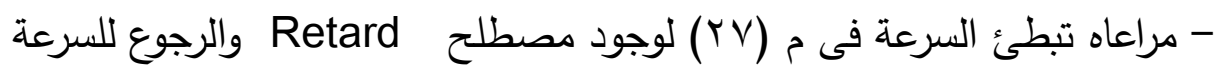

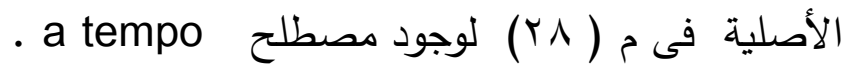

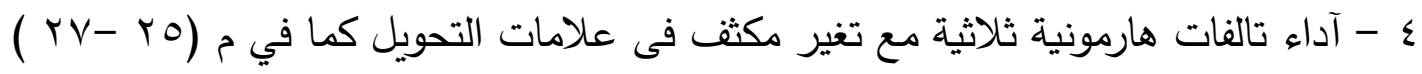
ويتطلب ادائها :

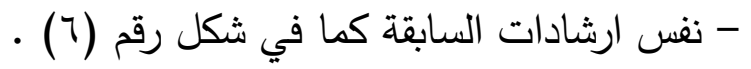

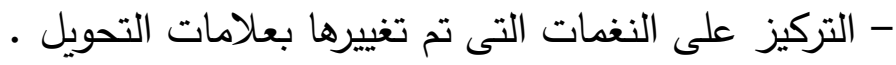

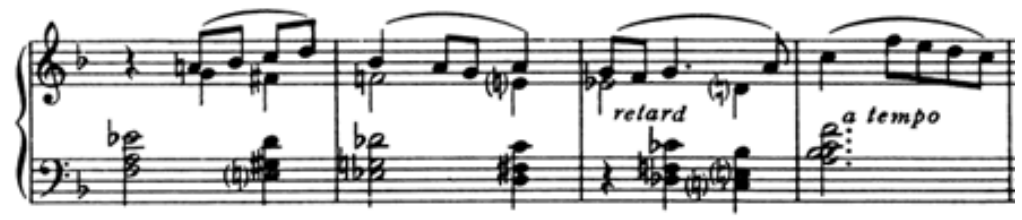

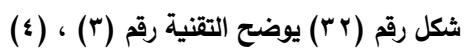

الفكرة الثالثة A2 : من م (• أك) إلي م (00) تكرار طبق الأصل للفكرة الأولي A2 ويراعي فيها تطبيق نفس الإرشادات العزفية .

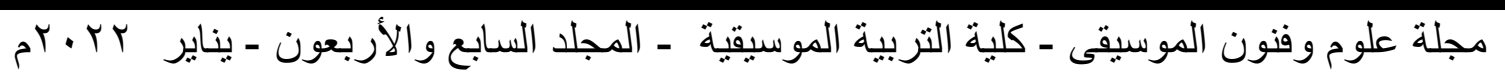




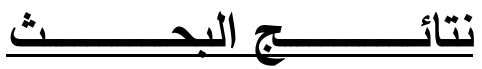

بعد أن قامت الباحثة بالدراسة التحليلية العزفية لبعض مقطوعات البيانو عينة البحث للمؤلف

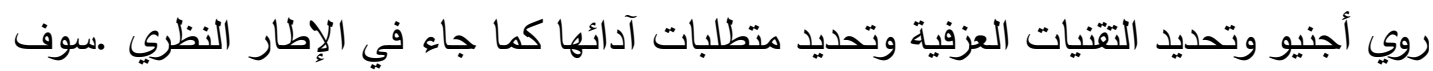
تقوم الباحثة بالإجابة علي أسئلة البحث علي النحو التالي :

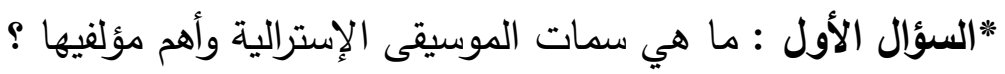

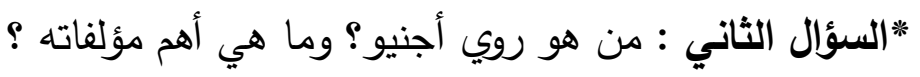
قامت الباحثة بالإجابة علي السؤالين من خلال تتاولها الموسيقي في الاسترالية والسيرة الذاتية للمؤلف روي أجنيو وأهم أعماله للبيانو

السؤال الثالث : ماهي الصعوبات العزفية في مقطوعات البيانو عند روي اجنيو ومتطلبات آدائها؟

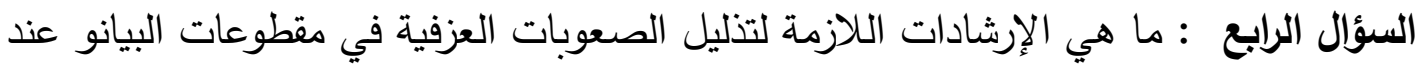

روي اجنيو ومتطلبات آدائها؟

قامت الباحثة بالإجابه عليهما في الإطار التطبيقي من خلال التحليل البنائي والعزفي لمقطوعات عينة البحث وتحديد التقنيات العزفية وتوضيح دنطلبات آدائها ، وقد توصلت الباحثة الإنة

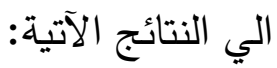

- - استخدم المؤلف سلم أساسي في المقطوعة ولكنه استخدم علامات تحويل بكثر يلمس بها

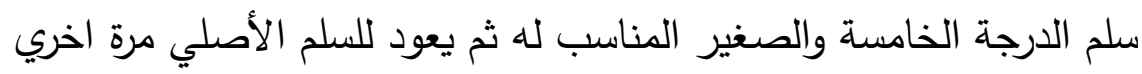
- - استخدم ميزان واحد طوال المقطوعة ولم يستخدم تغيير الموازين باستثناء المقطوعة رقم

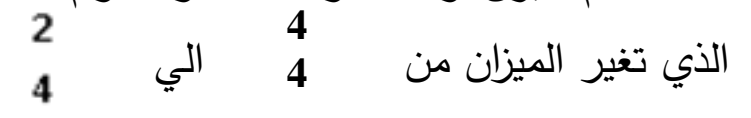

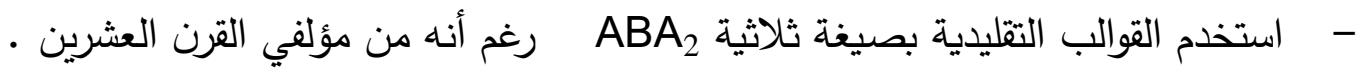
- - - - عن السرعة بالكلمات التي تعبر عن حالة السرعة وليس تحديد السرعة بشكل دقيق.

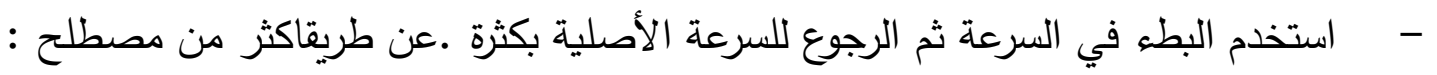

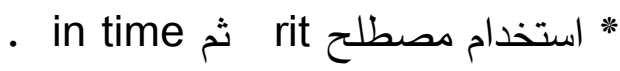
* استخدام البطء في السرعة a little slower ثم الرجوع إلي السرعة الأصلية عن in time مصطلح

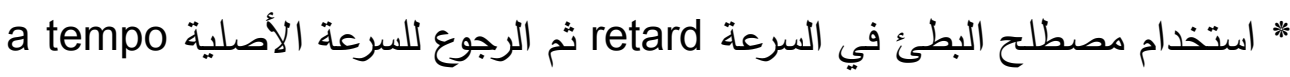

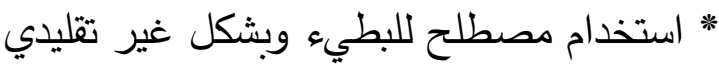

مجلة علوم وفنون الموسيقى - كلية التربية الموسيقية - المجلد السابع والأربعون - يناير بr ·r م 
Gradually slower and more deliberate to the end

ويعني عزف بشكل أبطئ وبتآني إلى النهاية .

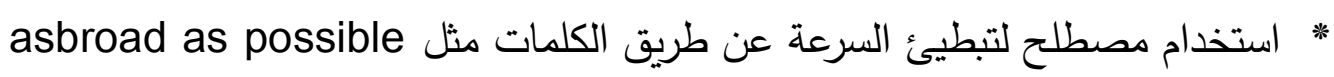

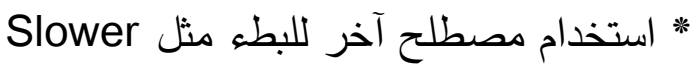

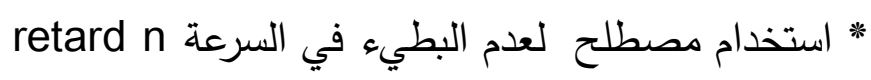

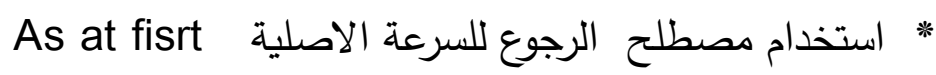

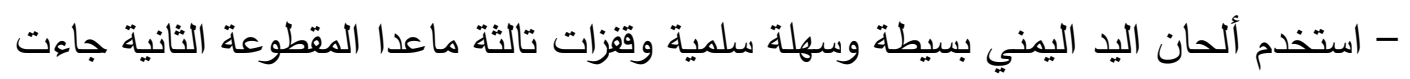
تآلفات كثيفة هارمونية معبرة عن طابع الدقطوعة. بينماجاءت ألحان اليد اليسري كلهاعبارة

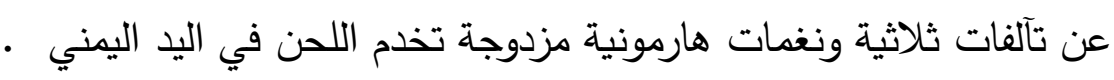
- استخدم مصطلحات التظليل الديناميكي بكثرة:

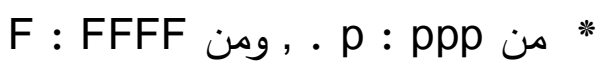

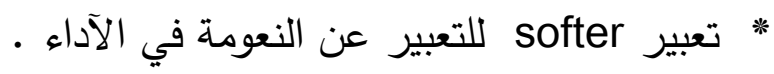

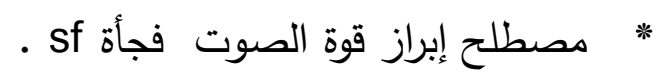

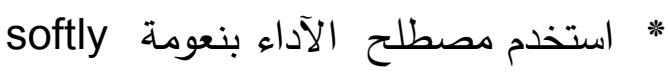

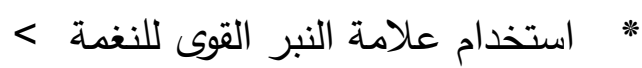

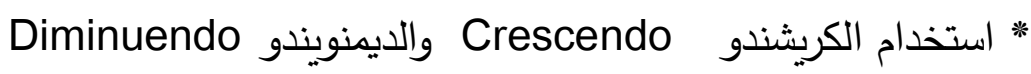
- استخدم نماذج إيقاعية بسيطة ولم يستخدم أي مقابلات إيقاعية أو اي إيقاعات شاذة

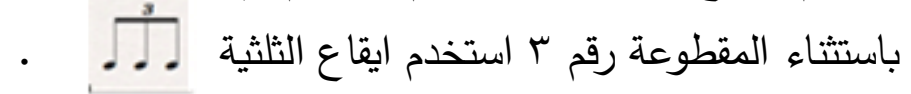

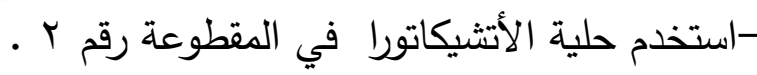

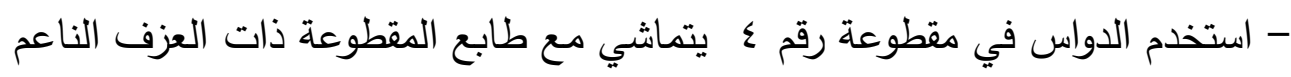

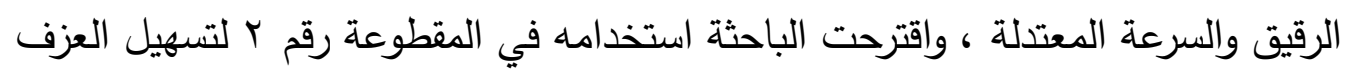

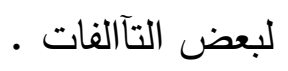
- استخدم تغيير الsفاتيح من مفتاح صول الي مفتاح فا في جميع المقطوعات .

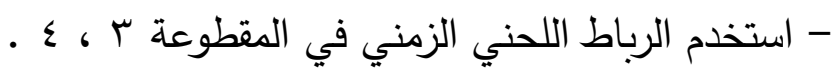

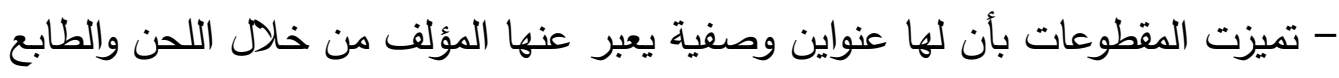

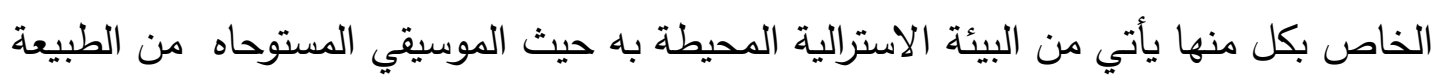

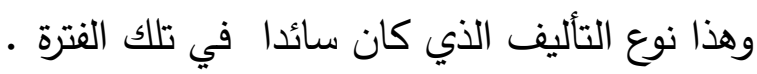

مجلة علوم وفنون الموسيقى - كلية التربية الموسيقية - المجلد السابع والأربعون - يناير بr. •rم 


\section{توصيــــــات البحــــــث}

1- توفير مؤلفات البيانو عند روي أجنيو لتوسيع دائرة الإختيار للمقطوعات الحرة في القرن

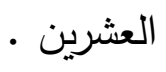
r- الإستفادة من مقطوعات روي أجنيو في مناهج مرحلة البكالريوس ومحاولة وضعها ضمن

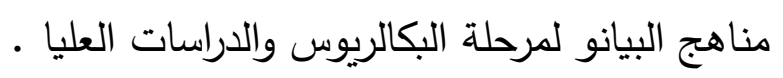

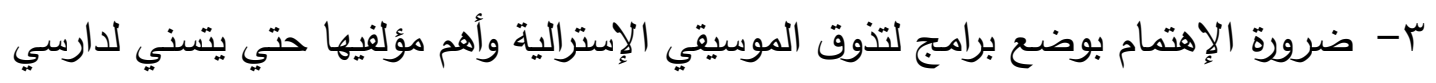

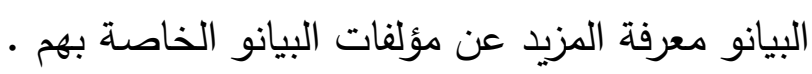
ع - تنظيم مسابقات لعزف مقطوعات روي أجنيو . 


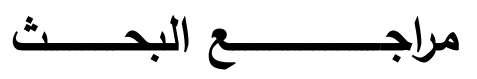

\section{المراجع العربية}

1- امال صادق ،فؤاد أبو حطب -"مناهج البحث وطرق التحليل الإحصائي" مكتبة الأنجلو

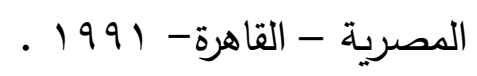

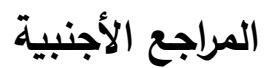

2) Agay Dense: "Teaching piano" Hamilton Printing company Vol.1, New York, 1981.

3) Latham, Alison: "The Oxford Companion to Music", Oxford Universisty press, 1938.

4) Randel, D. Michael: "The Harvarrd Concise Dictionary of music and musician", Harvarrd Collge,USA, 1999 .

5) Sadie, Stanly: "The Grove Concise Dictionary of Music", Oxford University Press, 1988.

6) Sadie, Stanly: "The New Grove Dictionary of Music and Musicians" ${ }^{\text {th }}$ Edition,Vol, ,Oxford Universisty press, 2001.

7) Serle, Geoffrey and : Bede, Nairn :" Australian Dictionary of Biography", vol:7 , Melbourne University press , 1891-1939. A-ch 8) Sitsky, Larry: Australian chamber music with piano,Published by ANU E Press, The Australian National University, Canberra ACT 0200, Australia,2011.

9) Sitsky, Larry: Australian Piano Music of The 20 th Century, Library of Congress Cataloging-in-Publication Data,2005 .

10) http://themusichistory.com/australia-music-history.html.

11) http://www.australian-information-stories.com/music-ofaustralia.html. :

https://britishmusiccollection.org.uk/composer/roy-agnew,

12) http://www.Slideshare.net/violapond87/the-history-of-australain-music

13) https://britishmusiccollection.org.uk/composer/roy-agnew

14) https://musicaustralia.org.au/discover/the-professional-musicindustry/music-in-australia.

15) https://www.austraianmusiccentr.com-au/artist/agnew-roy.

مجلة علوم وفنون الموسيقى - كلية التربية الموسيقية - المجلد السابع والأربعون - يناير بr ·r م 


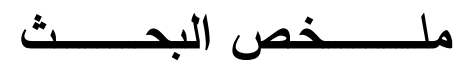

متطلبات أداء مقطوعات البيانو في أستراليا عند روي أجنيو Roy Agnew

\section{مقدمة البحث}

كان استخدام الموسيقي الإسترالية مقتصراً علي استخدام الآلات القديمة في حفلات الزواج إلي أن استطاع السكان الأصليون دمج أصواتها مع الآلات الموسيقية التقليدية والوصول في الترن الثامن عشر إلي تراث من قوالب التأليف المعروفة في عصر الباروك والعصر الكلاسيكي والرومانتيكي والموسيقي المعاصرة .

اتجه الموسيقيون والمؤلفون مع زيادة الوعي الوطني القومي إلي استخدام ألحان وإيقاعات

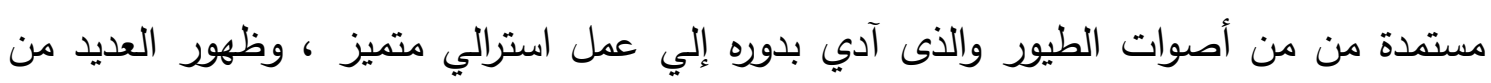

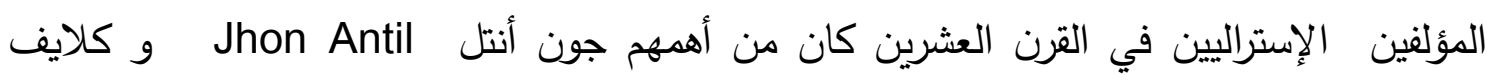
دوجلاس Clive Douglas ، وروي أجنيو Roy Agnew ، الذي سوف يتناوله البحث بالدراسة والتحليل نظرا لتراثه الموسيقي المتتوع • وقد اختارت الباحثة أربعة مقطوعات من ألبومين مختلفين

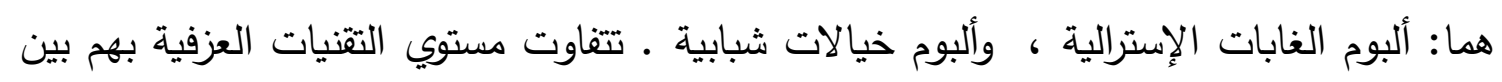
السهولة والصعوبة .

ويشتمل البحث علي المقدمه - مشكلة البحث - أهداف البحث - أهمية البحث - أسئلة البحث - إجراءات البحث .

وينقسم البحث إلي جزئين :

الجزء الأول

نبذة مختصرة عن الموسيقي الإسترالية

حياة المؤلف روي أجنيو ومؤلفاته للبيانو

الجزء الثاني

الإطار التطبيقي ويشتمل علي دراسة تحليلية عزفية لأربع مقطوعات من ألبومين مختلفين.

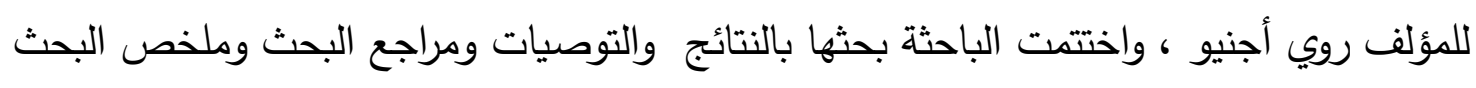
باللغة العربية والإنجليزية والمدونات الموسيقية لعينة البحث.

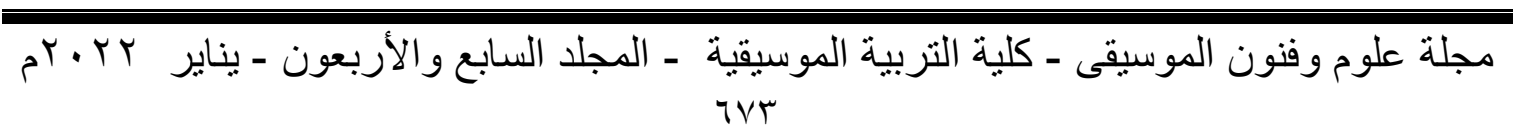




\section{Abstract of the Research Performance Requirements of Australian Piano Pieces by Roy Agnew}

\section{Introduction of the research}

The use of Australian music was limited to the use of old instruments in wedding ceremonies until the indigenous people were able to combine its sounds with traditional musical instruments and in the eighteenth century access to a heritage of compositions known in the Baroque era, the classical era, the romantic era and contemporary music..

Musicians and composers tended with increasing national awareness to use melodies and rhythms derived from the sounds of birds, which in turn led to a distinct Australian work, and the emergence of many Australian composers in the twentieth century, the most important of which were Jhon Antil, Clive Douglas, and Roy Agnew, who The research will study and analyze due to his diverse musical heritage. The researcher chose four tracks from two different albums: the Australian Forest Album, and the Youth Fantasies album. The level of their playing techniques varies between ease and difficulty.

The research includes the introduction, the research problem, the research objectives, the importance of the research, the research questions, and the research procedures.

The research is divided into two parts:

\section{Part One :}

- A brief introduction to Australian music

- The life of author Roy Agnew and his compositions for piano .

\section{Part Two :}

The applied framework includes an analytical study of the playing of four tracks from two different albums for the author Roy Agnew, and the researcher concluded her research with results, recommendations, research references and research summary in Arabic, English and music notations for the research sample.

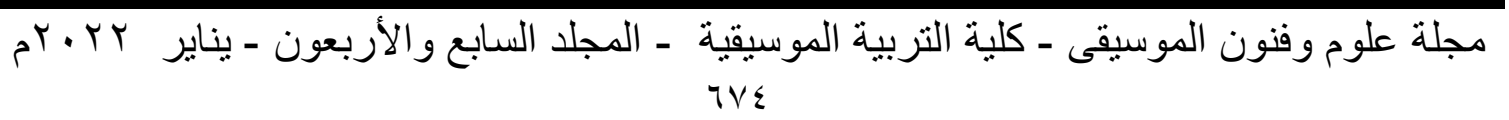

